\title{
The human-dimensions ecology of parrots reintroduced to a city: the Kākā (Nestor meridionalis) of Wellington, New Zealand.
}

\author{
Johan Matthys Gouws
}

\author{
A thesis submitted to \\ Victoria University of Wellington \\ in partial fulfilment of the requirements for the degree of \\ Master of Science in Conservation Biology.
}

2019

VICTORIA UNIVERSITY OF WELLINGTON

Te Whare Wānanga o te Ūpoko o te Ika a Māui

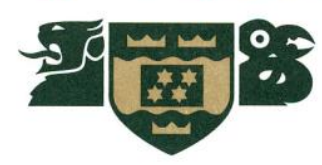





\section{Abstract}

Conflict involving wildlife and people is globally common and is one of the more difficult challenges facing conservation. The increasing trend for wildlife to colonise, or be reintroduced, to cities increases the chances of conflict occurring. It is common for people to feed wildlife which leads to an increase in their local density. This concentrates their odours, fouling, noise, nesting, property damage and in some cases, can lead to attacks on people. Wherever they have been measured, attitudes to wildlife are generally positive and robust to some damage and conflict. Nonetheless, more negative attitudes and conflict among residents are particularly likely if the wildlife impose an economic cost. Understanding how wildlife use urban environments, what influences their habitat choices in cities, particularly their relationships with people (e.g., feeding), and how these could lead to conflict and deteriorating relationships with wildlife is essential for planning future reintroductions and preventing or mitigating conflict over wildlife in cities.

Kākā (Nestor meridionalis) were reintroduced to Wellington City in 2002 and they are now commonly seen in city suburbs around the reintroduction site. The number and range of kākā appears to be increasing, as are reports of damage by kākā to public and private property. Most people report positive attitudes towards kākā, and some residents intentionally feed them. At these feeders, kākā appear to congregate in larger numbers. Recent research suggests that kākā feeding and damage may be initiating a conflict among residents, especially between neighbours who do and do not feed kākā. This can lead to deteriorating attitudes towards kākā, and native wildlife and conservation generally.

The aims of this thesis are to better understand 1) which factors affect the presence of kākā on residential properties, 2) which factors lead to or exacerbate damage to these properties and 3) how damage affects resident attitudes towards kākā and avifauna conservation in general. I hypothesized that kākā will be in greater densities in areas proximal 
to native vegetation and close to their 2002 reintroduction site. I further predicted that the damage to properties will be more common and at a greater extent at sites where more people feed kākā. As this damage increases, it will negatively impact resident attitudes, especially where the damage imposes a cost on the resident.

A postal survey sent to 600 residences at 25 stratified random sites (neighbourhoods) across Wellington City suburbs was used to quantify residents' self-reports of kākā on properties, residential feeding activity, property damage and their attitudes to kākā and avian wildlife. A total of 309 surveys were returned (52\%) with 301 entirely complete and used in the final analysis. The sites were also visited to quantify their environments, particularly topographical exposure, tree size and the number of emergent trees that were hypothesised, from my anecdotal observations and the literature, to potentially be important influences on kākā distribution. An information theoretic approach was used to test current hypotheses (models) for kākā abundance on properties and property damage by compiling a candidate set of 46 models for kākā abundance and 22 for kākā damage. A repeated measures, one-way ANOVA tests was used to determine if damage negatively affected resident attitudes.

Residential feeding was found to be the strongest driver of kākā presence, followed by the proximity of native vegetation. The abundance of kākā, particularly the frequency with which kākā visit properties, was found to be the best explanatory variable for the presence and scale of property damage. Damage itself was not found to be a significant driver of increasingly negative attitudes. However, the few residents spending greater than $\$ 50$ to repair damage showed significantly lower attitude scores compared to those that had no expenditures.

Overall, resident attitudes towards the kākā in Wellington are generally positive. However, these findings suggest that there is a causative pathway leading from residential feeding of kākā to occurrences of increasingly negative attitudes and conflict among neighbours that are sensitive to the economic cost of damage. While conflict between people 
and kākā in Wellington is certainly present, it is not yet widespread. However, it is likely that instances of conflict involving kākā and people will only grow as the kākā population within the city continues to increase. There is a need to seek solutions to mitigate this conflict promptly, before it reaches a tipping point in which widespread negative attitudes will be difficult to change. Financial compensation and the discouraging of feeding are discussed as recommended solutions, tailored to findings in this thesis. 
"Conservation is a state of harmony between men and land." -Aldo Leopold 


\section{Acknowledgements}

Firstly, I'd like to thank my supervisor Dr.Wayne Linklater. Thank you for your guidance over the last two and a half years, both inside and outside of the classroom. Thank you for the encouragement, the countless re-reads of chapter versions and helping me develop these ideas that now at last, have found their way to paper. Especially during your time overseas on break and sabbatical.

A big thanks goes to my family. My mother for helping me with the initial drop offs of the introduction letters. My father for helping me with site visits and environmental measuring. Most of those streets are definitely not exactly wheelchair friendly! Thank you for your help with the seemingly endless amount of folding, stuffing and labelling of envelopes. It definitely would not have gone as well as it did without your physical and verbal support. My brother, Jacques and the rest of my friends. There were definitely times where you kept my head level and sane even if you didn't realise it, so thank you too.

Thank you to the Centre for Biodiversity and Restoration Ecology, particularly Mr. David Day for funding the project grant I was awarded. It allowed me to purchase the many supplies that were needed for this study.

I'd also like to acknowledge and thank the VUW Disability Services, especially Joanna Clover for their support over the years. Although you had no direct input in this thesis, you helped me immensely through my undergraduate degree, for me to get to this point.

Lastly, but not least, a big thank you to the Wellington public. This research could not have been done without those that responded to the surveys and the time they took to out of their day to so. 


\section{List of Tables}

Table 2.1: Fixed effect variables chosen to test for effect on kākā abundance, visiting frequency and group size with measurement methods, means ( $\pm 1 \mathrm{SE})$, maximum and minimum values

Table 2.2: A priori hypotheses and models of AIC model tests for overall abundance, visiting frequency and visiting group size.....................................................

Table 2.3: The candidate set of 48 linear mixed-effect models as hypotheses for the drivers of resource selection at urban residences by total kākā abundance, reported by Wellington City residents on their properties.....................................................

Table 2.4: The candidate set of 48 linear mixed-effect models as hypotheses for the drivers of resource selection by kākā visiting frequency, reported by Wellington City residents on their properties.

Table 2.5: The candidate set of 48 linear mixed-effect models as hypotheses for the drivers of resource selection by visiting group size of kākā, reported by Wellington City residents on their properties.

Table 3.1: Table of hypotheses explaining kākā damage on residential properties with candidate set of 22 models.

Table 3.2: The candidate set of 22 linear mixed-effect models as hypotheses for the drivers of the presence of kākā damage reported by Wellington City residents on their properties...66

Table 3.3: The candidate set of 22 linear mixed-effect models as hypotheses for the drivers of total kākā damage reported by Wellington City residents on their properties....

Table 3.4: The candidate set of 3 linear mixed-effect models as hypotheses for the suitability of random-effects, SiteID and ResID.....

Table 3.5: The candidate set of three linear mixed-effect models for testing whether factors driving damage better explained attitudes than aspects of damage itself. 


\section{List of Figures}

Figure 1.1: Map of Wellington City showing study sites in Wellington City. Sites receiving normal surveys indicated in light grey, sites receiving alternate survey are indicated in black. Karori Wildlife Sanctuary is outlined in white...................................... 15

Figure 2.1: Mean kākā abundance ( $\pm 1 \mathrm{SE}$ ) at sites with increasing numbers of residents who feed kākā on their properties. Feeders per site predictor was present in the top four models, for a summed weight of 0.718 . Kākā abundance increased as the number of feeders per site

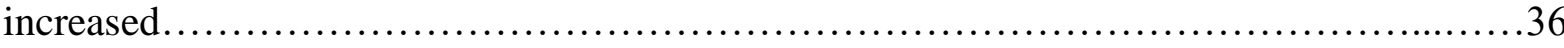

Figure 2.2: Mean kākā abundance at the 25 sites in response to the distance from KWS and the number of residential feeders per site. Markers indicate feeder number; diamonds $=$ no feeders, squares $=1$ feeder, triangles $=2$ feeders and circles $=5+$ feeders $\ldots \ldots \ldots \ldots \ldots \ldots 37$

Figure 2.3: Mean kākā abundance across the 25 study sites in response to urban density. Urban density is portrayed in this context as a measurement of mean lot size of a site......38

Figure 3.1: Mean damage scores $( \pm 1 \mathrm{SE})$ reported by residents in response to kākā visiting frequency and group size (black bar: 1 to 3 kākā, white bar: 4 to 9, grey bar: 10+). Damage is scored from 4 sources: roofing, other building surfaces, trees, and miscellaneous other.....69

Figure 3.2: Mean Likert scores $( \pm 1 \mathrm{SE})$ to the seven attitude statements from the surveys in which responses to attitude statements occurred before or after questions about kākā abundance and damage to resident's property.......................................... 72

Figure 3.3: Mean sum of Likert scores ( \pm 1 SE) from seven attitude statements by respondents who report feeding or not feeding kākā given the order of attitude and kākā abundance and damage questions in the survey they answered

Figure 3.4: Mean Likert scores $( \pm 1 \mathrm{SE})$ to the seven attitude statements from the surveys which compared responses from feeders to those of non-feeders....

Figure 3.5: Mean summed attitude scores $( \pm 1 \mathrm{SE})$ from residents who spent varying degrees of financial cost to repair damage to their property by kākā...........................77

Figure 3.6: Mean Likert scores $( \pm 1 \mathrm{SE})$ to the seven attitude statements from the surveys which compared responses from residents who spent varying degrees of financial cost to

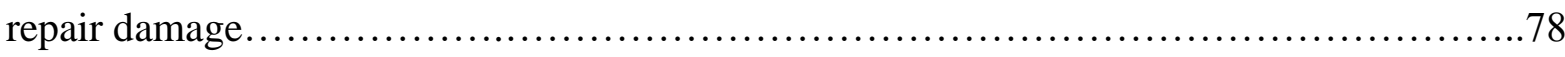

Figure 4.1: General pathway of kākā-resident interaction in Wellington City, from residential feeding and kākā abundance to resident attitudes. 


\section{Contents}

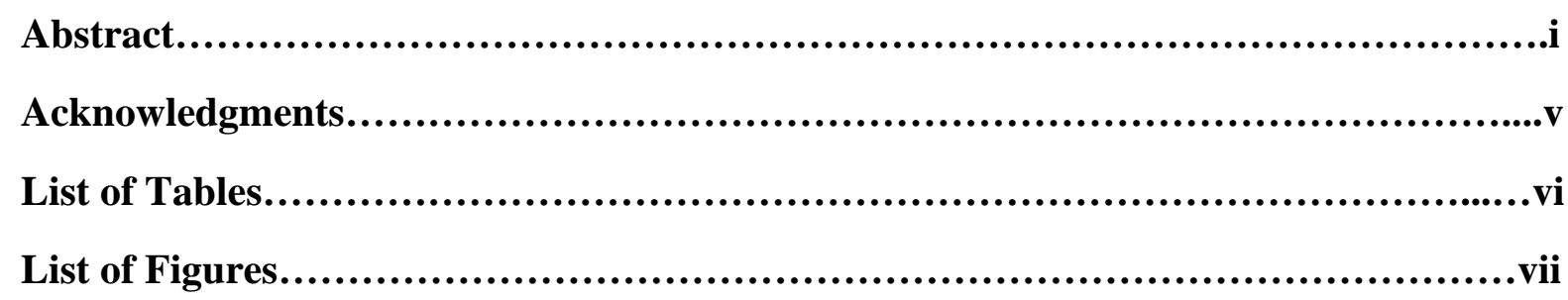

Chapter One: General Introduction.....................................................1

1.1. Urbanisation and pressure on the natural environment................................

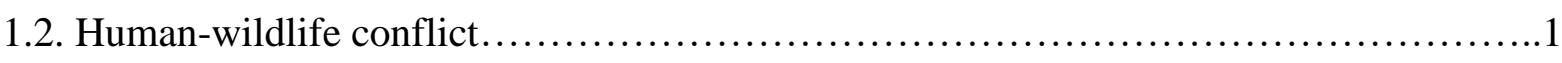

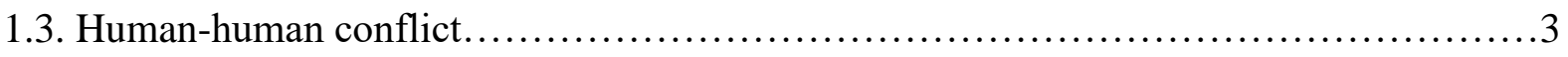

1.4. Human-wildlife interactions in urban environments.................................. 4

1.5. Wildlife population decline and reintroduction as a conservation tool....................6

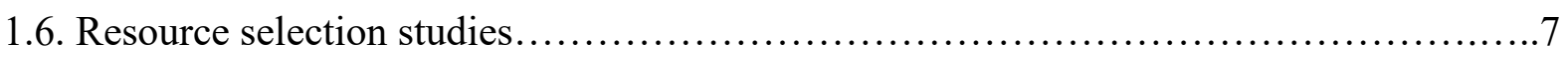

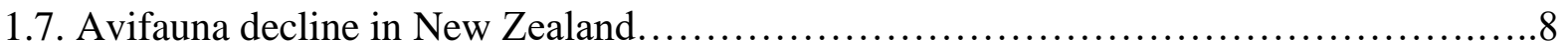

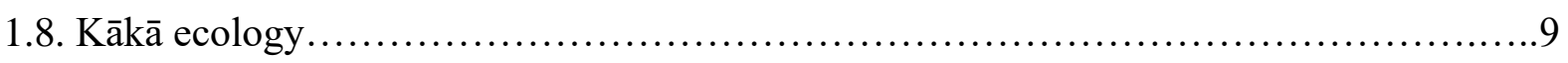

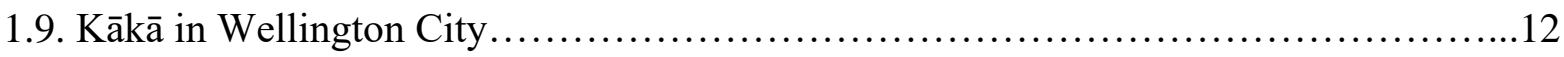

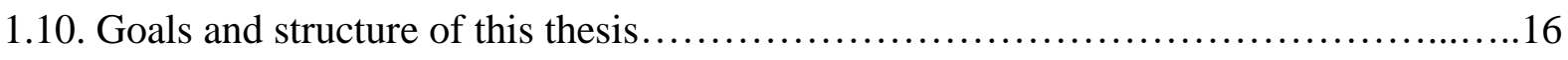

Chapter Two: Kākā resource selection in an urban environment...........................18

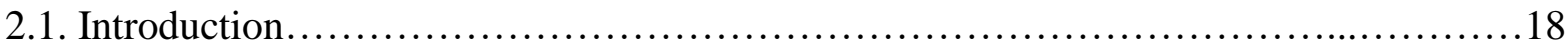

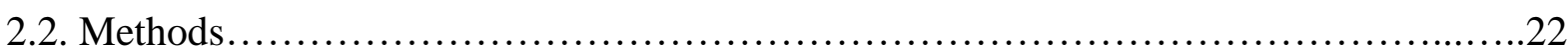

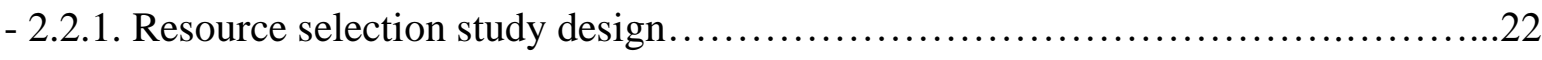

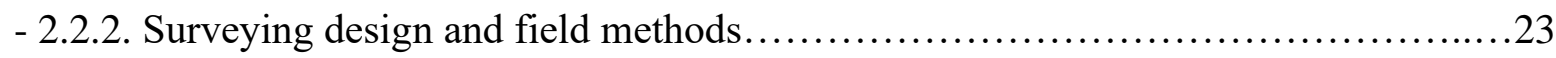

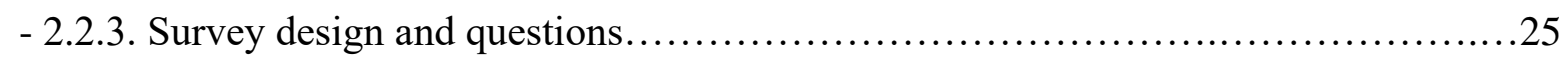

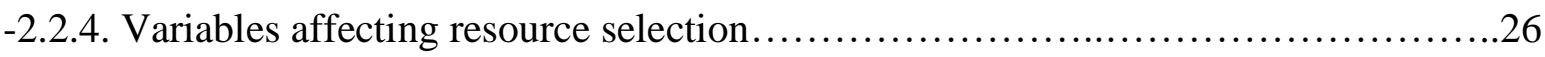

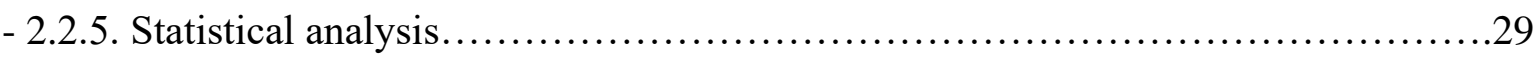

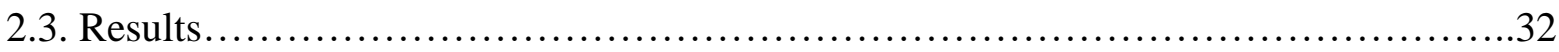

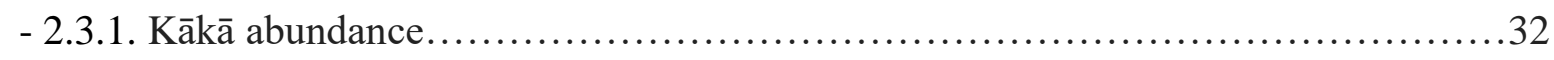

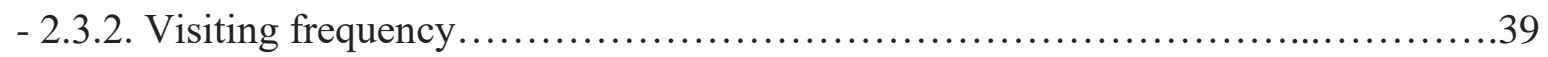

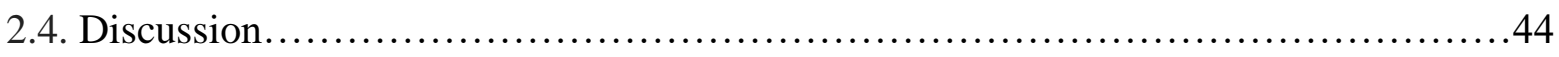

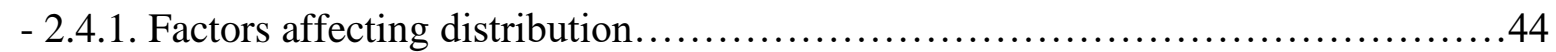


- 2.4.2. Relation to previous studies.............................................. 46

- 2.4.3. Anthropogenic waste as a food source...................................47

2.5. Conclusions and recommendations .......................................... 49

Chapter Three: Wild parrot feeding, damage and the attitudes of Wellington City residents..............................................................................50

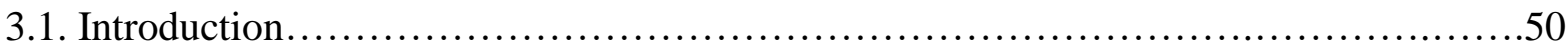

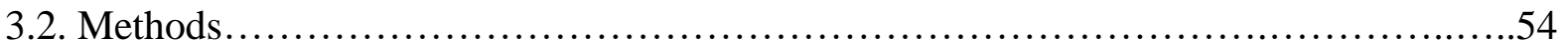

- 3.2.1. Survey design and distribution.........................................54

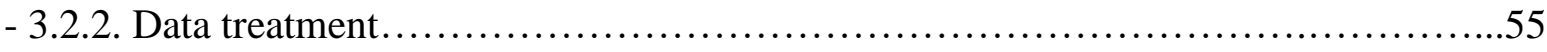

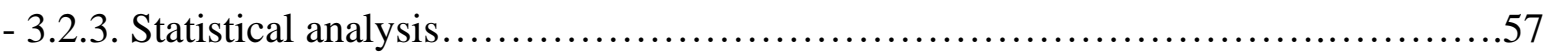

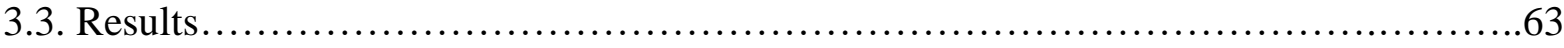

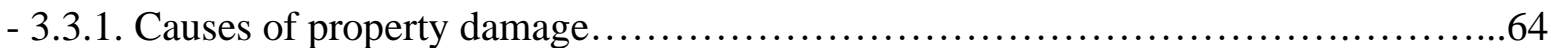

- 3.3.2. Kākā damage and attitudes.............................................. 70

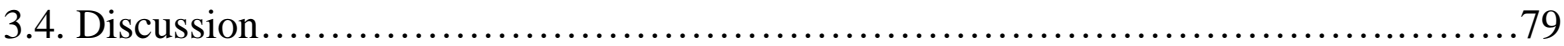

- 3.4.1. Kākā damage.......................................................... 79

- 3.4.2. Attitudes to kākā ........................................................ 82

- 3.4.3. Limitations................................................................ 85

3.5. Conclusion and recommendations .............................................. 87

Chapter Four: General Discussion...................................................88

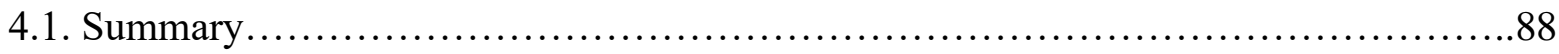

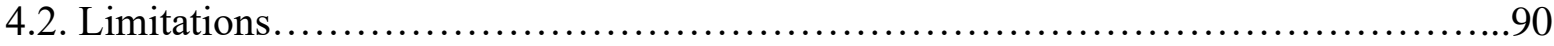

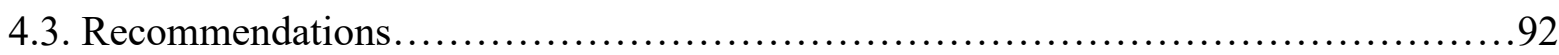

4.4. Further urban reintroductions of kākā........................................94

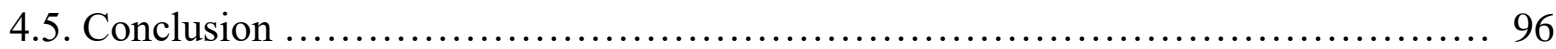

Appendix 1: Introduction letter....................................................98

Appendix 2: Information letter.......................................................99

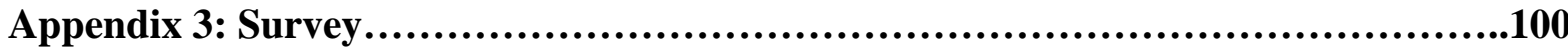

Appendix 4: Linklater et al, (2018) survey........................................104

Appendix 5: Reminder letter........................................................108

References..........................................................................109 


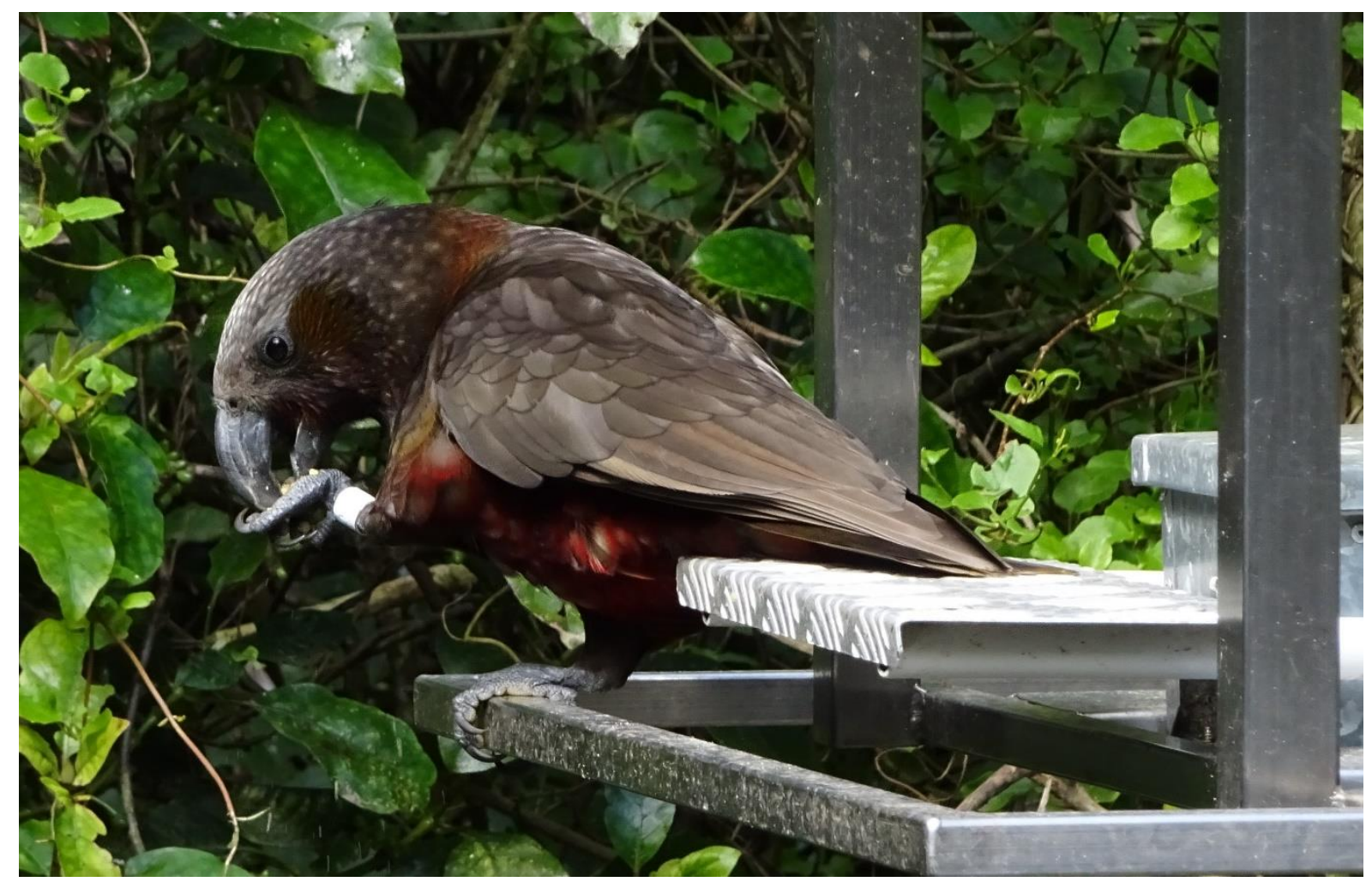

Adult kākā eating a cereal pellet at a supplementary feeder, Karori Wildlife Sanctuary. 


\section{Chapter One: General Introduction}

\subsection{Urbanisation and pressure on the natural environment.}

The earth's human population has increased significantly over the last 50 years, more than doubling from 2.5 billion in 1950 to 6.5 billion in 2005 (Bongaarts, 2009). Reaching 7.4 billion in 2015, it is predicted to climb to 9.7 billion by 2050 (United Nations, 2017). As the population increases, changes in land cover has occurred to accommodate our need for food, shelter and resources. Natural habitats such as forests, grasslands and wetlands have been converted to cultivated land for agriculture and human settlements (Meyer and Turner, 1992). Since the arrival of Maori and European settlers, approximately three-quarters of New Zealand's natural forest cover has been felled, reducing it from $82 \%$ to $23 \%$ (Ewers et al, 2006). This expansion of the human population in both size and range (Cohen, 2003) has led to increased anthropogenic pressure on wildlife and natural ecosystems. The New Zealand archipelago has a growing human population of $1.69 \%$ pa (Stats NZ, 2018), significantly exceeding the world average of $1.10 \%$ pa (World Population Review, 2019). This increasing population is imposing continued habitat loss, as 71,000 hectares of indigenous shrubland, tussock plains and forests were lost between 1996 and 2012 (Ministry for the Environment, 2018). Furthermore, $83 \%$ of New Zealand's indigenous, land-based vertebrate taxa are either threatened, or at risk of extinction (Ministry for the Environment, 2018). This scenario, where human population growth exerts pressure on natural ecosystems inevitably makes conflict involving wildlife and people a growing challenge.

\subsection{Human-wildlife conflict}

The proximity of wildlife and people leads to a competition for space and resources (Madden, 2004) and creates situations in which conflict can arise. Human-wildlife conflict (HWC) occurs when the needs and behaviour of wildlife impact negatively on people, or when the 
behaviour of people impacts negatively on the needs of wildlife (Madden, 2004). This conflict can take many forms such as property damage, livestock predation, attacks on humans themselves and wildlife habitat degradation (Ogra and Badola, 2008).

While HWC is most often thought of as a problem in rural landscapes it also occurs in the urban environment (Messmer, 2000; Wagner et al, 1997). Wagner et al, (1997) evaluated the compensation programs for wildlife damage in North America. Over 60\% of urban and suburban households in the United States experienced conflict with wildlife annually. These urban households also reported a total loss of US\$1.9 billion due to wildlife damage to properties. With urbanisation increasing and more than two thirds of the world's population expected to live in cities by 2050 (Gomez-Baggethun and Barton, 2013), conflict in urban areas is an escalating issue.

It is increasingly unlikely for residents to support wildlife conservation efforts if they have negative experiences with wildlife. An individual's environmental sensitivity can be defined as a predisposition to take an interest in the environment, care for it and act to conserve it, and is largely based on one's experience with nature, including our 'formative experiences' (Chawla, 1999; Dunn et al, 2006). The research of Chawla (1999) and Dunn et $a l,(2006)$ approach this issue from a positive perspective, outlining that direct experience with nature, especially growing up, can lead to greater environmental appreciation and engagement. However, if these formative experiences with nature are negative, such as wildlife continually damaging property that may have high financial or sentimental value, it can be equally suggested that individuals may become less predisposed to support environmental or conservation efforts.

HWC is one of the greatest challenges facing conservation (Dickman, 2010). Human attitudes and views towards wildlife have a large influence on conservation efforts, particularly in policy setting, funding and community engagement. Despite the problems that may arise with wildlife in urban environments, there are unquestionable benefits from the 
presence of wildlife in these environments. Interaction with wildlife creates opportunities for education and community engagement, has physical and mental health benefits, and allows for residents to develop a connection with nature (Miller, 2005; Dunn et al, 2006; Whitburn et al, 2018). Empirical studies by Whitburn et al, (2018) and references therein, show that this closer connection to nature through direct exposure leads to an increase in proenvironmental behaviour (PEB). PEB is defined as conscious actions that seek to reduce one's negative impact on the environment (Kollmuss and Agyeman, 2002). It highly likely then, that these PEBs result in people being more inclined to support environmentally centred policies that in turn can positively affect conservation efforts outside cities. The challenge then for the scientists and wildlife managers is to find solutions which ideally minimise the negative impact of wildlife presence while maintaining the benefits. Addressing and minimising the negative attitudes arising from conflict is vital for coexistence between humans and wildlife in cities.

\subsection{Human-human conflict}

While conflict involving humans and wildlife is most commonly thought of as humanwildlife conflict as described previously, Peterson et al, (2010) suggests that this may often be a misconception. After an extensive literature review, they indicate that many instances that were labelled as human-wildlife conflict would be more accurately described as conflict between people over wildlife, or human-human conflict. This often involves disputes between different stakeholder groups over wildlife management goals or priorities (Marshall et al, 2007). Conflict arises when the priorities of these stakeholder groups differ, and one group asserts, or is perceived to assert their priorities at the expense of others (Marshall et al, 2007; Madden and McQuinn, 2014). This can be seen in the conflict involving orangutans (Pongo pygmaeus) and palm oil (Elaesis guineesis) (Redpath et al, 2015). While the establishment of palm oil plantations threatens the habitat of orangutans, the conflict here lies 
between conservationists who wish to protect orangutans and those establishing palm oil plantations (Marshall et al, 2007). The priorities of these two stakeholders differ significantly, with each trying to assert their goals at the expense of the other. Messmer (2000) and Manfredo and Dayer (2004) propose that the resolution to these human conflicts involving wildlife is a societal issue. Increasing the tolerance of humans towards wildlife will help minimise the impact of wildlife damage. This can be achieved by trying to enhance an individual's appreciation for wildlife and its non-tangible benefits such as stress relief and relaxation through positive experiences with wildlife (Curtin, 2009; Cox and Gaston, 2016, Whitburn et al, 2018). However, this is not always straightforward in an urban environment as there may be many different societal and cultural views towards wildlife condensed together, often in conflict with one another (Sasidharan and Thaba, 2004). The work of Manfredo et al, (2017) suggests that these values do not change, unless under extreme largescale circumstances. Instead, progress can be made through compromises and conciliation between conflicting values. Taking these various views into consideration when deciding on conservation approaches is often required to minimise conflict between people and wildlife. In conjunction, financial compensation by government bodies for damage done by wildlife is commonly used to help lessen the impact on attitudes (Nyhus et al, 2005; Nelson et al, 2016). By financially compensating the affected parties, they no longer need to expend their own financial resources to repair or replace property that was damaged. This is particularly important if these financial resources are required elsewhere.

\subsection{Human-wildlife interactions in urban environments}

Everyday more and more people are living in cities around the world. This urbanisation has led to approximately half of the world's population of 7 billion people living in urban environments with it expected to rise to $60 \%$ by 2030 (Picket et al, 2001; Miller, 2005). 
As urbanisation increases, there is a potential separation of residents in cities from wildlife and experience in wilderness areas (Dunn et al, 2006; Miller, 2005). This separation can be caused by several factors such as a lack of means (either financial or physically restricted by lack of transport) to get out of the city, reduction in available time due to work commitments, and the increased preference for people to spend time indoors with technology such as television and digital devices (Miller, 2005; Ives et al, 2017).

Due to these restrictions, urban wildlife species may be the only interaction that people have with wildlife in large metropolitan landscapes. Our interaction and first-hand experiences with these urban species are thus crucial. It is thoroughly documented that people's willingness to engage in environmental or wildlife related conservation stems from our direct first-hand experience with nature, particularly from a young age (Tanner, 1980; Dunn et al, 2006; Miller, 2005; Cox and Gaston, 2016; Chawla, 1999). Deep-seated, environmental related attitudes are acquired at a young age and often persist into adulthood (Ives et al, 2017). Dunn et al, (2006) proposes the idea of a 'Pidgeon paradox'. This suggests that for people to be interested in conserving wildlife in what is traditionally thought of as 'out there' nature, it is our interaction with seemingly unextraordinary wildlife species, such as pigeons and fragmented greenspaces that are found in cities that will drive engagement.

In western society, residential bird feeding in the urban environment is a very popular way of interacting with wildlife (Galbraith et al, 2014; Cox and Gaston, 2016). There are several reasons as to why people engage with feeding. Cox and Gaston (2016) found feeders had a strong positive response to psychological benefits such as connectedness to nature and relaxation when watching birds in their garden. Of the feeders that were surveyed in Galbraith et al, (2014), 50\% stated their main driver for feeding was a sense of pleasure. Other drivers included assisting birds through periods where food is scarce such as winter, to disposal of old food such as bread and for the benefit of education for children. However, feeding birds in cities also has potential risks. Feeding can influence avian assemblages and 
distribution and introduces the risk of spreading avian diseases (Galbraith et al, 2015, Robb et al, 2008). In some cases, feeding can also bring opportunities for conflict to arise by attracting animals in higher than usual concentrations (Belant, 1997; Solsbury and White, 2016; Linklater et al, 2018).

\subsection{Wildlife population decline and reintroduction as a conservation tool}

Humans have adversely impacted wildlife in several ways such as habitat destruction, introduction of invasive species, pollution, human over-population and overexploitation of wildlife. These have all caused wildlife population decline and in severe cases, have led to extinction (Sax and Gaines, 2008; Mantyka-pringle et al, 2012; Holdaway and Jacomb, 2000; Crist et al, 2017; Jepson et al, 2016).

Reintroduction is a conservation tool that can be used to help mitigate the impacts of wildlife population decline. It is the practice of reintroducing a species that was once made locally extinct or relocated from its natural environment, back into its historical range once the threats that caused their decline have been mitigated (Seddon et al, 2007). One example of this is the reintroduction of grey wolves (Canis lupis) into the Greater Yellowstone National Park (GYNP). Wolves were eradicated from the GYNP by 1926 due to Congressionally mandated hunting (Smith and Bangs, 2009). They were reintroduced into the park in 1995-96 to help conserve the species and restore ecosystem processes that had altered in their absence (Fortin et al, 2005; Ripple and Beschta, 2003). This occurred after the introduction of the Endangered Species Act in 1973 and 20 years of public debate (Fritts et al, 1997; Smith and Bangs, 2009). Thirty individuals were relocated from Canada into the park and the translocation has been considered a success, with the population estimated at 210 by 2002 (Smith et al, 2003). However, this reintroduction has also been a source of conflict as the wolves have been reported to prey on livestock on farms at the edge of the park and occasionally attack humans (Nyhus et al, 2005; Bangs et al, 2005). 
This conflict is an example of why extensive planning is required in the reintroduction process. Over the course of an animal's absence, local ecosystems are often subject to anthropological changes such as forestry clearing, agricultural intensification and urbanisation (Hannon and Hafernik, 2007; Linklater et al, 2018). As urbanisation increases, it is becoming more common for conservationists to reintroduce wildlife back into areas proximal to humans (van Heezik and Seddon, 2018; Linklater et al, 2018). In these people dominated environments, wildlife conservation and management occur in a complex system with social, economic and ecological components (Marshall et al, 2007; Madden and McQuinn, 2014; Linklater et al, 2018). Interaction and conflict between humans and wildlife is inevitable and should be planned for. The International Union for Conservation of Nature (IUCN) has compiled guidelines which outline the logical processes necessary for successful reintroduction or translocation events (IUCN, 2018). These guidelines reinforce the need to address social, economic and political factors when considering feasibility and risk assessment in reintroductions with a human element.

\subsection{Resource selection studies}

Habitat selection is the behavioural process in which animals choose the most suitable locations in their environment to maximise their fitness (Northrup et al, 2013). Resource selection studies track these preferential areas that animals use (Copper and Millspaugh, 1997, Manly et al, 2007). This is of interest if a species is being reintroduced back into its historic range, especially if it the environment may have changed in its absence, or if it is a novel study of a species whose use of its natural habitat is not yet fully known. As urbanisation increases, wildlife may be reintroduced into areas that are now proximal to, or inside urban landscapes (Hannon and Hafernik, 2007; Linklater et al, 2018). Furthermore, wildlife that would normally habituate rural or wilder areas may also establish subpopulations in urban landscapes of their own accord, without human input (Davis et al, 2012; 
Aguiar et al, 2014). Urbanisation has many diverse impacts on the environment, but may include; i) the alteration of habitat, particularly the fragmentation and loss of native habitat, ii) alteration of resource flows and the reduction in net primary production, iii) alteration of disturbance regimes, with habitats often experiencing increased and managed disturbance, and iv) the alteration of species compositions (Gaston et al, 2005 and references within). Understanding how animals use urban environments to maximise their fitness in the face of these ecological impacts is important to optimising conservation efforts, when they are needed. Furthermore, government and regional council bodies will be better informed in how to mitigate any human-wildlife, or human-human conflict, should it arise.

\subsection{Avifauna decline in New Zealand}

New Zealand is a small island nation that, 82 million years ago, separated from the continental body comprising then of Australia, Antarctica and South America. Its biodiversity evolved in comparative isolation until the arrival of Maori ( 700-800ya) and European settlers ( 170ya). This has led to very high levels of endemism across different taxa, particularly aves (71\%) and vascular plants (81\%) (Wallis and Trewick, 2009; Duncan and Blackburn, 2004; Brockie, 2012). With the exception of bats (Chalinolobus tuberculatus and Mystacina spp), New Zealand's biodiversity evolved in the absence of land mammals. As a result, the New Zealand avifauna has life-history and behavioural strategies unsuited to living with mammal competitors and predators. Over the last 700 years since the arrival of Maori settlers and European colonisation, many small mammal species such as stoats, possums, rats and domestic cats and dogs have been introduced to New Zealand (Clout and Lowe, 2000). This was detrimental to New Zealand's native, especially endemic, species as they lacked the necessary predator escape responses needed to deal with the introduced mammals. This led many species to severe population decline and extinction (Clout and Lowe, 2000; Duncan and Blackburn, 2004). In efforts to ensure the survival of these threatened species, the 
relocation and reintroduction to and from predator-free sanctuaries, offshore islands and suitable mainland locations has played a significant role in New Zealand's avian conservation efforts.

\subsection{Kākā ecology}

The North Island Kākā (Nestor meridionalis septentrionalis) is a large, forest dwelling parrot that is endemic to New Zealand. It is classified as Endangered (IUCN, 2019). Individuals weigh between 350-650 grams (Moorhouse, 1994) and have an olive- brown plumage with bright orange feathers on the underside of the wings. A South Island subspecies (N.m.meridionalis) is also recognised, despite having no notable genetic or morphological differences (Powlesland et al, 2009; Holdaway et al, 2001). Despite the restricted range since European arrival, kākā occur in a diverse range of forest types, including podocarp and beech forest (Wilson et al, 1998; Moorhouse, 1994). Nesting behaviour and diet are two aspects of their ecology that have a large influence on their success in the wild.

Kākā are secondary cavity nesters, using existing hollows or openings in tree trunks to build their nests in, while also displaying the ability to adapt to artificial nest boxes. Breeding can be infrequent, and it is proposed to be related to seasons of high production of fruit by podocarps or seeds by beech (O’Donnell and Rasch, 1991; Powlesland et al, 2009). Clutches consist on average of four eggs with females contributing solely to incubation, a period of approximately 20 days (Powlesland et al, 2009). Sole incubation by females means that the clutch is often unguarded when females periodically leave the nest to feed. These aspects of nesting behaviour mean kākā are often highly susceptible to predation by introduced mammals during this period (Powlesland et al, 2009).

Moorhouse et al, (2003) showed that the control of mammalian predators can help increase the breeding success of kākā females in managed sites. Three sites across New Zealand were managed for mammalian predators using poison baited traps. This was 
compared to three control sites in which there was no active management. Between 13 and 54 adult kākā were radio tagged at each site $(\mathrm{n}=178)$. Nesting success was significantly greater in the three managed sites $(86 \%, 87 \%$ and $80 \%)$ than the control sites $(10 \%, 10 \%, 38 \%)$. Moorhouse et al, (2003) proposed that if predator control was the reason for the increased nesting success at the managed sites, then it is reasonable to assume predation is the primary cause of nest failure in the control sites, at least on the biodiversity reserves in which this work was conducted. Egg mortality was deemed to be the largest cause of nest failure, with eggs either preyed on in the nest, removed or abandoned after it was possibly disturbed by predators. Predation on nesting females was the next largest cause of nesting failure. Stoats (Mustela erminea) and brushtail possums (Trichosurus vulpecula) were found to be the main predators responsible for mortalities. Large scale control of stoats in the rural Eglinton Valley, Fiordland (Dilks et al, 2003), was also followed by a similar increase in kākā breeding success similar to that measured by Moorhouse et al, (2003).

While literature proposes that stoats and possums are the main causes for kākā population declines in rural areas and biodiversity reserves, this dynamic may be different in the urban environment. While stoats and possums can be managed through trapping and poison baits in most landscapes, other potential predators, such as domestic cats and dogs, cannot be controlled in the same manner. Domestic cats have a main food source supplied by the owner. Cat populations are density-dependent on the human population and the subsequent urban density, rather than dependent on prey species (Baker et al, 2008) and therefore, are not restricted by the traditional predator-prey population fluctuations. Due to a high urban density and the fact that cats can leave properties (Baker et al, 2005), cats may still substitute for stoats as a threat for nesting kākā females and a cause of egg and fledgling mortality in an urban environment, despite not being a primary food source. Dogs are more restricted in their ability to directly impact kākā as they ordinarily do not leave the property without an owner accompanying them. However, they may still act as a deterrent or predator 
of kākā on private properties, or out in the neighbourhood when taken for various recreational activities. To understand the threat of predators on kākā's survivability in the urban environment, it is reasonable that the effects of domestic predators such as cats and dogs should also be considered.

Kākā across New Zealand have a diverse diet, enabling them to switch primary food source based on seasonal availability and nutritional requirements (O'Donnell and Dilks, 1994). Moorhouse (1997) identified and quantified the foods and foraging activity of North island kākā on Kapiti Island. Nine kākā (three males and six females) were captured and fitted with radio transmitters. Behaviour was recorded between March 1991 and January 1992. The recorded birds foraged predominantly (approx. 40\%) for wood boring invertebrates (WBI) throughout the study period. However certain plant foods from species such as hinau (Elaeocarpus denatus), five-finger (Psuedopanax arboreus) and tawa (Beilschiedia tawa) were found to be important in their diet. All birds recorded fed almost exclusively on hinau seeds in March. While the males continued to feed primarily on hinau seeds until June, all females stopped eating hinau after March. One female with a dependent fledgling, foraged exclusively for pukatea (Laurelia novae-zelandiae) seed in April, while the other females returned to foraging for WBI. Most birds spent approximately $30 \%$ of the observed time feeding on five finger nectar or pollen throughout August. Foraging for tawa seed increased later between November to January. This change in diet across the study period was proposed to reflect increased nutritional demands such as moulting, or a decrease in food abundance or quality. Sap feeding was infrequently observed, although the authors hypothesise that this is restricted to breeding females. This diet diversity was reflected by O'Donnell and Dilks' (1994) study of South Island Kākā in broadleaf rainforests of South Westland. The diet there also comprised of predominantly WBI, supplemented by seeds, nectar and pollen. The wide range of food that kākā can utilise indicates a generalist diet. Their ability to adapt to a wide diet, including anthropogenic food at feeders, increases their 
ability to adapt to urban environments and the likelihood of conflict (Charles and Linklater, 2013).

\subsection{Kākā in Wellington City}

Wellington City, New Zealand's capital city, is situated in the southern North Island (41.2809' S, 174.7316'E). It has a residential population of 190,956 , but also contiguous with the greater Wellington Region's urban area including three other cities; Porirua, Lower Hutt and Upper Hutt, for a total of 471,315 residents (Statistics New Zealand, 2013). Wellington City's population is slightly female-skewed (52\% female: $48 \%$ male). The median age is 33.9 , with $9.5 \%$ of residents being 65 or older.

Wellington City is built around the shore of a harbour inlet. Its suburbs are built on the surrounding steep hill-country. Private gardens and steep topography mean that suburban Wellington City has a large amount of unbuilt, vegetated land and a network of public green spaces, such as parks, and private and community gardens. Suburban buildings are predominantly detached, single-family household dwellings on comparatively large private lots. In the greater Wellington Region $64.9 \%$ of households own the property (Statistics New Zealand, 2013).

North Island Kākā (Nestor meridionalis septentrionalis) were reintroduced to Wellington City in August 2002. Six breeding kākā were introduced into Karori Wildlife Sanctuary (KWS), a reserve fenced to exclude introduced mammalian predators and situated in the town belt of Wellington City (Charles,2012; Charles and Linklater, 2013). The Karori Wildlife Sanctuary, also known commercially as Zealandia, is a 225-hectare ecological restoration project and now more recently a tourism venture. It was fenced in 1999 to exclude introduced mammals and provide a sanctuary for the reintroduction of New Zealand's native wildlife. KWS is home to numerous endangered native wildlife species including tuatara (Sphenodon punctatus), kokako (Callaeas wilsoni), takahe (Porphyrio hochstetteri) and kākā 
(Nestor meridionalis). The foliage is predominantly coastal broadleaf with sections of exotic conifer forest (Blick et al, 2008). One of its goals is to restore the podocarp/broadleaf lowland forest habitat and fauna to what would have been prior to Maori and European settlement. The valley that the sanctuary is situated in used to function as a water source for the city, following the construction of a dam in the northern, lower end of the valley in 1878 . The dam was decommissioned in 1997, but the dam wall, while inactive, was retained. As a result, two reservoirs are found in the sanctuary and act as support for numerous bird species.

KWS is approximately two kilometres from Wellington City's central business district and partly surrounded by residential suburbs on all but its southern boundary. The sanctuary is managed by the non-profit Karori Sanctuary Trust, established in 1995 and supported by philanthropic and local government funds. The trustees are appointed by the local, democratically elected City Council. While it is known commercially as Zealandia, throughout this thesis it will be referred to as Karori Wildlife Sanctuary or KWS.

Following several supplementary releases since their reintroduction and a local breeding program, the kākā population has been estimated to have grown to around 200-250 birds (Charles, 2012).

The reintroduction of kākā to KWS in Wellington City has been important, as kākā populations across New Zealand have declined drastically in both size and range. This decline resulted in kākā being restricted to offshore islands and small fragments of forest on the mainland. The subpopulation in Wellington City is the only urban breeding population of kākā in New Zealand.

The increase in kākā abundance within Wellington City has had mixed reactions from residents. Many residents enjoy the increased presence of kākā and enjoy seeing them on their properties, with some residents even directly feeding kākā. However, there are also occurrences of conflict between some residents and kākā. Due to their feeding behaviour, kākā have been observed to damage trees in their attempts to access sap and wood-boring 
insects (Charles, 2012; Charles and Linklater, 2014). Two techniques are known to be used; i) stripping the bark to expose the surface cambium and ii) creating lateral gouges (O'Donnell and Dilks, 1989; Charles, 2012). Bark and phloem damage can have significant consequences for tree health. Signs of physiological stress such as epicormic growth, has been observed on Eucalyptus spp. exhibiting kākā damage (Charles, 2012). Epicormic growth is characterised by rapid shoot elongation, with little secondary growth, resulting in weaker branch structure. In backyards, weaker tree limbs pose a hazard to residents. This bark damage can also result in crown dieback (Innes, 1994), increase in a tree's susceptibility to pathogens (Beavan, 1996) and in severe cases, tree mortality. Kākā have also been known to damage other parts of property such as roofing, external building cladding and outdoor furniture (Charles, 2013, Charles and Linklater, 2013, Linklater et al, 2018). While this damage occurs on both public and private land, the damage has its biggest impact to residents when it occurs on private property as the cost of repairing it falls to the property owner. 


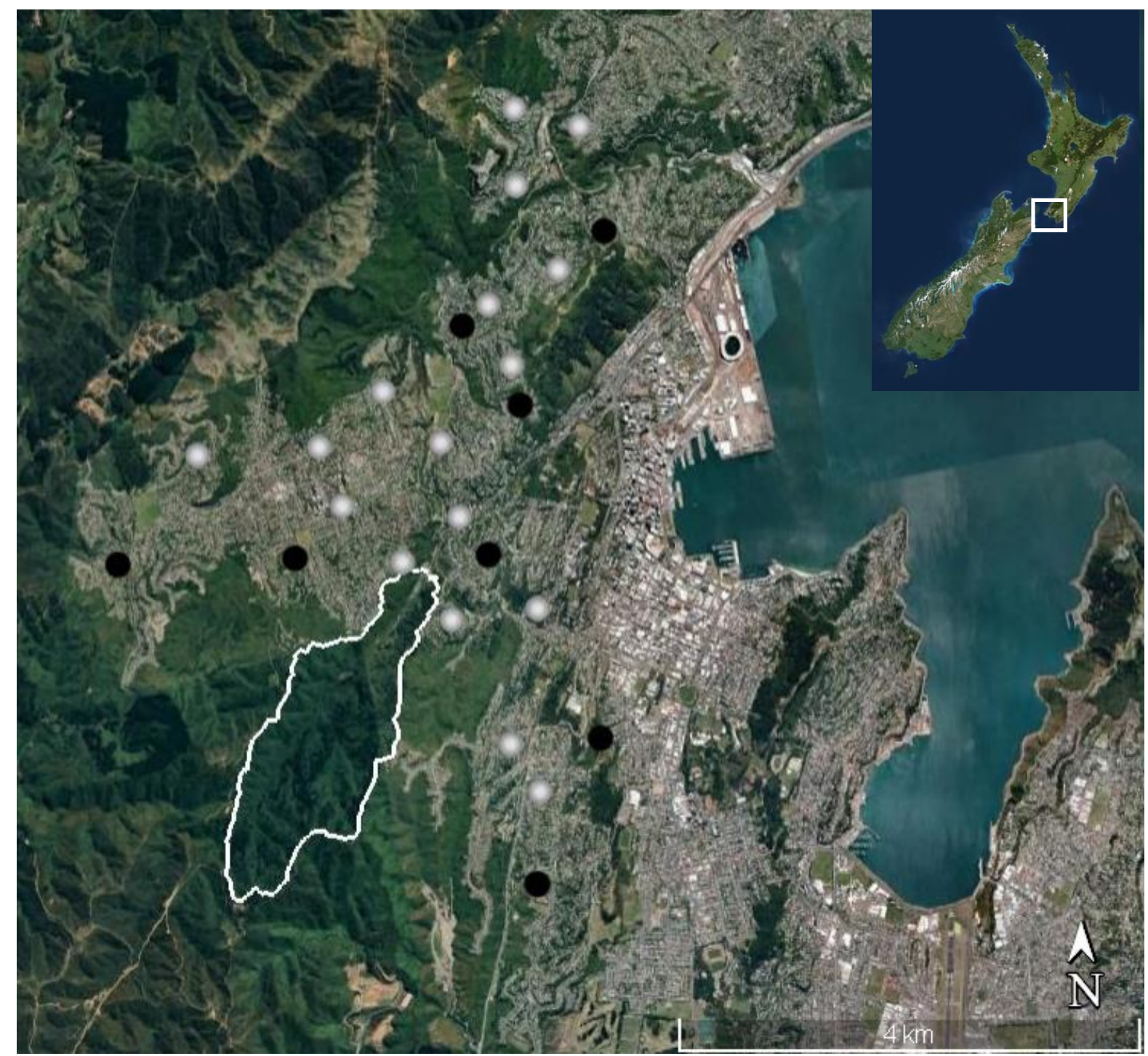

Figure 2.1: Map of Wellington City showing study sites in Wellington City. Sites receiving normal surveys indicated in light grey, sites receiving alternate survey are indicated in black. Karori Wildlife Sanctuary is outlined in white. Location of Wellington outlined in white, top right. Map data: Google Earth, Maxar Technologies (2018). 


\subsection{Goals and structure of this thesis}

This thesis aims to explore the interaction and relationship between people and kākā in Wellington City, and how kākā use the city's urban environment. This will be investigated across two empirical chapters. The first chapter explores kākā's resource selection and distribution across Wellington City's urban environment by examining their presence on residential properties. It investigates which ecological and anthropological drivers, or combination thereof best explain kākā abundance as reported by residents. The second chapter investigates the relationship between residential feeding, damage to residential properties by kākā and the attitudes people have towards kākā and wildlife in general. It asks two main questions; 1) What factors most influence kākā damage on residential properties, and 2) How does this damage affect residents' attitudes towards kākā and birdlife in general?

While there has been prior empirical works on these topics, this thesis aims to collate aspects of these works and further examine the relationship between kākā and Wellington City's urban environment. Despite past studies showing that residents across Wellington have garnered generally positive attitudes towards kākā, negative attitudes caused by damage are also present (Linklater et al, 2018). Discovering what factors cause or exacerbate damage by kākā on properties and how this damage affects residents' attitudes will help find pathways to mitigate the conflict and is a vital step in improving this unique relationship between people and kākā in the urban environment.

Having a deeper understanding of what environmental factors best explain kākā distribution is also important. It can help city planners decide the composition and positions of green spaces to reflect the habitats they prefer. Furthermore, understanding the factors that drive the habitat choice of kākā can help future studies predict their spread as the population grows.

This thesis also provides some recommendations on how to minimise the conflict or mitigate the negative attitudes arising from this conflict. It is hoped that the information 
gained from this thesis will inform parties such as KWS, the Department of Conservation and the Wellington City Council and help make conservation decisions that act in the best interests of both kākā and Wellington City residents. 


\section{Chapter Two: Kākā resource selection in an urban environment}

\subsection{Introduction}

Urbanisation has made the study of how species use anthropogenic environments increasingly important. The study of urban ecology investigates the structure and functioning of populations and communities of species in human-dominated landscapes, and how their interaction changes over temporal and spatial scales (Albert, 2008). Urbanisation has diverse effects on the environment and ecologies, which have been well documented (Gaston et al, 2005; Loram et al, 2007). The most prominent of these are (i) the modification, fragmentation and loss of original habitat, (ii) the alteration of resource flows, such as water, by increasing the amount of impervious surfaces such as roads and paving, and the degradation of water quality, (iii) the alteration of disturbance regimes, with many habitats experiencing more frequent disturbances, and (iv) a change in species composition, with many urban areas seeing the introduction of a number of new species and local extinction of others (Davis, 1987; Henry and Dicks; 1987; Ruszczyk and de Araujo 1992; McIntyre et al, 2001). These effects substantially differentiate urban environments from others in their extent and magnitude.

Studies of urban ecology and environments are made complex because they must not only incorporate and address biological factors, but also social, economic and political influences. For example, urban ecosystems are characterised by the presence of private, residential gardens in addition to public greenspace (defined as land that is not built on but vegetated). While individually they may be small with diverse composition, the large number of private gardens means that they can constitute a significant amount of habitat across urban landscapes and facilitate the passage of plants and animals across them (Loram et al, 2007; 
van Heezik et al, 2012). Greenspace in cities is important, therefore, to sustaining populations of wildlife, providing food, shelter and often breeding sites (Smith et al, 2006). However, studying and managing the contributions of private gardens and public greenspace, and their wildlife, to the overall urban ecosystem is difficult. This is due to the relative inaccessibility of private property and public nature of communal greenspace. Private gardens lie mostly outside the control of regional and city government, while public greenspace is governed by a complex diversity of stakeholders (Gaston et al, 2005; Loram et al, 2007; Cameron et al, 2012). Private and public ownership of these spaces means that city-wide improvements to gardens to support biodiversity is dependent largely on the cumulative actions of the residential community (van Heezik et al, 2012).

Resource selection studies of wildlife in urbanised landscapes aim to explain what naturogenic and anthropogenic factors, or combination thereof, best explains a species' use of the environment. Urbanisation processes such as increased habitat fragmentation, human presence and disturbance present novel challenges to wildlife and can exert strong influences on their distribution and abundance (Bozek et al, 2007). These challenges can modify many aspects of a species behaviour such as temporal and spatial movement, diet and nutrition, reproduction and mortality rates (Ditchkoff et al, 2006; Hebblewhite and Merrill, 2008; Lowry et al, 2012). As a result, wildlife species living in urban landscapes may display different life history traits than their counterparts living in less modified landscapes (Ditchkoff et al, 2006; Lowry et al, 2012). For example, Fleischer et al, (2003) observed subpopulations of Florida scrub-jays (Aphelocoma coerulescens) living in suburban areas to spend less time and energy foraging for food, than their rural counterparts. They suggest that this shift is due to the increase in forage availability from anthropogenic food sources such as residential bird feeders. Understanding how and why animals respond differently to urban environments through resource selection studies helps conservationists, wildlife managers 
and government develop strategies for their management, whether that be for their control because they are over-abundant or conservation because they are rare.

The presence of kākā in Wellington City's urban environment is novel, as it is currently the only population of kākā living in an urban landscape. While there has been a range of empirical data on kākā in conserved habitats (e.g., parks, reserves and ecological restoration projects), it is only recently that studies have begun to explore this relationship between kākā and Wellington City. These studies have investigated several aspects of kākā ecology in the urban environment, such as home range (Recio et al, 2016) or feeding-site preferences and diet (Charles and Linklater, 2014).

Tree sap has been suggested as an important food source for kākā in Wellington City, contrary to observations by Moorhouse (1994) in forests. Sap feeding behaviour is the predominant cause of damage to trees throughout Wellington City. Charles and Linklater (2014) found tree damage from sap feeding to be significantly more likely to occur on exotic conifers than native species and especially if they were larger trees on more topographically exposed sites. This contrasts with a study in South Westland forests where 74\% of sap feeding damage caused by South Island kākā was found on a native species, especially Southern Rata (Metrosideros umbellata). Southern Rata comprised only $2.6 \%$ of the canopy trees in the study area, indicating that kākā showed extreme preference for this species for sap feeding (O'Donnell and Dilks, 1989).

Foraging for wood-boring insects also leads to bark damage by kākā. Puriri moth (Aenetus virescens) larvae, living inside a host trees cambium layer, have been observed to be preyed on by kākā (Yule, 2016). Kākā excavate the bark, damaging the bark layers significantly in order to reach the larva. In this case, the selection of host trees to lay eggs by adult A.virescens dictates what trees are damaged by kākā. This was found to be predominantly endemic trees, with a thinner outer-bark layer. 
Recio et al, (2016) investigated habitat selection by kākā in Wellington City. They tracked nine juveniles fitted with lightweight Global Positioning System (GPS) units in and around Karori Wildlife Sanctuary (KWS), from April to September 2012. The home range for each bird was estimated and higher order selection of habitat for activities such as feeding, and roosting investigated. They found that native forest patches and proximity to urban areas close to KWS were used to establish home ranges by the individuals. They propose that this proximity to urban areas could be due to native forest being embedded within the urban environment. They further propose that this proximity to urban areas could also be due to the anthropological feeders on private properties. It is possible that these feeders replicate the supplementary feeders present inside KWS. The authors state that longterm research is needed to assess the importance and impact of these feeders for restoring the population of kākā to Wellington.

The work presented in this empirical chapter is different from previous studies on kākā in Wellington, as it examines kākā presence on residential properties specifically, while previous resource selection studies have focussed to kākā across public land. This chapter asks the question; what naturogenic or anthropogenic variables best explain kākā abundance on private, residential properties across Wellington City suburbs? I hypothesise that sites with increased native vegetation, specifically pohutukawa (Metrosideros excelsa) will experience higher kākā abundance. This is based on findings by O’Donnell and Dilks (1989) in which kākā were found to carry out sap feeding on southern rata (Metrosideros umbellate), a close relative of pohutukawa, disproportionately compared to its availability in the environment. I also hypothesise that sites closer to KWS will see greater kākā abundance as the sanctuary still serves as a source population with the greatest protection for kākā. 


\subsection{Methods}

\subsubsection{Resource selection study design}

A Type 1 study design, as outlined in Manly et al, (2002), was used to determine the resource selection of kākā within the suburbs of Wellington City. A Type 1 design does not track individual animals throughout an area but, rather, uses randomly selected plots or transects across the space to record their presence and abundance. At each of these transect or plot locations, environmental variables are measured and recorded. Of the three sampling protocols in resource selection studies possible (Manley et al, 2002), this study compares the habitat that is used by the target species (i.e., present), with the habitat that is available for them to use (cf. unused).

Reliable and interpretable resource selection studies such as this require that two particularly critical assumptions be met (Manly et al, 2002). The first is that the locations that are available to the animals or population of animals being studied must be correctly identified. If some locations are not available, due to physical barriers or distance considerations, the assumption is violated. Second, the defined and measured resource units (fixed-effect variables) that characterise locations in the study must be related to the target species and do not change during the study.

These assumptions were addressed as best as possible when designing the study. Type 1 studies are susceptible to errors if the sample plots or transects are incorrectly placed. If the plot contains preferred variables but is not visited by the target species due to being out of its dispersal range, it may provide misdirecting results. However, in this present study, dispersal range from an original point (KWS) was a desired test variable. Therefore, consideration had to be given to the extent to which kākā may have dispersed through the city suburbs outwards from the KWS. Anecdotal evidence on kākā presence and locations in previous empirical 
work was used to set approximate boundaries when selecting plot locations within the study area. Kākā are proficient fliers and so they are much less, if at all, affected by physical dispersal barriers such as roads, fences and buildings that would hinder other species. This ensures that all plots across the study area will be able to be accessed. Thorough background reading of previous empirical research on kākā was carried out prior to the study to correctly define the variables. These included work on kākā ecology in general and more specifically, more recent works on kākā in the urban environment. From this, variables were chosen, and models created that accurately reflect factors that will most likely affect kākā resource selection. Pilot study data and anecdotal evidence regarding kākā behaviour have also been used. The variables chosen were also ones that could not or, were unlikely to change over a temporal or spatial scale during the study. These variables were obtained through physical measurements on-site, measurements from online data and maps and self-reports by residents.

\subsubsection{Surveying design and field methods}

Twenty-five sites within the suburbs of Wellington City $\left(41.2809^{\circ} \mathrm{S}, 174.7316^{\circ} \mathrm{E}\right)$ were chosen as plots at which to measure kākā abundance and environmental variables. Sites were randomly chosen by selecting points on Google Maps (2018). If the site chosen was in a green space, such as a sports field or reserve, the point was moved to the nearest adjacent residential street.

Postal surveys [Appendix 3] were distributed to 600 households across these 25 sites, with 24 adjacent households centred around each site. Households were identified initially on Google Maps before delivery. Where possible, properties were selected evenly on either side of the street.

To improve response rates (Dillman et al, 2009), an introductory letter [Appendix 1] that notified residents about the study and impending arrival of the survey was first delivered 
to each address. These were delivered by hand to confirm the suitability of each residence. Unsuitable households were those that appeared unoccupied, under construction or being renovated, and these were excluded. In these circumstances, another suitable household adjacent to those originally outlined was included instead. If there was more than one household on a property (e.g., apartments, semi-detached dwellings), only one received a survey. These introductory letters were hand delivered over the course of April and May 2018 .

Approximately seven days after the delivery of introductory letters to a site, surveys that were coded by suburb were delivered by postal mail. These were accompanied by an information sheet explaining the study [Appendix 2]. Also included was an addressed, postage-paid envelop so that residents could return the completed survey without cost. Another seven days after the surveys' delivery, a reminder letter [Appendix 5] was also delivered. The purpose of this was to remind the residents if they have forgotten to return the survey, but also to thank those that have already responded.

An identical survey was created online using the Qualtrics Survey software through Victoria University of Wellington. The reminder letter contained a link to the survey so that residents could have the choice to complete the survey electronically.

This study was approved by Victoria University's Human Ethics Committee (approval number 25242).

As each of the 25 sites was visited, three variables were measured; topographical exposure, tree heights and the number of emergent trees. Topographical exposure (TOPEX) was obtained by measuring the inclination to the horizon at each of the eight cardinal and inter-cardinal compass points; N, NE, E, SE, S, SW, W, NW. This was measured from approximately the centre of the site using an inclinometer. All eight scores were added up to give an overall exposure score. Chapman (2000) outlines a range of TOPEX scores and the 
correlated effective exposure. They are: 0-10 as severely exposed, 11-30 as very exposed, 3160 as moderately exposed, $61-100$ as sheltered and over 100 as very sheltered.

To measure tree height, different approaches had to be employed depending on whether the tree base was at the same level as the individual taking the recording or if it was higher or lower. If a tree at its base was at the same elevation as the individual taking the measurements, a manual inclinometer (Brunton, Clinomaster) was used to find the angle between the eye level and the top of the tree. A Trilex rangefinder was then used to measure the distance between the individual and tree trunk at eye level. However, in many cases, trees were either above or below eye height due to Wellington City's topography. In this case, both angles to the top and base were taken. The rangefinder was used to measure the distance to the base of the tree and if possible, the top also. These angles and distances were then used to construct triangles and from there, trigonometric equations were used to calculate tree height. If several trees at a site were of approximately equal height, recordings and calculations were made on up to five trees, with the three tallest being used.

The number of emergent trees at a site was measured by counting the number of trees on each property that stood higher than the house's eave- the point where the roof overhangs the external wall. This was done during a walk-by of the property. The counts were then summed together to obtain a total for each site.

\subsubsection{Survey design and questions}

A household postal survey [Appendix 3] was used to obtain self-report data from residents. The survey was designed on principles outlined in Dillman et al, (2009) to be as simple and least suggestive as possible. It consisted of 14 questions spanning three pages and took up to approximately ten minutes to complete, depending on how much was applicable to the respondent. Of the 14 questions, three questions were relevant for this empirical chapter; 
questions on kākā abundance, questions regarding the ownership of domestic pets such as cats and dogs, and questions regarding the feeding behaviour of the residents.

To gain an index of kākā abundance at each property surveyed, two factors were considered: the frequency with which kākā visited a property and the average group size that visited the property at one time as reported by residents. Residents were asked a question on each in the survey. For both questions, residents were given a series of six categorical answers of increasing frequency and size from which to select. Each answer was given a corresponding ordinal score. Frequency categories were given scores from zero to five.

Instances in which kākā never visited a property were scored as a zero, while kākā that visited more than once a day were given a five. Group size categories were scored one to six, with a single kākā scoring one and a group size of 15 or more scoring a six. The index ranged from zero (no kākā) to 11 (large groups of kākā frequently visiting), the largest possible score. Kākā abundance scores were then compared to several urban and ecological factors to estimate which of these factors, or combination of factors most affect kākā presence on residential properties.

\subsubsection{Variables affecting resource selection}

Wellington City's urban and suburban regions combine both naturogenic and anthropogenic variables which can potentially influence resource selection. These variables were identified from a range of existing primary literature (Simberloff, 1974; Moorhouse et al, 2003; Charles and Linklater, 2014; O'Donnell \& Dilks, 1989; Reico et al, 2016), pilot study results and anecdotal evidence gathered from watching kākā and their behaviour around the city.

Seventeen fixed effect variables were chosen to test against kākā presence (Table 2.1). Variables were measured on-site, from online data and maps, or through the survey. 
Table 2.1: Fixed effect variables chosen to test for effect on kākā abundance, visiting frequency and group size with measurement methods, means $( \pm 1 \mathrm{SE})$, maximum and minimum values.

\begin{tabular}{|c|c|c|c|c|}
\hline Fixed effect variable & Method of measurement & Mean ( \pm 1 SE) & Maximum & Minimum \\
\hline Sum of tree heights $(\mathrm{m})$ & $\begin{array}{l}\text { Measured angle to tree top and base using an inclinometer. Distance } \\
\text { to tree measured using rangefinder. Trigonometric equations used to } \\
\text { calculate height. Three tallest trees summed. Details in Methods 2.2. } \\
\text { Surveying design and field methods. }\end{array}$ & $37.05 \pm 3.17$ & 84.50 & 18.60 \\
\hline Sum of crown size (m) & $\begin{array}{l}\text { Trees that were measured for height were identified and were found } \\
\text { by satellite imaging on Google Earth (2018). }\end{array}$ & $24.74 \pm 1.89$ & 52.50 & 12.30 \\
\hline Emergent trees & $\begin{array}{l}\text { Counted all trees above the eave line of residential properties at a } \\
\text { site. }\end{array}$ & $22.8 \pm 1.73$ & 45 & 11 \\
\hline \multirow[t]{2}{*}{$\begin{array}{l}\text { Number of Pohutukawa } \\
\text { and exotic conifers }\end{array}$} & Counted when visiting sites. & $\begin{array}{l}\text { Pohutukawa } \\
2.72 \pm 0.44\end{array}$ & 8 & 0 \\
\hline & & $\begin{array}{l}\text { Conifers } \\
1.04 \pm 0.42\end{array}$ & 9 & 0 \\
\hline Topographical exposure & $\begin{array}{l}\text { Obtained by measuring the inclination to the horizon at each of the } \\
\text { eight cardinal and inter-cardinal compass points; N, NE, E, SE, S, SW, } \\
\text { W, NW. Further details in Methods 2.2. Surveying design and field } \\
\text { methods. }\end{array}$ & $60.6 \pm 6.92$ & 149 & 3 \\
\hline Elevation (m) & $\begin{array}{l}\text { Elevation was calculated internally by Google Earth (2018) software. } \\
\text { The point of measurement was approximately the middle of each site. }\end{array}$ & $149.56 \pm 8.17$ & 250 & 76 \\
\hline Urban density $\left(\mathrm{m}^{2}\right)$ & $\begin{array}{l}\text { Average property size per site was used to gauge the variable of } \\
\text { urban density. This was calculated by constructing maximum convex } \\
\text { polygons on Google Maps (2018).The area and perimeter of the site } \\
\text { was calculated by identifying points encompassing all the chosen. } \\
\text { properties and measuring them using the ruler function. The area of } \\
\text { the polygon was then divided by the number of properties within. }\end{array}$ & $745.60 \pm 33.08$ & 1082.40 & 359.44 \\
\hline
\end{tabular}




\begin{tabular}{|c|c|c|c|c|}
\hline Fixed effect variable & Method of measurement & Mean & Maximum & Minimum \\
\hline $\begin{array}{l}\text { Size }\left(\mathrm{m}^{2}\right) \text { of and distance } \\
\text { to }(\mathrm{m}) \text { nearest forested } \\
\text { greenspace }\end{array}$ & $\begin{array}{l}\text { These areas were identified using the topographic vegetation } \\
\text { polygons from LINZ and satellite image photography from Google } \\
\text { Earth. Polygons were drawn digitally around these identified green } \\
\text { spaces using Google Earth and the area calculated from that by the } \\
\text { software. The distance between each of the study sites and the } \\
\text { border of the nearest FGS was measured digitally using Google Earth's } \\
\text { measure function. }\end{array}$ & $\begin{array}{l}\text { Distance } \\
204.64 \pm 36.17 \\
\text { Size } \\
9.5 \mathrm{E}+05 \pm 1.7 \mathrm{E}+05\end{array}$ & 785.00 & 55.00 \\
\hline Distance to KWS (m) & $\begin{array}{l}\text { Calculated using ruler tool on Google Earth (2018). Distance was } \\
\text { measured from the middle of the site to the nearest KWS boundary. }\end{array}$ & $1790.8 \pm 230.65$ & 4280.00 & 59.00 \\
\hline Cat and dog density & $\begin{array}{l}\text { Residents asked in the survey- what and how many pets they have on } \\
\text { the property [Appendix 3]. The total for the site was divided by the } \\
\text { number of respondents per site, to get an index of cats and dogs per } \\
\text { residence. }\end{array}$ & $\begin{array}{l}\text { Cat } \\
0.41 \pm 0.05 \\
\text { Dog } \\
0.18 \pm 0.03\end{array}$ & 0.87 & 0.00 \\
\hline Feeders & Residents were asked if they fed kākā in the survey [Appendix 3]. & $0.92 \pm 0.34$ & 7 & 0 \\
\hline $\begin{array}{l}\text { Proximity of native and } \\
\text { exotic vegetation- } \\
100 / 200 \mathrm{~m}\left(\mathrm{~m}^{2}\right)\end{array}$ & $\begin{array}{l}\text { Topographic vegetation maps from Land Information New Zealand } \\
\text { (LINZ) were used to identify major tracts of native and exotic forested } \\
\text { areas (absent of building developments such as housing) around } \\
\text { Wellington City. Vector polygons were used to create layers which } \\
\text { plotted the size and shape of the forested areas. At each site, } 100 \text { and } \\
200 m \text { radius circles were drawn on Google Earth (2018). The area of } \\
\text { any native or exotic forest tracts inside the circles were then } \\
\text { measured and recorded. }\end{array}$ & $\begin{array}{l}\text { Native. } 100 \\
1298.08 \pm 657.72 \\
\text { Native. } 200 \\
11249.20 \pm 3064.94 \\
\text { Exotic. } 100 \\
10.48 \pm 7.25 \\
\text { Exotic. } 200 \\
1409.64 \pm 747.93\end{array}$ & 12,152 & $\begin{array}{l}0 \\
0\end{array}$ \\
\hline
\end{tabular}




\subsubsection{Statistical Analysis}

An information theoretic approach was used to test which variables or combination of variables best explained kākā presence at properties in Wellington City. An a priori model set (Table 2.2), was compiled to build on previous work. Second order Akaike's Information Criterion (AICc) was used to compare log likelihood of each model using linear mixed model regression. As the scale of these variables varied considerably, all the variables were standardised and centred using methods from Gelman and Hill (2012). The formula ( $x$ $\bar{x}) / 2 \sigma$ was used, where $x$ is each entry of the variable from each site and $\bar{x}$ is the variable mean. This analysis was carried out using $\mathrm{R}$ 3.5.1 software and the multi model inference package, MuMIn (Barton, 2018) . 
Table 2.2: A priori hypotheses and models of AIC model tests for overall abundance, visiting frequency and visiting group size.

\begin{tabular}{|c|c|}
\hline Hypotheses & Models \\
\hline $\begin{array}{l}\text { Point of } \\
\text { reintroduction }\end{array}$ & distKWS \\
\hline $\begin{array}{l}\text { Theory of Island } \\
\text { Biogeography- } \\
\text { (Simberloff, 1974) }\end{array}$ & $\begin{array}{l}\text { distfgs } \\
\text { distfgs + sizefgs } \\
\text { distfgs + sizefgs + distKWS } \\
\text { distfgs + sizefgs + distKWS + (distfgs *sizefgs) }\end{array}$ \\
\hline $\begin{array}{l}\text { Predator } \\
\text { avoidance- } \\
\text { (Moorhouse et al } \\
\text { (2003), Pilot } \\
\text { study) }\end{array}$ & $\begin{array}{l}\text { Cat density } \\
\text { Dog density } \\
\text { Cat density + dog density } \\
\text { (Cat density + dog density) * urban density } \\
\text { (Cat density + dog density) * urban density + distKSW } \\
\text { Cat density + dog density + urban density } \\
\text { Cat density + dog density + urban density + distKWS }\end{array}$ \\
\hline $\begin{array}{l}\text { Kākā prefer more } \\
\text { exposed sites with } \\
\text { larger trees- } \\
\text { (Charles and } \\
\text { Linklater (2014), } \\
\text { O'Donnell \& Dilks } \\
\text { (1989), anecdotal } \\
\text { observations.) }\end{array}$ & $\begin{array}{l}\text { Tree height } \\
\text { Tree height }+ \text { crown } \\
\text { Tree height } * \text { crown } \\
(\text { Tree height } * \text { crown) + emergent } \\
(\text { Tree height } * \text { crown) + elevation } \\
(\text { Tree height } * \text { crown) + elevation + TOPEX } \\
(\text { Tree height } * \text { crown })+(\text { elevation * TOPEX) } \\
(\text { Tree height } * \text { crown) + elevation + TOPEX + distKWS } \\
(\text { Tree height } * \text { crown) + elevation + TOPEX + distKWS + emergent } \\
\text { Tree height + crown + emergent } \\
\text { Tree height + crown + elevation } \\
\text { Tree height + crown + elevation + TOPEX } \\
\text { Tree height + crown + (elevation * TOPEX) } \\
\text { Tree height + crown + elevation + TOPEX + distKWS } \\
\text { Tree height + crown + elevation + TOPEX + distKWS + emergent }\end{array}$ \\
\hline $\begin{array}{l}\text { Kākā prefer native } \\
\text { bush, particularly } \\
\text { close to KWS }\end{array}$ & $\begin{array}{l}\text { Native. } 100 \\
\text { Native. } 100+\text { distKWS } \\
\text { Native. } 200 \\
\text { Native. } 200 \text { + distKWS } \\
\text { Pohutukawa } \\
\text { Pohutukawa + native. } 100 \\
\text { Pohutukawa + native. } 100+\text { distKWS } \\
\text { Pohutukawa + native. } 100+\text { distKWS + } \\
\text { (pohutukawa*native. } 100 \text { ) }\end{array}$ \\
\hline $\begin{array}{l}\text { Kākā prefer sites } \\
\text { close to exotic } \\
\text { bush }\end{array}$ & $\begin{array}{l}\text { Exotic. } 100 \\
\text { Exotic. } 100+\text { distKWS } \\
\text { Exotic. } 200 \\
\text { Exotic. } 200+\text { distKWS } \\
\text { Exotic conifers + exotic. } 200 \\
\text { Exotic conifers + exotic. } 200+\text { distKWS }\end{array}$ \\
\hline
\end{tabular}

Table continued

on following page 


\begin{tabular}{ll}
\hline Hypotheses & Models \\
\hline $\begin{array}{ll}\text { Increased use or } \\
\text { preference for }\end{array}$ & Feeders \\
residential & Feeders + distKWS \\
feeders & Feeders + distKWS + urban density \\
& Feeders + distKWS + urban density + (Feeders*distKWS) \\
\hline Kākā prefer less & Urban density \\
dense built areas & \\
\hline
\end{tabular}

Key:

distKWS: distance to nearest KWS boundary

distfgs: distance to nearest forested greenspace

sizefgs: size of nearest forested greenspace

TOPEX: topographical exposure score

crown: tree crown size

emergent: number of trees above eave line

Native.100: area of native vegetation within $100 \mathrm{~m}$

Native.200: area of native vegetation within $200 \mathrm{~m}$

Exotic. 100: area of exotic vegetation within $100 \mathrm{~m}$

Exotic.200: area of exotic vegetation within $200 \mathrm{~m}$

Feeders: number of feeders per site 


\subsection{Results}

Of the 600 surveys delivered, 309 were returned (52\%). Of these returned surveys, eight were not used as they were incomplete. This left 301 surveys to be used as a sample population for this empirical chapter.

Females were $174(57.8 \%)$ of respondents (male: 124 or $41.2 \%)$. There was a significant difference between the sex composition of respondents and that of Wellington City. A significantly higher proportion of females responded to the surveys than those present in Wellington City (Stats NZ, 2013) $(Z=2.16, P=0.015)$. Two surveys were answered by a male-female couple and one respondent identified their gender as 'Other'. Most surveys (158 or $52 \%$ ) were answered and returned by middle-aged (41 to 65 years old) residents: $<25$ years old $(16,5 \%), 26-40(55,19 \%), 65+(72,24 \%)$. A significantly higher proportion of residents between ages 41-65 were sampled by the survey than are present in Wellington City as of the 2013 census $(Z=3.869, P=0.0001)$. Also, a significantly higher proportion of residents over 65 years old were sampled by the survey than are present in Wellington City as of the 2013 census $(Z=5.845, P=<0.0001)$.

Kākā were present on 226 properties (75.1\%). Mean ( \pm 1 SE) kākā abundance score was $3.47 \pm 0.15$ (maximum score of 11 , minimum score of 0 ) across all respondents. The mean visiting frequency score was 2.04 (“once a month") \pm 0.1 (range 0 to 5) and mean visiting group size of 1.43 (" 1 to $2-3$ birds at a time") \pm 0.07 (range 0 to 6 ).

\subsubsection{Kākā abundance}

Of the 48 models in the candidate set to explain the abundance of kākā among properties and neighbourhoods, a large number (20) feature in the confidence model set $(\Sigma \omega=0.95)$. The leading model had only one fixed effect (Feeders per site) and carried a small to moderate Akaike's weight ( $\omega=0.244$; Table 2.3, Figure 2.1). This 'Feeders' fixed effect appears to be 
the strongest influence on kākā site selection out of all predictors tested. All four models that included the Feeders predictor received substantial support $(\triangle \mathrm{AICc}<2)$. Furthermore, the worst model that included Feeders carried substantially more support (i.e., delta AICc >2) and weight than the next best model, which contained predictors for tree size and geographical exposure (Table 2.3).

The distance of a site from KWS (distKWS) was present in three of the four models that received substantial support. This included a model with an interaction between distKWS and Feeders, which was only marginally weaker than the leading model (Table 2.3, Figure 2.2). However, distKWS was also in several poorer performing models and when by itself, also performed poorly $(\triangle \mathrm{AICc}=11.82, \omega=0.001)$. The sum of weights containing the feeder predictor outweighed the sum of weights in models containing the distKWS predictor $(\Sigma \omega=$ 0.742 and 0.578 respectively), although the distKWS predictor was in many more models than the Feeder predictor (19 and 4, respectively). The interaction between distKWS and feeders appears to be driven by only two of the 25 sites (Figure 2.2).

Urban density (a measurement of average lot size) was present in two of the top four models but when by itself was nearly considered implausible $(\triangle \mathrm{AICc}=9.23, \omega=0.002)$. $)$. There was a weak, albeit non-significant, negative relationship between kākā abundance and urban density (Figure 2.3).

Models describing kākā abundance using predictors of proximity to tracts of exotic bush and exotic conifers and presence of domestic predators were implausible $(\triangle \mathrm{AICc}>10$, Table 2.3). The random-effect predictor 'SiteID' was also a poor predictor $(\triangle \mathrm{AICc}=10.99$, $\omega=0.001)$. Therefore, the reporting of kākā abundance does not seem to vary in a systematic way between the surveyed sites and neighbourhoods. 
Table 2.3: The candidate set of 48 linear mixed-effect models as hypotheses for the drivers of resource selection at urban residences by total kākā abundance, reported by Wellington City residents on their properties. Models are ranked by second order Akaike's Information Criterion score ( $\triangle \mathrm{AICc})$ and Akaike weights $(\omega)$. The number of parameters in each model are also shown $(K)$. The number of respondents in the sample $(n)$ is 301 . Models with $\triangle$ AICc scores $<2$ have substantial support. Scores of $<10$ indicate plausible models and $>10$ are implausible models (Burnham and Anderson, 2004).

\begin{tabular}{|c|c|c|c|c|}
\hline Models & 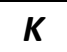 & AICc & $\triangle \mathrm{AICC}$ & $\omega$ \\
\hline Feeders + SiteID & 4 & 1349.80 & 0.00 & 0.244 \\
\hline Feeders + distKWS + urban density + (feeders $*$ distKWS) + SiteID & 7 & 1350.27 & 0.47 & 0.193 \\
\hline Feeders + distKWS + SitelD & 5 & 1350.49 & 0.68 & 0.173 \\
\hline Feeders + distKWS + urban density + SiteID & 6 & 1351.03 & 1.22 & 0.132 \\
\hline$($ Tree height $*$ crown $)+($ elevation $*$ TOPEX $)+$ SitelD & 9 & 1353.50 & 3.69 & 0.038 \\
\hline Pohutukawa + native.100 + SitelD & 5 & 1354.59 & 4.79 & 0.022 \\
\hline (Tree height $*$ crown size) + emergent + SitelD & 7 & 1354.66 & 4.86 & 0.021 \\
\hline Pohutukawa + native.100 + distKWS + (pohutukawa * native.100) + SiteID & 7 & 1355.06 & 5.25 & 0.018 \\
\hline Tree height + crown + emergent + SitelD & 6 & 1355.21 & 5.41 & 0.016 \\
\hline Pohutukawa + native .100 + distKWS + SiteID & 6 & 1355.79 & 5.99 & 0.012 \\
\hline Native. $200+$ SitelD & 4 & 1355.83 & 6.03 & 0.012 \\
\hline Distfgs + sizefgs + SitelD & 5 & 1355.83 & 6.03 & 0.012 \\
\hline Native.100 + SitelD & 4 & 1356.14 & 6.34 & 0.010 \\
\hline (Tree height $*$ crown) + SitelD & 6 & 1356.73 & 6.93 & 0.008 \\
\hline Native.200 + distKWS + SitelD & 5 & 1356.80 & 7.00 & 0.007 \\
\hline$($ Tree height $*$ crown $)+$ elevation + TOPEX + distKWS + emergent + SiteID & 10 & 1356.87 & 7.06 & 0.007 \\
\hline Tree height + crown $+($ elevation $*$ TOPEX $)+$ SitelD & 8 & 1356.91 & 7.11 & 0.007 \\
\hline Distfgs + sizefgs + distKWS + SitelD & 6 & 1357.08 & 7.27 & 0.006 \\
\hline Distfgs + sizefgs + distKWS + (distfgs * sizefgs $)+$ SitelD & 7 & 1357.08 & 7.27 & 0.006 \\
\hline Tree height + crown + elevation + TOPEX + distKWS + emergent + SitelD & 9 & 1357.14 & 7.34 & 0.006 \\
\hline Native.100 + distKWS + SitelD & 5 & 1357.37 & 7.56 & 0.006 \\
\hline (Tree height * crown) + elevation + SitelD & 7 & 1357.74 & 7.94 & 0.005 \\
\hline (Tree height $*$ crown) + elevation + TOPEX + SitelD & 8 & 1358.17 & 8.37 & 0.004 \\
\hline Cat density + dog density + urban density + distKWS + SiteID & 7 & 1358.49 & 8.68 & 0.003 \\
\hline Tree height + crown + SitelD & 5 & 1358.79 & 8.99 & 0.003 \\
\hline Cat density + SitelD & 4 & 1358.92 & 9.11 & 0.003 \\
\hline (Tree height $*$ crown) + elevation + TOPEX + distKWS + SiteID & 9 & 1358.93 & 9.13 & 0.003 \\
\hline Urban density + SitelD & 4 & 1359.03 & 9.23 & 0.002 \\
\hline Pohutukawa + SitelD & 4 & 1359.27 & 9.46 & 0.002 \\
\hline (Cat density + dog density) $*$ urban density + distKSW + SiteID & 9 & 1359.32 & 9.52 & 0.002 \\
\hline Distfgs + SitelD & 4 & 1359.52 & 9.72 & 0.002 \\
\hline Cat density + dog density + urban density + SiteID & 6 & 1359.55 & 9.74 & 0.002 \\
\hline Tree height + crown + elevation + SitelD & 6 & 1359.71 & 9.90 & 0.002 \\
\hline Tree height + crown + elevation + TOPEX + SiteID & 7 & 1359.91 & 10.10 & 0.002 \\
\hline (Cat density + dog density) $*$ urban density + SitelD & 8 & 1360.44 & 10.63 & 0.001 \\
\hline SitelD & 3 & 1360.79 & 10.99 & 0.001 \\
\hline Tree height + crown + elevation + TOPEX + distKWS + SiteID & 8 & 1360.88 & 11.07 & 0.001 \\
\hline Cat density + dog density + SitelD & 5 & 1361.13 & 11.33 & 0.001 \\
\hline Tree height + SiteID & 4 & 1361.46 & 11.66 & 0.001 \\
\hline DistKWS + SiteID & 4 & 1361.63 & 11.82 & 0.001 \\
\hline Exotic conifers + SitelD & 4 & 1361.89 & 12.09 & 0.001 \\
\hline
\end{tabular}

Table continued on following page 


\begin{tabular}{lcccc}
\hline Models & $\boldsymbol{K}$ & AICc & $\boldsymbol{\Delta A I C c}$ & $\boldsymbol{\omega}$ \\
\hline Exotic.100 + SitelD & 4 & 1361.98 & 12.17 & 0.001 \\
Exotic.200 + SitelD & 4 & 1361.98 & 12.18 & 0.001 \\
Exotic.100 + distKWS + SitelD & 5 & 1362.76 & 12.95 & 0.000 \\
Exotic.200 + distKWS + SiteID & 5 & 1362.79 & 12.98 & 0.000 \\
Dog density + SitelD & 4 & 1362.83 & 13.02 & 0.000 \\
Exotic conifers + exotic.200 + SitelD & 5 & 1362.95 & 13.14 & 0.000 \\
Exotic conifers + exotic.200 + distKWS + SitelD & 6 & 1363.70 & 13.90 & 0.000 \\
\hline
\end{tabular}

\section{Key:}

distKWS: distance to nearest KWS boundary distfgs: distance to nearest forested greenspace sizefgs: size of nearest forested greenspace TOPEX: topographical exposure score crown: tree crown size emergent: number of trees above eave line Native.100: area of native vegetation within $100 \mathrm{~m}$ Native.200: area of native vegetation within $200 \mathrm{~m}$ Exotic. 100: area of exotic vegetation within $100 \mathrm{~m}$ Exotic.200: area of exotic vegetation within $200 \mathrm{~m}$ Feeders: number of feeders per site 


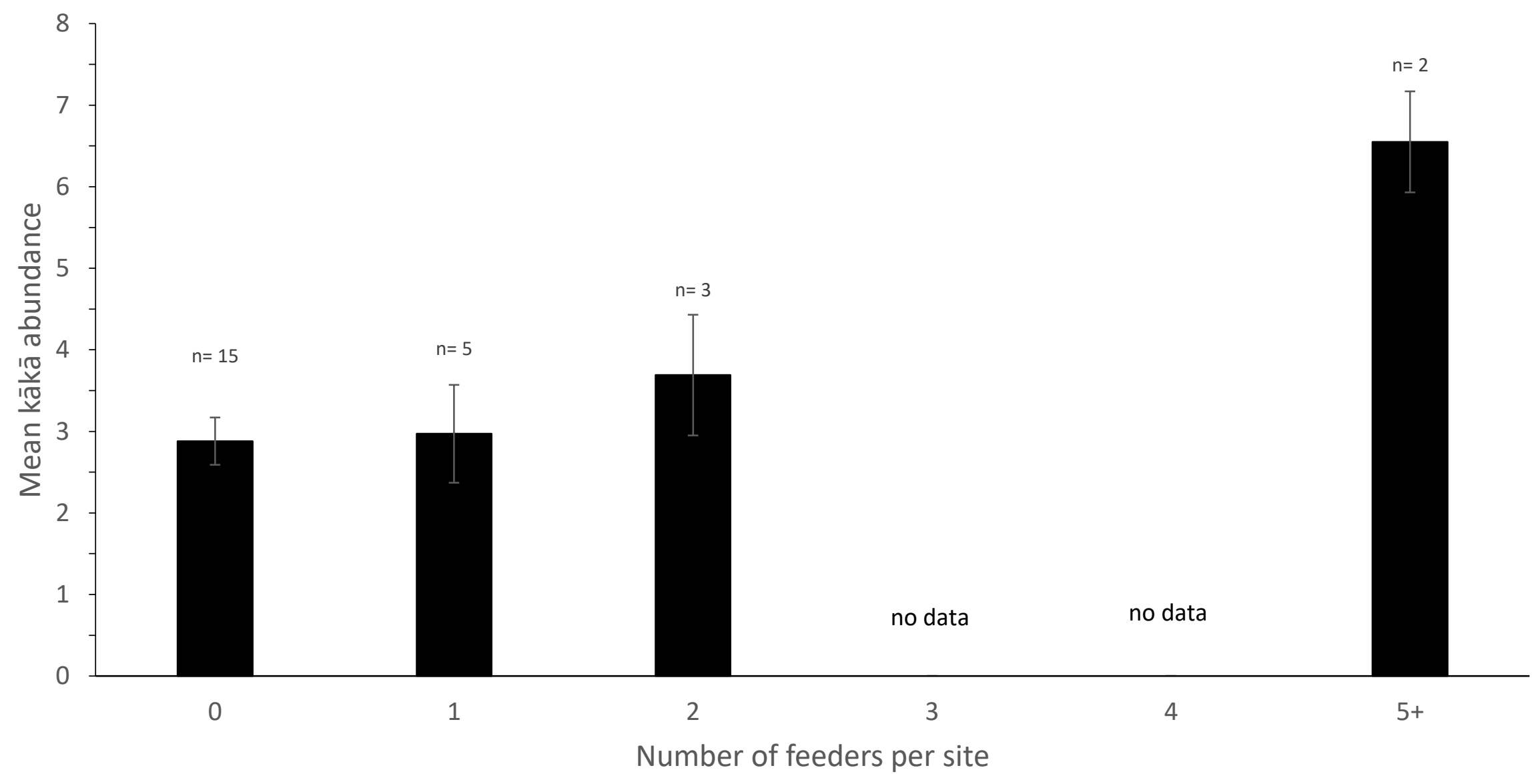

Figure 2.1: Mean kākā abundance ( $\pm 1 \mathrm{SE}$ ) at sites with increasing numbers of residents who feed kākā on their properties. Feeders per site predictor was present in the top four models, for a summed weight of 0.718 . Kākā abundance increased as the number of feeders per site increased. 


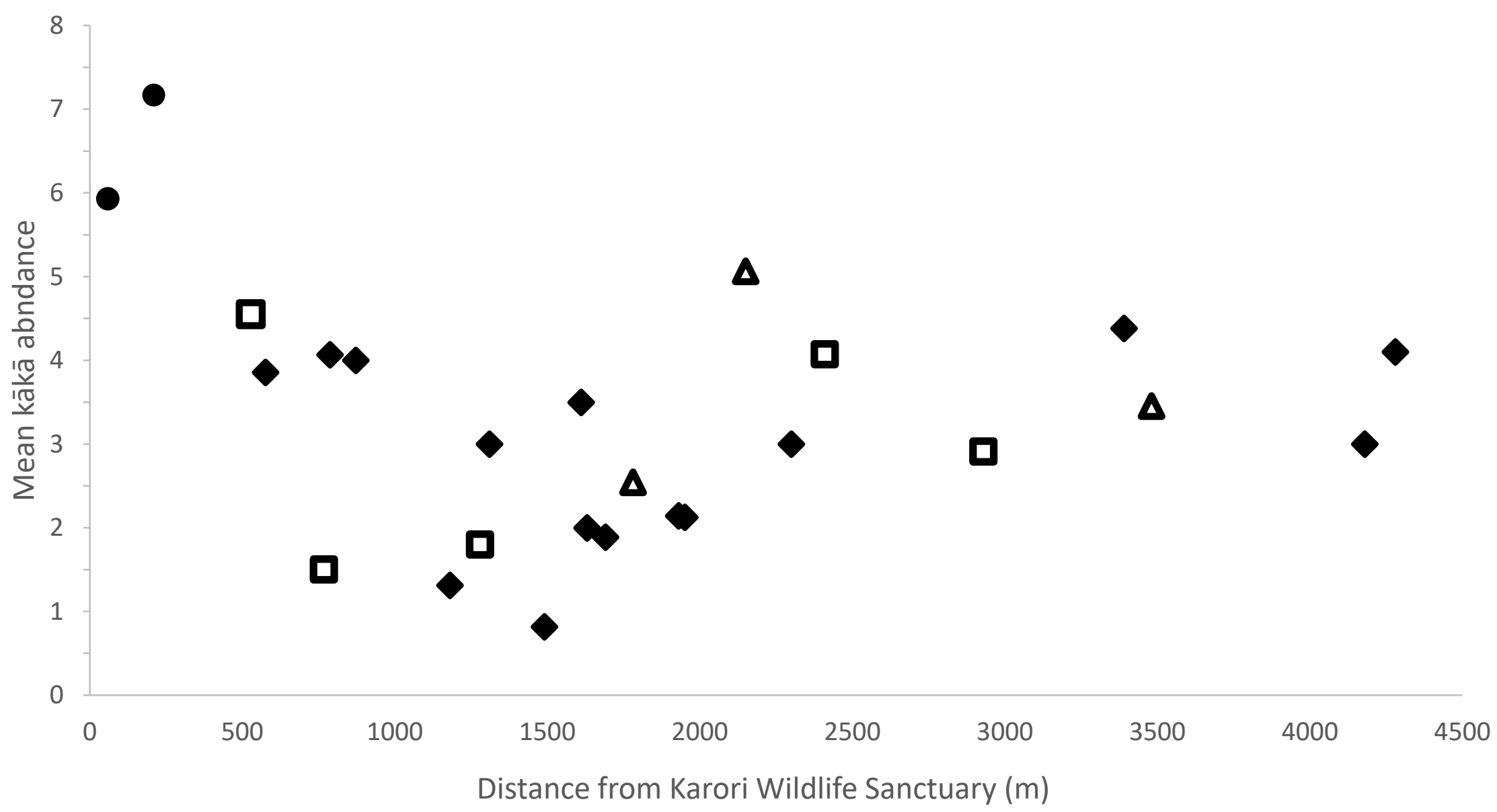

Figure 2.2: Mean kākā abundance at the 25 sites in response to the distance from KWS and the number of residential feeders per site. Markers indicate feeder number; diamonds $=$ no feeders, squares $=1$ feeder, triangles $=2$ feeders and circles $=5+$ feeders. The two sites reporting the most kākā abundance both had 5 or more feeders, reflecting the weight of the feeder predictor. Incidentally, these two sites (indicated by circle markers) were also the closest two sites to KWS. However, outside of these two there appears to be no discernible pattern for abundance and distance to KWS. 


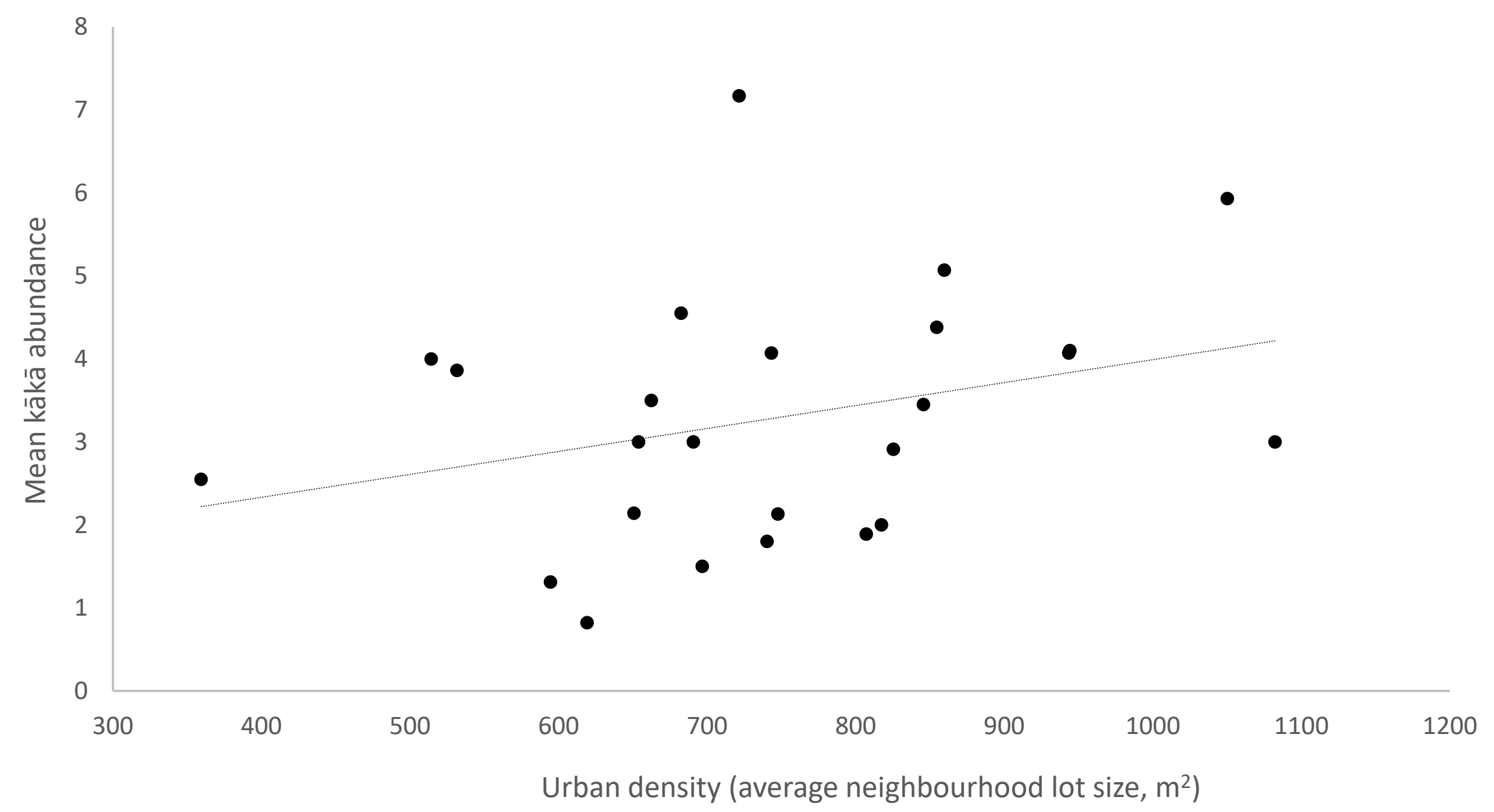

Figure 2.3: Mean kākā abundance across the 25 study sites in response to urban density. Urban density is portrayed in this context as a measurement of mean lot size of a site. $\left(F_{1,23}=2.381, P=0.136 ; R^{2}=0.094\right)$. 


\subsubsection{Visiting frequency}

Of the 48 models in the candidate set to explain the abundance of kākā among properties and neighbourhoods, 20 feature in the confidence model set $(\Sigma \omega=0.95)$. The leading model had only one fixed effect (Feeders) and carried a moderate Akaike's weight ( $\omega=0.437$; Table 2.4). This 'Feeders' fixed effect appears to be the strongest influence on kākā site selection out of all predictors tested. Only the model that received substantial support ( $\triangle \mathrm{AICc}<2)$, containing the feeder predictor by itself, with the random effect variable. Furthermore, the worst model that included Feeders carried approximately twice the weight than the next best model, which contained predictors for site proximity to natural vegetation (Table 2.4).

The distance of a site from KWS (distKWS) was present in the next three strongest models, all which also included the feeder variable. However, distKWS was also in several poorer performing models and when by itself, also performed poorly $(\triangle \mathrm{AICc}=10.16, \omega=$ 0.003). The sum of weights containing the feeder predictor again outweighed the sum of weights in models containing the distKWS predictor $(\Sigma \omega=0.726$ and 0.371 respectively), although the distKWS predictor was in many more models than the Feeder predictor (19 and 4 , respectively).

Models describing visiting frequency using predictors of proximity to tracts of exotic bush, exotic conifers, domestic predator density, urban density, tree size, elevation and topographical exposure were implausible $(\Delta \mathrm{AICc}>10$, Table 2.4$)$. The random-effect predictor 'SiteID' while technically plausible, was also a poor predictor $(\triangle \mathrm{AICc}=8.76, \omega=$ 0.005). Therefore, the reporting of kākā abundance does not seem to significantly vary in a systematic way between the surveyed sites and neighbourhoods.

Models explaining for visiting group size showed strong similarities to those explaining visiting frequency, with only minor differences in AIC weights (Table 2.5). 
Table 2.4: The candidate set of 48 linear mixed-effect models as hypotheses for the drivers of resource selection by kākā visiting frequency, reported by Wellington City residents on their properties. Models are displayed in descending order of likelihood, ranked by second order Akaike's Information Criterion score $(\triangle \mathrm{AICc})$ and Akaike weights $(\omega)$. The number of parameters in each model are also shown $(K)$. The number of respondents in the sample $(n)$ is 301 . Models with $\triangle$ AICc scores $<2$ have substantial support. Scores of $<10$ indicate plausible models and $>10$ are implausible models.

\begin{tabular}{|c|c|c|c|c|}
\hline Models & $\kappa$ & AlCc & $\triangle \mathrm{AICC}$ & $\omega$ \\
\hline Feeders + SitelD & 4 & 1095.16 & 0.00 & 0.437 \\
\hline Feeders + distKWS + SitelD & 5 & 1097.31 & 2.15 & 0.149 \\
\hline Feeders + distKWS + urban density + SiteID & 6 & 1098.73 & 3.58 & 0.073 \\
\hline Feeders + distKWS + urban density + (feeders * distKWS) + SiteID & 7 & 1098.92 & 3.76 & 0.067 \\
\hline Pohutukawa + native. 100 + SitelD & 5 & 1100.21 & 5.05 & 0.035 \\
\hline Native.100 + SitelD & 4 & 1100.61 & 5.45 & 0.029 \\
\hline Native. $200+$ SitelD & 4 & 1101.23 & 6.08 & 0.021 \\
\hline Distfgs + sizefgs + distKWS + (distfgs * sizefgs) + SitelD & 7 & 1101.50 & 6.35 & 0.018 \\
\hline Tree height + crown + emergent + SitelD & 6 & 1101.60 & 6.44 & 0.017 \\
\hline Distfgs + sizefgs + SitelD & 5 & 1101.73 & 6.57 & 0.016 \\
\hline Pohutukawa + native. 100 + distKWS + SiteID & 6 & 1101.97 & 6.81 & 0.014 \\
\hline Pohutukawa + native.100 + distKWS + (pohutukawa * native.100) + SiteID & 7 & 1102.17 & 7.01 & 0.013 \\
\hline (Tree height $*$ crown) + emergent + SitelD & 7 & 1102.37 & 7.22 & 0.012 \\
\hline Native.200 + distKWS + SitelD & 5 & 1102.65 & 7.50 & 0.010 \\
\hline Native.100 + distKWS + SitelD & 5 & 1102.73 & 7.57 & 0.010 \\
\hline Pohutukawa + SitelD & 4 & 1103.49 & 8.33 & 0.007 \\
\hline$($ Tree height $*$ crown $)+($ elevation $*$ TOPEX $)+$ SitelD & 9 & 1103.59 & 8.44 & 0.006 \\
\hline Distfgs + sizefgs + distKWS + SitelD & 6 & 1103.65 & 8.49 & 0.006 \\
\hline SitelD & 3 & 1103.92 & 8.76 & 0.005 \\
\hline Urban density + SiteID & 4 & 1103.95 & 8.79 & 0.005 \\
\hline (Tree height * crown) + SitelD & 6 & 1103.97 & 8.82 & 0.005 \\
\hline Distfgs + SiteID & 4 & 1104.07 & 8.91 & 0.005 \\
\hline Tree height + crown + SitelD & 5 & 1104.60 & 9.44 & 0.004 \\
\hline Cat density + SitelD & 4 & 1104.95 & 9.79 & 0.003 \\
\hline DistKWS + SitelD & 4 & 1105.32 & 10.16 & 0.003 \\
\hline Tree height + crown $+($ elevation * TOPEX $)+$ SiteID & 8 & 1105.35 & 10.19 & 0.003 \\
\hline Tree height + SitelD & 4 & 1105.68 & 10.52 & 0.002 \\
\hline (Tree height $*$ crown) + elevation + SiteID & 7 & 1105.86 & 10.70 & 0.002 \\
\hline Exotic conifers + SitelD & 4 & 1105.95 & 10.79 & 0.002 \\
\hline Exotic.100 + SitelD & 4 & 1105.98 & 10.82 & 0.002 \\
\hline Exotic. $200+$ SitelD & 4 & 1105.98 & 10.82 & 0.002 \\
\hline Tree height + crown + elevation + TOPEX + distKWS + emergent + SiteID & 9 & 1106.13 & 10.98 & 0.002 \\
\hline Tree height + crown + elevation + SitelD & 6 & 1106.41 & 11.26 & 0.002 \\
\hline (Tree height * crown) + elevation + TOPEX + distKWS + emergent + SiteID & 10 & 1106.97 & 11.82 & 0.001 \\
\hline (Tree height * crown) + elevation + TOPEX + SiteID & 8 & 1107.07 & 11.92 & 0.001 \\
\hline Dog density + SitelD & 4 & 1107.10 & 11.95 & 0.001 \\
\hline Exotic. 100 + distKWS + SitelD & 5 & 1107.38 & 12.22 & 0.001 \\
\hline Exotic.200 + distKWS + SitelD & 5 & 1107.40 & 12.24 & 0.001 \\
\hline Tree height + crown + elevation + TOPEX + SiteID & 7 & 1107.42 & 12.26 & 0.001 \\
\hline
\end{tabular}

Table continued on following page 


\begin{tabular}{lcccc}
\hline Models & $\boldsymbol{K}$ & AICc & \multicolumn{1}{c}{$\Delta$ AICc } & $\boldsymbol{\omega}$ \\
\hline Cat density + dog density + urban density + distKWS + SitelD & 7 & 1107.60 & 12.44 & 0.001 \\
Exotic conifers + exotic.200 + SitelD & 5 & 1107.86 & 12.70 & 0.001 \\
Cat density + dog density + SitelD & 5 & 1108.25 & 13.09 & 0.001 \\
(Tree height * crown) + elevation + TOPEX + distKWS + SiteID & 9 & 1108.32 & 13.17 & 0.001 \\
Cat density + dog density + urban density + SitelD & 6 & 1108.38 & 13.22 & 0.001 \\
Tree height + crown + elevation + TOPEX + distKWS + SitelD & 8 & 1109.03 & 13.88 & 0.000 \\
Exotic conifers + exotic.200 + distKWS + SitelD & 6 & 1109.24 & 14.08 & 0.000 \\
(Cat density + dog density) * urban density + distKSW + SitelD & 9 & 1109.91 & 14.75 & 0.000 \\
(Cat density + dog density) * urban density + SitelD & 8 & 1110.75 & 15.60 & 0.000 \\
\hline
\end{tabular}

\section{Key:}

distKWS: distance to nearest KWS boundary

distfgs: distance to nearest forested greenspace

sizefgs: size of nearest forested greenspace

TOPEX: topographical exposure score

crown: tree crown size

emergent: number of trees above eave line

Native.100: area of native vegetation within $100 \mathrm{~m}$

Native.200: area of native vegetation within $200 \mathrm{~m}$

Exotic.100: area of exotic vegetation within $100 \mathrm{~m}$

Exotic.200: area of exotic vegetation within $200 \mathrm{~m}$

Feeders: number of feeders per site 
Table 2.5: The candidate set of 48 linear mixed-effect models as hypotheses for the drivers of resource selection by visiting group size of kākā, reported by Wellington City residents on their properties. Models are displayed in descending order of likelihood, ranked by second order Akaike's Information Criterion score $(\triangle \mathrm{AICc})$ and Akaike weights $(\omega)$. The number of parameters in each model are also shown $(K)$. The number of respondents in the sample $(n)$ is 301 . Models with $\triangle$ AICc scores $<2$ have substantial support. Scores of $<10$ indicate plausible models and $>10$ are implausible models.

\begin{tabular}{|c|c|c|c|c|}
\hline Models & $K$ & AlCc & $\triangle \mathrm{AICc}$ & $\boldsymbol{\omega}$ \\
\hline Feeders + SitelD & 4 & 886.82 & 0.00 & 0.427 \\
\hline Feeders + distKWS + SitelD & 5 & 887.57 & 0.76 & 0.293 \\
\hline Feeders + distKWS + urban density + SiteID & 6 & 890.08 & 3.26 & 0.084 \\
\hline Feeders + distKWS + urban density + (feeders * distKWS) + SiteID & 7 & 890.98 & 4.17 & 0.053 \\
\hline Native. $200+$ SitelD & 4 & 891.59 & 4.77 & 0.039 \\
\hline Native.100 + SiteID & 4 & 893.58 & 6.76 & 0.015 \\
\hline Pohutukawa + native. 100 + SitelD & 5 & 893.91 & 7.09 & 0.012 \\
\hline Distfgs + sizefgs + SitelD & 5 & 894.47 & 7.65 & 0.009 \\
\hline Native. 200 + distKWS + SitelD & 5 & 894.87 & 8.05 & 0.008 \\
\hline Cat density + SitelD & 4 & 895.02 & 8.21 & 0.007 \\
\hline Urban density + SitelD & 4 & 895.27 & 8.46 & 0.006 \\
\hline Native.100 + distKWS + SiteID & 5 & 896.21 & 9.39 & 0.004 \\
\hline (Tree height $*$ crown) + SitelD & 6 & 896.24 & 9.42 & 0.004 \\
\hline Tree height + crown + emergent + SitelD & 6 & 896.40 & 9.58 & 0.004 \\
\hline Distfgs + SitelD & 4 & 896.41 & 9.59 & 0.004 \\
\hline SitelD & 3 & 896.46 & 9.64 & 0.003 \\
\hline Pohutukawa + SitelD & 4 & 896.78 & 9.96 & 0.003 \\
\hline Pohutukawa + native. 100 + distKWS + SiteID & 6 & 896.99 & 10.17 & 0.003 \\
\hline Tree height + crown + SitelD & 5 & 897.04 & 10.23 & 0.003 \\
\hline (Tree height $*$ crown $)+$ emergent + SitelD & 7 & 897.12 & 10.30 & 0.002 \\
\hline Distfgs + sizefgs + distKWS + (distfgs * sizefgs $)+$ SiteID & 7 & 897.43 & 10.61 & 0.002 \\
\hline Distfgs + sizefgs + distKWS + SitelD & 6 & 897.51 & 10.69 & 0.002 \\
\hline Pohutukawa + native. 100 + distKWS + (pohutukawa * native.100) + SiteID & 7 & 897.73 & 10.92 & 0.002 \\
\hline Cat density + dog density + urban density + SitelD & 6 & 897.93 & 11.12 & 0.002 \\
\hline Tree height + SitelD & 4 & 898.74 & 11.92 & 0.001 \\
\hline Cat density + dog density + SitelD & 5 & 898.93 & 12.11 & 0.001 \\
\hline$($ Tree height $*$ crown $)+($ elevation $*$ TOPEX $)+$ SitelD & 9 & 899.12 & 12.30 & 0.001 \\
\hline (Tree height $*$ crown $)+$ elevation + SitelD & 7 & 899.18 & 12.36 & 0.001 \\
\hline Exotic conifers + SitelD & 4 & 899.41 & 12.59 & 0.001 \\
\hline DistKWS + SitelD & 4 & 899.42 & 12.61 & 0.001 \\
\hline Exotic. $100+$ SitelD & 4 & 899.47 & 12.65 & 0.001 \\
\hline Exotic. $200+$ SitelD & 4 & 899.52 & 12.70 & 0.001 \\
\hline Cat density + dog density + urban density + distKWS + SiteID & 7 & 899.77 & 12.95 & 0.001 \\
\hline Tree height + crown + elevation + SitelD & 6 & 899.85 & 13.03 & 0.001 \\
\hline Dog density + SitelD & 4 & 900.18 & 13.36 & 0.001 \\
\hline Tree height + crown $+($ elevation * TOPEX $)+$ SitelD & 8 & 901.30 & 14.48 & 0.000 \\
\hline (Tree height $*$ crown $)+$ elevation + TOPEX + SiteID & 8 & 901.76 & 14.94 & 0.000 \\
\hline Tree height + crown + elevation + TOPEX + SitelD & 7 & 902.17 & 15.35 & 0.000 \\
\hline Exotic conifers + exotic $200+$ SitelD & 5 & 902.33 & 15.51 & 0.000 \\
\hline
\end{tabular}

Table continued on following page 


\begin{tabular}{lcccc}
\hline Models & $\boldsymbol{K}$ & AICc & $\boldsymbol{\Delta A I C c}$ & $\boldsymbol{\omega}$ \\
\hline Exotic.100 + distKWS + SitelD & 5 & 902.36 & 15.54 & 0.000 \\
Exotic.200 + distKWS + SitelD & 5 & 902.43 & 15.61 & 0.000 \\
(Cat density + dog density) * urban density + SitelD & 8 & 902.95 & 16.14 & 0.000 \\
Tree height + crown + elevation + TOPEX + distKWS + emergent + SiteID & 9 & 903.85 & 17.03 & 0.000 \\
(Cat density + dog density) * urban density + distKSW + SiteID & 9 & 904.76 & 17.95 & 0.000 \\
(Tree height * crown) + elevation + TOPEX + distKWS + SitelD & 9 & 904.78 & 17.96 & 0.000 \\
Tree height + crown + elevation + TOPEX + distKWS+ SiteID & 8 & 905.10 & 18.28 & 0.000 \\
(Tree height * crown) + elevation + TOPEX + distKWS + emergent + SitelD & 10 & 905.17 & 18.35 & 0.000 \\
Exotic conifers + exotic.200 + distKWS + SiteID & 6 & 905.19 & 18.37 & 0.000 \\
\hline
\end{tabular}

\section{Key:}

distKWS: distance to nearest KWS boundary

distfgs: distance to nearest forested greenspace

sizefgs: size of nearest forested greenspace

TOPEX: topographical exposure score

crown: tree crown size

emergent: number of trees above eave line

Native.100: area of native vegetation within $100 \mathrm{~m}$

Native.200: area of native vegetation within $200 \mathrm{~m}$

Exotic.100: area of exotic vegetation within $100 \mathrm{~m}$

Exotic. 200: area of exotic vegetation within $200 \mathrm{~m}$

Feeders: number of feeders per site 


\subsection{Discussion}

\subsubsection{Factors affecting distribution}

Residential feeding was found to be the strongest driver of kākā presence on residential properties. While feeding by itself is a strong driver of overall abundance, the importance of feeders is particularly evident in the strong weighting the variable also has on visiting frequency and group size, compared to other models in their respective sets. These models indicate that kākā visiting frequency and group size on properties are strongly influenced by the number of feeders in the vicinity. The interaction of feeders and distance to KWS is also a strong variable explaining overall abundance of kākā on properties. However, this appears to be driven by only two sites. The two sites which had the most feeders, also happened to be the two sites closest to the sanctuary, approximately 50m and $100 \mathrm{~m}$ from the nearest KWS boundary. Outside of these two sites, there appeared to be no significant relationship with kākā presence as the distance from the sanctuary increased (Figure 2.2). This is reflected in the poor weighting of the distKWS variable outside of its connection to feeding, with kākā presence not changing significantly between distances of 500m to 4000m away from KWS

Urban density features in the leading models, but its relationship with kākā abundance was weak and on its own it performed poorly as a predictor. Nonetheless, it is likely that larger suburban lots have more space for vegetation to grow, especially the taller, large trees with larger crowns that others have found are favoured by kākā (Charles and Linklater, 2014). Larger lots are also more likely to be associated with more exposed sites at higher altitude and proximity to unbuilt habitat such as tracts of native vegetation (the city is centred and built on lower lying, gentler slopes) that have also previously been identified as important to kākā (Charles and Linklater, 2014; Recio et al, 2016). These features of the environment can be seen in the other plausible models ranked after those with feeding, as they contained variables related tree and crown size, number of emergent trees, proximity to 
native vegetation, elevation and topographical exposure. Urban density appears to be a metric that serves to represent those other features of the vegetated and physical environment. While these predictors and urban density may not be the best explanation for kākā presence in this model set, in the potential absence of residential feeders, they are likely to have a more significant influence on kākā's habitat choices. City planners can use this to create greenspaces with increased emphasis on large tree species, which can act as suitable habitat for kākā inside the city as the population grows.

While my mixed model inference and selection suggests the most suitable factors affecting the response variable, it also gives reasonable indication as to what factors do not. Neither the presence of exotic conifers nor the area of exotic green space proximal to sites appeared to be significant in driving overall kākā abundance, visiting frequency or visiting group size. The finding that exotic conifers were poor predictors is surprising, as Charles and Linklater (2014) found that large exotic conifers in exposed and elevated locations were preferred in tree selection for sap feeding around Wellington City. While important, sap feeding consists of only a portion of a kākā's broad diet (O'Donnell and Dilks, 1994; Moorhouse, 1997) It is possible that kākā prefer exotic conifers for sap feeding specifically and native vegetation for other nutritional requirements. The other significant variables in Charles and Linklater (2014) were tree diameter at breast height (DBH), topographical exposure and elevation. While exotic conifers were not found to be significant in this empirical chapter, some models consisting of tree size (represented by tree height and crown size), topographical exposure and elevation variables were found to be plausible when explaining overall abundance. These variables were less prevalent in affecting visiting frequency or group size.

While knowledge of kākā breeding behaviour in urban environments is limited, it can be expected that high domestic predator density can discourage nesting nearby and therefore 
reduce the presence of kākā. It has been shown that dogs can act as deterrents to general bird life (Banks and Bryant, 2007) so it can be possible that they will have the same effect on kākā. Cats can pose a threat to eggs and fledglings in kākā nest cavities, just as they prey on other urban birds (Baker et al, 2005; Kikillus et al, 2017). However, my findings suggest that the presence of domestic cats and dogs on properties have relatively little impact on kākā presence. The strongest models for these variables across all three model sets was the density of cats by itself. However, these models were only just plausible, with $\Delta \mathrm{AICc}$ scores of $>8$ and $<10$ and were weighted poorly (Table 2.3; Table 2.4; Table 2.5).

\subsubsection{Relation to previous studies}

These findings build on those by Recio et al, (2016) who found that kākā selected proximity to native forest patches and urban areas close to KWS. They also suggested that the selection of space close to urban areas could be influenced by residential feeders. The findings of this chapter reflected this, as the two sites with the highest kākā abundance were closest to the sanctuary and they also had the two highest numbers of feeders per site (five and seven). While not as powerful as models containing feeders, proximity to native forest was also a plausible factor. Where this thesis' findings go further, is it shows that outside these two extremely proximal sites, there is no significant relationship between distance and kākā abundance. While lower than the closest two sites, kākā abundance at sites approximately 500m away had similar levels of kākā presence to those 4000m away (Figure 2.2). This indicates that as time goes on, kākā have spread further into Wellington suburbs and may not be so reliant on the sanctuary. The kākā used by Recio et al, (2016) were captured either inside KWS, or at nearby residences, suggesting that kākā residing inside the sanctuary appear to use the proximal urban space. However, this chapters' findings suggest that while this is still true, there may also be individuals that have established home ranges in locations 
further out into the suburbs, influenced by native forest patches and residential feeders. The use of GPS telemetry on kākā caught further away from KWS may more accurately test these findings.

\subsubsection{Anthropogenic waste as a food source}

As well as intentional backyard feeding, unintentional feeding in the form of anthropogenic food waste is also present in urban environments. Both birds and mammals have been observed to be attracted to and utilise sources of waste in residential areas. Silver gulls (Larus novaehollandiae) have been observed frequenting rubbish tips across urban Melbourne, Australia (Temby, 2004). These sources have allowed the gull population in Melbourne to increase significantly, leading to several issues such as noise, fouling and nesting blocking drains. Garbage in some suburbs across the North-west United States also attract black bears (Ursus americanus). This attraction has led to increases in interactions between the bears and people, creating opportunities for conflict (Beckmann and Berger, 2003). A closely relatedly parrot, the Kea (Nestor notabilis) has also been found to easily utilise refuse sources (Diamond and Bond, 1999). Kea were observed congregating and foraging at Halpin Creek rubbish dump in Arthur's Pass, New Zealand (Jarret and Wilson, 1999). While juvenile individuals used the source seasonally, some adults were found to be present year-round, suggesting that they became habituated.

There have yet been no notable anecdotal or empirical reports of this behaviour occurring in kākā in Wellington City. However, the attraction of kākā to residential feeders shown in this chapter suggests that developing this behaviour of seeking out food in urban waste sources such as rubbish bins cannot be discounted in future. If kākā become habituated to intentional residential feeding, it is possible that they can seek out other anthropogenic sources. Furthermore, kākāa, particularly juveniles, demonstrate cognitive intelligence and 
problem-solving ability (Leopelt et al, 2016) which may help them to exploit anthropogenic waste sources such as garbage and compost bins. This learned behaviour can be seen at the artificial feeding stations inside KWS, which require kākā to actively step onto a metal plate to lift a lid, which gives access to the supplementary food inside.

Regularly accessing waste sources alongside residential feeders may have ecological and biological consequences for kākā. Food available in anthropogenic waste may provide insufficient nutrients for kākā and lead to a decline in chick health. Social complications such as conflict involving people may also arise from increased human interactions, as was present with silver gulls and black bears (Beckmann and Berger, 2003; Temby, 2004). 


\subsection{Conclusion and recommendations}

Residential feeding appears to be the main predictor influencing kākā presence on residential properties in Wellington City. All the models containing the 'feeders' variable were present in confidence sets for total abundance, visiting frequency and group size. However, an interaction with the number of feeders and the distance to KWS was the greatest driver of abundance. The highest kākā abundances occurred on the two sites with the most feeding residents but were also the two sites closest to the sanctuary. Implausible models included variables such as cat and dog density at a site, proximity of exotic vegetation and presence of exotic conifers. As this population of kākā grows, concentrations of kākā around areas of anthropogenic feeders may increase. Habituation to these anthropogenic sources can potentially lead to kākā also using human refuse sources such as rubbish bags and bins. Monitoring and enforcing resident behaviour, such as feeding, on private property is difficult. I recommend government and council bodies monitor the continued growth of this population and their preferred habitat choices. Should residential feeding continue to be a main driver in its habitat choice and problems arise from this, discouraging feeding through various mediums should be considered. 


\section{Chapter Three: Wild parrot feeding, damage and the attitudes of}

\section{Wellington City residents.}

\subsection{Introduction}

The practice of reintroducing wildlife into areas proximal to humans has become more common (van Heezik and Seddon, 2018; Linklater et al, 2018), increasing the presence of wildlife in cities. However, just as landscapes have an ecological carrying capacity to support wildlife populations, urban environments also have a social carrying capacity (Minnis and Peyton, 1995; Conover, 2001). Social carrying capacity is the limit imposed by a society’s tolerance of a wildlife population. Among people living in cities, there is large variation in individual tolerances towards wildlife and in their perceptions of what constitutes acceptable levels of wildlife impact (Marchini, 2014). However, if problems caused by wildlife are widespread and severe enough, they may exceed the tolerance levels of the community as a whole, and force wildlife conservation managers to act.

Feeding wildlife in urban environments is an easy and common way that people form a relationship with wildlife, particularly birds (Galbraith et al, 2014; Cox and Gaston, 2016). While there are benefits to feeding avifauna, either intrinsically for people or ecologically for bird species (Whitburn et al. 2008; Cox and Gaston, 2016), there are also risks and consequences associated with it. These include the increased risk of transmitting avian diseases, increasing the dependency of wild birds on anthropogenic food sources and changing the species composition of avian assemblages (Galbraith et al, 2014; Reynolds et al, 2007; Fuller et al, 2008). Avifauna behaviour in urban environments can also cause problems such as nesting in roofs, odour, noise, and harassment of people (Charles and Linklater, 2013). Residential feeding can increase the opportunities for these problems to lead 
to conflict with people, by increasing the density of birds in areas of feeders and increasing the interaction rate between people and avifauna (Belant,1997; Solsbury and White, 2016; Linklater et al, 2018). While the problems involving avifauna and feeding have been well documented, there is currently a paucity of empirical evidence suggesting residential feeding leads to property damage. However, recent empirical work has shown that kākā, a parrot native to New Zealand, damages public and residential properties in urban environments (Charles 2013, Charles and Linklater, 2013, Linklater et al, 2018). Residential feeders have been observed to increase the concentration of wildlife at a localised area (Fuller et al, 2008). Therefore, feeding kākā on a property may increase their presence, and consequently increase the likelihood of damage to it and the surrounding properties. It is imperative then, that this possible relationship between feeding and damage be investigated.

Wildlife can damage a wide range of assets valued by humans, including agricultural crops, livestock, private property, and natural resources as well as impacting human wellbeing (Bangs and Shivik, 2001; Hedges and Gunaryadi, 2010; Redpath et al, 2015; Hygnstrom et al, 2014). Wildlife damage is a common driver of conflict involving people and wildlife, as it devalues assets that may have financial or sentimental value to an individual or group of people. People's responses to damage may vary considerably due to a wide range of influencing factors such as wealth, education and their existing experience with nature, all of which influence how individuals perceive wildlife and its associated problems (Sasidharan and Thapa, 2004; Dickman, 2010; Soulsbury and White, 2016). This is more apparent in urban environments where people with a diversity of different cultural beliefs and personal attitudes live at high densities (Soulsbury and White, 2016).

While urban wildlife conflict has been rare in New Zealand, the localised conflict involving kākā in Wellington City is growing. Since their reintroduction in 2002, kākā presence on residential properties and the subsequent interactions with people has become 
common. This interaction on residential properties has had a polarising effect among residents. Many enjoy the kākā's presence on their properties, with some even feeding kākā to further encourage their presence (Charles, 2013; Linklater et al, 2018). However, some residents do not appreciate kākā near or on their property. Empirical studies and anecdotal evidence have shown that kākā cause damage to residential properties. This damage occurs primarily on trees, when they remove bark in search of tree sap or wood-boring insects (Charles and Linklater, 2013). Bark and phloem damage can have significant consequences for tree health. Eucalyptus spp. exhibiting kākā damage have been observed showing signs of physiological stress such as epicormic growth (Charles, 2012). Epicormic growth is characterised by rapid shoot elongation with little secondary growth, resulting in a weaker branch structure. In backyards, weaker tree limbs pose a hazard to residents. Damage to trees can also cause crown dieback (Innes, 1994) and increases a tree's susceptibility to pathogens (Beavan, 1996). In severe cases these consequences can result in tree mortality and requires its removal. Kākā have also been known to damage other parts of property such as roofing, external building cladding and outdoor furniture (Charles, 2013, Charles and Linklater, 2013, Linklater et al, 2018). This damage is likely to be a driving factor in much of the conflict involving kākā and the residents of Wellington City, as it negatively affects residents' personal assets. However, property damage is likely to affect residents differently. Those residents with an existing positive relationship with kākā may be more tolerant of the damage, as they believe the intrinsic benefits of having kākā outweigh any negatives. Much of the damage to residential properties stems from kākā's natural feeding behaviour, and as such, cannot be changed. However, understanding what external factors cause or exacerbate the damage by kākā and how this damage affects attitude towards kākā and wildlife in general, will help implement strategies to mitigate conflict.

This empirical chapter investigates the extent of the direct impact that kākā have on urban residents through their behaviour on residential properties, and how this interaction 
affects residents' attitudes towards kākā specifically and avian conservation in general. It does this through asking two questions. The first question asks; what factors best explain the presence and extent of damage on residential properties? I hypothesize that residential feeding and the frequency with which kākā visit properties contribute most towards damage on residential property. The second question asks; how does this damage to private property impact residents' attitudes towards kākā? I hypothesise that as overall damage increases, resident attitude scores will decrease. Residents who have damage on their house or building surfaces will also have lower attitude scores than those with damage to trees. Also, as the cost of repairing damage increases, I expect attitude scores to decrease. Within these overall responses, I hypothesise that residents who feed, will have higher attitude scores than those that do not. 


\subsection{Methods}

\subsubsection{Survey design and distribution}

A postal survey was used to gain an understanding of residents' experience with kākā on their properties, including their opinions about property damage by kākā. This survey was the same as described in Chapter 2 [Appendix 3] and similar to another survey conducted on residential attitudes towards kākā and reported in Linklater et al (2018) [Appendix 4]. Of the 14 questions, 11 asked residents about kākā. Questions were asked about the frequency with which kākā visited properties and the average number of birds that visited at a time, residents feeding kākāa, and to what extent kākā damaged the resident's properties. Respondents were asked to categorise their answers to questions about kākā presence, residential feeding and damage on ordinal scales. Residents were then invited to give further detail into the specific nature of the damage if any, what they have done to repair or fix it, and how much it cost them.

To gain an understanding of the residents' attitude toward avian wildlife and kākā specifically, a series of seven attitudinal statements were used. The respondent was asked to give weight to these statements on a Likert scale from one to five with five being strongly agreeing with the statement and one strongly disagreeing with it (Boone and Boone, 2012). All seven statements except number six were worded so that higher responses coincided with more positive attitudes. When analysing the data, responses to statement six were inverted to also indicate this. These scores could then be used to compare against several other variables that may influence attitude such as feeding, kākā presence and damage. Lastly, three questions about the respondents' gender and age, and house ownership were also asked. Answers were also categorical, where respondents only had to select relevant boxes. 
As previously described in Chapter Two, the surveys were distributed to 600 households at 25 randomly chosen sites throughout Wellington City's suburbs (Figure 1.1). Surveys were posted to 24 residences at each site. Introductory and reminder letters were sent prior to and following the surveys respectively. Information sheets and freepost envelopes accompanied the surveys.

Two versions of the survey were distributed to households. They both included the same questions, however in 192 of the surveys to eight of the 25 neighbourhoods the questions regarding attitude were asked first, before the questions regarding kākā abundance and damage on residents' properties. In the more common survey, kākā abundance and damage are $\mathrm{Qu}$ 1-2 and 6, while the attitude statements are $\mathrm{Qu}$ 11. In the alternative version of the survey, the attitude statements are $\mathrm{Qu} 1$. The purpose of changing the order of the questions was to detect any reporting biases in attitude towards kākā and wildlife as a response to the primary attitude modifiers, damage and kākā presence.

\subsubsection{Data treatment}

The returned surveys were pooled with the returned surveys used in Linklater et al, (2018). The two surveys were identical but for minor changes in the attitude statement scales. This survey used 1 to represent a strong agreement and 5 a strong disagreement. All attitude scores were inverted to match this thesis' data. Both surveys had the same number of questions and topics. The raw survey results were included in this study to increase the sample population size.

Kākā damage at a property was measured using two metrics. One, an overall total damage score reported by the resident, and two, a binary presence/absence metric. A binary presence or absence score was used to test what factors were important for explaining the occurrence of damage. To gain an index of overall damage at a property, the residents were asked to rank the damage to their property from zero to five across each of four types of 
damage: roofing, other building surfaces, trees and 'other'. A zero indicated no damage, a one was given for minor damage, through to five for severe damage. These scores were summed, giving a possible score range of 1 to 20 .

Damage type was a categorical variable, determined by what part of the residence was damaged by kākā. These were no damage, house only, trees only and both house and trees. The financial cost of repairs to fix kākā damage was given an ordinal scale. No cost towards repairs was scored a $0, \$ 1-\$ 50$ was scored a $1, \$ 51-\$ 200$ scored a 2 , and $>\$ 200$ scored a 3. Cost ranges were chosen so that group sizes would be as even as possible for statistical power.

Feeding behaviour was a binary categorical variable, either feeding or not feeding kākā. Several aspects of residential feeding were also explored. Initially residents were placed in two nominal categories; those that did not feed kākā, and those that did feed. These were given representations of zero and one respectively. Next, the proximity to a feeder was considered. This again was split into two nominal categories. Feeders and neighbours of feeders were given a one, while other residents were given a zero. Residents were considered neighbours of feeders if they were within two properties either side of a feeder or had an overlapping berm with a feeder across the street.

The frequency with which residents fed kākā was measured ordinally. The five ranked categories (once a year, once a month, once a week, >once a week, >once a day) given to residents in the survey were assigned an integer from one to five. Feeding once a year scored a one, while feeding more than once a day was given a five. The number of feeders at each of the 33 sites were also included as discrete continuous variables.

The distance from the sanctuary is investigated as a factor that increases property damage by kākā due to the artificial feeders for kākā situated inside KWS and because it was the reintroduction site. The distance measured (in metres) was from the centre of each study site to the point on the sanctuary border closest to it. This was measured electronically on the 
computer through the Google Maps ruler function. As the scale of these data was much different to the other variables, the variable was centred using methods from Gelman and Hill (2012). The formula $(x-\bar{x}) / 2 \sigma$ was used, where $x$ is each entry of the variable from each site and $\bar{x}$ is the variable mean.

Kākā abundance was measured as a combination of visiting frequency and average visiting group size. These two components were measured using the same methods outlined in Chapter Two, Section 2.3. Survey design and questions.

\subsubsection{Statistical analysis}

To investigate whether question order had any effect on a resident's attitude, the attitude response scores from the normal and alternate surveys were compared. The alternate question survey contained the exact same questions as the normal, however the alternate survey had the attitude questions placed before the questions asking about kākā abundance and damage.

To test if a difference in attitude was present, the attitude responses to each statement from every resident across the two different surveys was compared. A resident's survey type was denoted as either a 0 for normal, or 1 for the alternate survey. A random effect for both site and resident was used in this model. This was analysed using a repeated measure, oneway, mixed model ANOVA, using the free, open-source R 3.5.1 base software.

A test was then carried out to see if there was a difference in attitude due to an interaction between the question order and whether the resident fed kākā. Residents were identified by survey type using a 0 or 1 as before, and by feeding behaviour using a 0 for nonfeeders and a 1 for feeders. Again, each resident's individual Likert scores to the seven statements were analysed. A repeated measures, one-way ANOVA was used to test the 
difference in means between the two feeding groups and survey types. This was also carried out using the R 3.5.1 software and the carData 3.0.2 package (Fox et al, 2018).

An information theoretic approach was used to gain a best explanation as to what factors lead to kākā damaging residential properties. A combination of a priori information and new hypotheses were used to create a candidate set of 22 models with seven fixed-effect variables and one random-effect (Table 3.1). Second order Akaike's Information Criterion (AICc) was used to compare log likelihood of each model using linear mixed model regression. This procedure was carried out using R 3.5.1 software and the multi model inference package, MuMIn (Barton, 2018).

As each site was surveyed multiple times, the random effect of site was used to test if there was any systematic variance between sites that wasn't explained by the fixed effects. This variable, represented by SiteID, was added to every model and tested as a model by itself. 
Table 3.1: Table of hypotheses explaining kākā damage on residential properties with candidate set of 22 models.

\begin{tabular}{|c|c|}
\hline Hypotheses & Models \\
\hline $\begin{array}{l}\text { Damage is reported differently by } \\
\text { neighbourhoods and more similarly among } \\
\text { neighbours than neighbourhoods. }\end{array}$ & SitelD (random effect) \\
\hline $\begin{array}{l}\text { Damage is reported differently by feeders (they } \\
\text { have a different and pre-existing relationship } \\
\text { with kākā than others). }\end{array}$ & Feeder + SitelD \\
\hline $\begin{array}{l}\text { Kākā damage is due to proximity to } \\
\text { reintroduction site and its support }\end{array}$ & Feeder + distKWS + SitelD \\
\hline $\begin{array}{l}\text { Kākā are the primary cause of damage- the } \\
\text { more there are, the more damage there is } \\
\text { (without recourse to feeding). }\end{array}$ & $\begin{array}{l}\text { Feeder + group size + SitelD } \\
\text { Feeder + kākā freq + SitelD } \\
\text { Feeder + kākā freq + group size + SiteID } \\
\text { Feeder + kākā freq + group size + distKWS + SitelD } \\
\text { Feeder + kākā freq + group size + distKWS + (kākā freq * group size) + SiteID } \\
\text { Feeder + kākā freq + group size + distKWS + (kākā freq * group size * distKWS + SiteID }\end{array}$ \\
\hline $\begin{array}{l}\text { Kākā damage is due to feeding } \\
\text { a. Just or mainly neighbourhood feeding }\end{array}$ & $\begin{array}{l}\text { Feeder + Feeder proximity + SitelD } \\
\text { Feeder + Feeder proximity + Feeding freq + SitelD } \\
\text { Feeder + Feeder proximity + Feeding freq + Feeders per site + SitelD } \\
\text { Feeder + Feeder proximity + Feeding freq + Feeders per site + (Feeder proximity * Feeding freq })+ \\
\text { SitelD } \\
\text { Feeder + Feeder proximity + Feeding freq + Feeders per site + (Feeder proximity * Feeders per site })+ \\
\text { SitelD } \\
\text { Feeder + Feeder proximity + Feeding freq + Feeders per site + (Feeder proximity * Feeding freq * } \\
\text { Feeders per site) + SitelD }\end{array}$ \\
\hline
\end{tabular}

Table continued on following page 


\section{Hypotheses}

b. Including reintroduction site feeding (and other forms of support)

\section{Models}

Feeder + Feeder proximity + distKWS + SiteID

Feeder + Feeder proximity + Feeding freq + distKWS + SiteID

Feeder + Feeder proximity + Feeding freq + Feeders per site + distKWS + SiteID

Feeder + Feeder proximity + Feeding freq + Feeders per site + distKWS + (Feeder proximity * Feeding

freq) + SitelD

Feeder + Feeder proximity + Feeding freq + Feeders per site + distKWS + (Feeder proximity * Feeding freq $*$ Feeders per site) + SitelD

Feeder + Feeder proximity + Feeding freq + Feeders per site + distKWS + (Feeder proximity * Feeders per site + SitelD

Feeder + Feeder proximity + Feeding freq + Feeders per site + distKWS + (Feeder proximity * Feeding freq $*$ Feeders per site $*$ distKWS) + SitelD

\section{Key:}

Feeder: whether the respondent is feeds kākā or not

Feeder proximity: whether the respondent was a neighbour or not

Feeders: number of feeders per site

distKWS: distance to nearest KWS boundary

Feeding freq: how often a resident fed kākā

Kākā freq: visiting frequency

SiteID: random variable for site 
It was then investigated whether the damage from kākā on residents' properties had an influence on attitudes towards both kākā and wildlife in general. Three aspects of damage were explored; where the damage occurred on the property, how much residents spent on repairing damage and an overall damage score. Whether a resident was a feeder or not was included in the analysis. Initially, this was to determine if feeders have a different attitude from those residents that do not feed. Furthermore, it was to test if feeders and non-feeders have different attitudes when there is also property damage present.

An information theoretic approach was used to determine whether the random effect for site, resident, or both was best used to explain any unobserved variation either within the sites, or residents. Three additive, linear mixed effects models were used to test the three random effects. Second order Akaike's Information Criterion was used to compare the log likelihood of each model using linear mixed model regression. This was carried out using $\mathrm{R}$ 3.5.1 software and the multi model inference package, MuMIn (Barton, 2018).

A repeated measures, one-way ANOVA was used to test the individual attitude scores against the four fixed-effects variables. A linear mixed-effects model with additive fixed and random effects was initially used in this analysis. These variables were tested seven times for each resident, (one for each attitude statement) across all 611 residents. A Kruskal Wallace test was used to determine which statements had groups that differed significantly. A Dunn's test was used to identify with of the cost groups within each statement differed significantly from the others.

It was then tested whether attitudes towards damage changed depending on whether the resident fed kākā. The feeder fixed effect was tested in an interaction with total damage, and then repair cost. This used the same linear mixed-effects model with additive fixed and random effects but included in the model was an interaction term between feeder status and 
either overall damage or repair cost. This analysis was carried out using R 3.5.1 software and the carData 3.0.2 package (Fox et al, 2018).

An information theoretic approach was then used to determine if the factors causing damage on residential properties could better explain attitudes than those tested above. Three models were used; the best two models explaining damage and the best to be found explaining attitude variation. Second order Akaike's Information Criterion was again used to test the log likelihood of each of the three mixed models. R 3.5.1 software and the multi model inference package, MuMIn (Barton, 2018) was used for this analysis. 


\subsection{Results}

Of the 600 surveys delivered to residential households, 309 were returned (52\%). Eight returned surveys could not be used because they were incomplete. The remaining 301 surveys were supplemented with a further 310 similar returned surveys (55\%) reported in an earlier study (Linklater et al, 2018) for a total of 611 surveys.

Females were $354(57.9 \%)$ of respondents (male: 252 or $41.2 \%)$. There was a significant difference between the sex composition of respondents and that of Wellington City. A significantly higher proportion of females responded to the surveys than those present in Wellington City (Stats NZ, 2013) $(Z=3.14, P=<0.0008)$. Three surveys were answered by a male-female couple and two respondents identified their gender as 'Other'. Most surveys ( 314 or $51 \%$ ) were answered and returned by middle-aged ( 41 to 65 years old) residents: $<25$ years old $(23,4 \%), 26-40(131,21 \%), 65+(144,24 \%)$. A significantly higher proportion of residents between ages 41-65 were sampled by the survey than are present in Wellington City as of the 2013 census $(Z=4.955, P=<0.0001)$. Also, a significantly higher proportion of residents over 65 years old were sampled by the survey than are present in Wellington City as of the 2013 census $(Z=8.052, P=<0.0001)$.

Kākā were reported to have been present at 426 properties $(69.7 \%)$. Mean $( \pm 1 \mathrm{SE})$ visiting frequency was $2.84 \pm 0.07$ (range of 1 to 5 ) and mean group visiting size was $2.18 \pm$ 0.05 (range of 1 to 6 ). The mean total kākā abundance was $5.02 \pm 0.11$ (range of 2 to 11).

Forty-two residents $(\sim 7 \%)$ reported feeding kākā in their backyards and 93 (15.2\%) reported property damage that they attributed to kākā. Their mean scores for total property damage were $3.57 \pm 0.30$ (range 1 to 17 , where the maximum score possible was 20 ). Seventeen $(18 \%)$ of respondents that reported damage also reported that they had repaired the damage and incurred an associated financial cost. The mean financial expenditure was $\$ 722 \pm$ 
346 , with a median value of $\$ 100$. The minimum cost to repair or prevent damage was $\$ 8.00$ for netting over apple trees, while the most was approximately $\$ 6000$ to replace and repaint exterior wall cladding.

The mean total attitude score, summed from all seven attitude statements, was $29.19 \pm$ 0.19 (range of 12 to 35$)$. The mean attitude scores $( \pm 1 \mathrm{SE}$, range of 1 to 5$)$ for each statement were; (1) Native birds are an asset to our city: $4.84 \pm 0.02$, (2) Native wildlife deserves to be protected : $4.81 \pm 0.02$, (3) You enjoy seeing kākā in your neighbourhood: $4.53 \pm 0.03$, (4) Kākā have a right to live in our city: $4.25 \pm 0.04$, (5) You want to see more kākā in your neighbourhood: $4.11 \pm 0.05$, (6) Kākā should be managed if they cause problems: $2.76 \pm$ 0.05, (7) People should tolerate kākā regardless of the problems caused: $3.88 \pm 0.05$.

\subsubsection{Causes of property damage}

Of the 22 models tested as explanations for the presence of damage by kākā on residents' properties, only four contributed to the confidence model set $(\Sigma \omega>0.95$, Table 3.2). The leading model: Feeder + kākā freq + SiteID, carried almost half of the Akaike weights (i.e. $\omega$ $=0.46$; Table 3.2). Kākā visit frequency was the leading predictor for the presence of damage $\left(\sum \omega=1.0\right)$. The second model that included the interaction of visiting frequency and group size was also substantially supported $(\triangle \mathrm{AICc}=1.42, \omega=0.227)$, although it is a much larger model than the first. All other fixed- and random effects were present in poorer performing models or were unweighted (Table 3.2). Models describing the presence, nearness and number of people feeding kākā were implausible (i.e., $\Delta$ AICc >10, Table 3.2). The "Feeder" and random-effect (SiteID) variables by themselves, scored poorly $(\triangle \mathrm{AICc}=78.95$ and 79.18, respectively; Table 3.2). The reporting of damage presence, therefore, does not appear to be influenced by the respondent already having a relationship with kākā because they feed 
them. Reported damaged also does not vary in a systematic way between neighbourhoods and surveyed sites. 
Table 3.2: The candidate set of 22 linear mixed-effect models as hypotheses for the drivers of the presence of kākā damage reported by Wellington City residents on their properties. Models are displayed in descending order of likelihood, ranked by second order Akaike's Information Criterion score ( $\triangle \mathrm{AICc})$ and Akaike weights $(\omega)$. The number of parameters in each model are also shown $(K)$. The number of respondents in the sample $(n)$ is 611 . Models with $\triangle$ AICc scores $<2$ have substantial support. Scores of $<10$ indicate plausible models and $>10$ are implausible models.

\begin{tabular}{|c|c|c|c|c|}
\hline Model & $\boldsymbol{K}$ & AICc & $\triangle \mathrm{AICc}$ & $\boldsymbol{\omega}$ \\
\hline Feeder + kākā freq + SitelD & 4 & 412.89 & 0.00 & 0.461 \\
\hline Feeder + kākā freq + group size + distKWS + (kākā freq * group size) + SiteID & 7 & 414.31 & 1.42 & 0.227 \\
\hline Feeder + kākā freq + group size + SitelD & 5 & 414.42 & 1.53 & 0.21 \\
\hline Feeder + kākā freq + group size + distKWS + SiteID & 6 & 416.46 & 3.57 & 0.078 \\
\hline Feeder + kākā freq + group size + distKWS + (kākā freq * group size * distKWS) + SiteID & 10 & 419.28 & 6.39 & 0.019 \\
\hline Feeder + group size + Site ID & 4 & 460.37 & 47.48 & 0.000 \\
\hline Feeder + feeding freq + feeder prox + site feeders + distKWS $+($ feeder prox $*$ site feeders $*$ feeding freq $*$ distKWS + SitelD & 14 & 479.08 & 66.19 & 0.000 \\
\hline Feeder + feeding freq + feeder prox + site feeders + SitelD & 6 & 482.91 & 70.02 & 0.000 \\
\hline Feeder + feeding freq + feeder prox + site feeders $+($ feeder prox $*$ feeding freq $)+$ SiteID & 6 & 482.91 & 70.02 & 0.000 \\
\hline Feeder + feeding freq + feeder prox + site feeders $+($ feeder prox $*$ feeding freq $*$ site feeders $)+$ SitelD & 8 & 484.34 & 71.44 & 0.000 \\
\hline Feeder + feeding freq + feeder prox + site feeders + distKWS + SitelD & 7 & 484.55 & 71.66 & 0.000 \\
\hline Feeder + feeding freq + feeder prox + site feeders + distKWS $+($ feeder prox $*$ feeding freq $)+$ SitelD & 7 & 484.55 & 71.66 & 0.000 \\
\hline Feeder + feeding freq + feeder prox + site feeders $+($ feeder prox $*$ site feeders $)+$ SitelD & 7 & 484.96 & 72.07 & 0.000 \\
\hline Feeder + feeding freq + feeder prox + site feeders + distKWS $+($ feeder prox $*$ site feeders $*$ feeding freq $)+$ SitelD & 9 & 485.94 & 73.05 & 0.000 \\
\hline Feeder + feeding freq + feeder prox + site feeders + distKWS + (feeder prox $*$ site feeders $)+$ SitelD & 8 & 486.60 & 73.71 & 0.000 \\
\hline Feeder + feeder prox + SitelD & 4 & 490.82 & 77.93 & 0.000 \\
\hline Feeder + feeding freq + feeder prox + SitelD & 5 & 491.20 & 78.31 & 0.000 \\
\hline Feeder + SitelD & 3 & 491.84 & 78.95 & 0.000 \\
\hline SitelD & 2 & 492.07 & 79.18 & 0.000 \\
\hline Feeder + feeder prox + distKWS + SitelD & 5 & 492.45 & 79.56 & 0.000 \\
\hline Feeder + feeding freq + feeder prox + distKWS +SiteID & 6 & 492.84 & 79.95 & 0.000 \\
\hline Feeder + distKWS + SitelD & 4 & 493.64 & 80.75 & 0.000 \\
\hline
\end{tabular}


Of the 22 candidate models tested as explanations for the extent of property damage by kākā, only two were required to achieve a confidence model-set (i.e., $\left.\sum \omega>0.95\right)$. The leading model: Feeder + kākā freq + group size + distKWS + (kākā freq * group size $)+$ SiteID, carried the majority of Akaike weights (i.e., $\omega=0.883$; Table 3.3) followed by the simpler model including only kākā freq (i.e., $\omega=0.086)$. Kākā visit frequency was the leading predictor of reported damage $\left(\sum \omega=1.0\right)$ followed by kākā group size $\left(\sum \omega=0.91\right)$. The interaction between kākā visit frequency and group size contributes to the leading model's explanatory power (Figure 3.1). Larger groups of kākā appear to be associated with greater amounts of reported damage only when kākā visit a property frequently. All other fixed- and random-effects are presented in substantially poorer performing (i.e., $\Delta \mathrm{AICc}>2$ ) or implausible (i.e., $\triangle \mathrm{AICc}>10$ ) models (Table 3.3). Models describing the presence, nearness and number of people feeding kākā were implausible and unweighted (Table 3.3). Lastly, both the "Feeder" and the random-effect (SiteID) variables were poor models and predictors $(\triangle \mathrm{AICc}=53.97$ and 53.52.1, respectively). The reporting of damage, therefore, does not appear to be influenced by the status of the respondent as already having a relationship with kākā because they feed them and does not vary in a systematic way between neighbourhoods and surveyed sites. 
Table 3.3: The candidate set of 22 linear mixed-effect models as hypotheses for the drivers of total kākā damage reported by Wellington City residents on their properties. Models are displayed in descending order of likelihood, ranked by second order Akaike's Information Criterion score $(\triangle \mathrm{AICc})$ and Akaike weights $(\omega)$. The number of parameters in each model are also shown $(K)$. The number of respondents in the sample $(n)$ is 611 . Models with $\triangle \mathrm{AICc}$ scores $<2$ have substantial support. Scores of $<10$ indicate plausible models and $>10$ are implausible models (Burnham and Anderson, 2004).

\begin{tabular}{|c|c|c|c|c|}
\hline Model & $\boldsymbol{K}$ & $\mathrm{AlCc}$ & $\triangle \mathrm{AICc}$ & $\boldsymbol{\omega}$ \\
\hline Feeder + kākā freq + group size + distKWS + (kākā freq * group size) + SiteID & 8 & 2300.06 & 0.00 & 0.883 \\
\hline Feeder + kākā freq + SitelD & 5 & 2304.59 & 4.53 & 0.092 \\
\hline Feeder + kākā freq + group size + distKWS + SitelD & 7 & 2308.91 & 8.85 & 0.011 \\
\hline Feeder + kākā freq + group size + SitelD & 6 & 2309.24 & 9.18 & 0.009 \\
\hline Feeder + kākā freq + group size + distKWS + (kākā freq * group size * distKWS) + SiteID & 11 & 2310.25 & 10.19 & 0.005 \\
\hline Feeder + feeder prox + feeding freq + site feeders $+($ feeder prox $*$ feeders per site $)+$ SitelD & 8 & 2321.78 & 21.72 & 0.000 \\
\hline Feeder + feeder prox + feeding freq + site feeders + SiteID & 7 & 2323.94 & 23.88 & 0.000 \\
\hline Feeder + feeder prox + feeding freq + site feeders $+($ feeder prox $*$ feeding freq $)+$ SiteID & 7 & 2323.94 & 23.88 & 0.000 \\
\hline Feeder + feeder prox + feeding freq + site feeders + distKWS $+($ feeder prox $*$ site feeders $)+$ SitelD & 9 & 2324.17 & 24.11 & 0.000 \\
\hline Feeder + feeder prox + feeding freq + site feeders $+($ feeder proximity $*$ feeding freq $*$ site feeders $)+$ SitelD & 9 & 2324.25 & 24.19 & 0.000 \\
\hline Feeder + feeder prox + feeding freq + distKWS + SiteID & 7 & 2325.70 & 25.64 & 0.000 \\
\hline Feeder + feeder prox + feeding freq + site feeders + distKWS + SiteID & 8 & 2325.82 & 25.76 & 0.000 \\
\hline Feeder + feeder prox + feeding freq + site feeders + distKWS $+($ feeder prox $*$ feeding freq $)+$ SitelD & 8 & 2325.82 & 25.76 & 0.000 \\
\hline Feeder + feeder prox + feeding freq + site feeders + distKWS $+($ feeder prox $*$ feeding freq $*$ site feeders $)+$ SiteID & 10 & 2326.60 & 26.53 & 0.000 \\
\hline Feeder + feeder prox + feeding freq + SitelD & 6 & 2327.42 & 27.36 & 0.000 \\
\hline Feeder + group size + SitelD & 5 & 2327.58 & 27.52 & 0.000 \\
\hline Feeder + feeder prox + feeding freq + site feeders + distKWS $+($ feeder prox $*$ feeding freq $*$ site feeders $*$ distKWS + SiteID & 15 & 2334.99 & 34.93 & 0.000 \\
\hline Feeder + feeder prox + distKWS + SiteID & 6 & 2339.08.94 & 39.02 & 0.000 \\
\hline Feeder + feeder prox + SitelD & 5 & 2341.02 & 40.96 & 0.000 \\
\hline Feeder + distKWS + SitelD & 5 & 2353.01 & 52.95 & 0.000 \\
\hline SitelD & 3 & 2353.58 & 53.52 & 0.000 \\
\hline Feeder + SitelD & 4 & 2354.03 & 53.97 & 0.000 \\
\hline
\end{tabular}




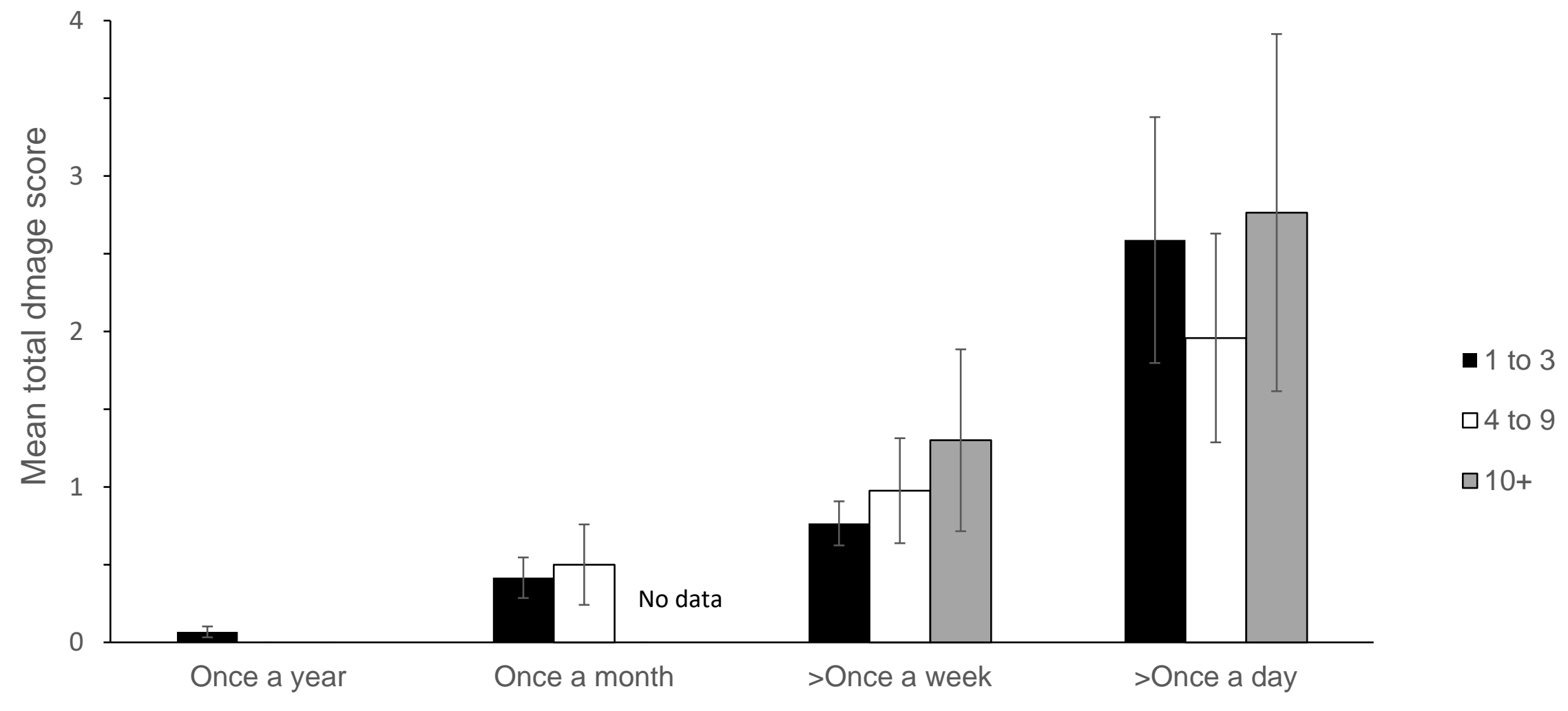

Kākā visiting frequency

Figure 3.1: Mean damage scores ( $\pm 1 \mathrm{SE})$ reported by residents in response to kākā visiting frequency and group size (black bar:1 to 3 kākā, white bar: 4 to 9, grey bar: 10+). Damage is scored from 4 sources; roofing, other building surfaces, trees, and miscellaneous other. Damage reported by residents increases as the frequency with which kākā visit properties increases. Damage from kākā also appears to be exacerbated when they congregate in greater numbers. This interaction is significant in explaining both damage presence and extent on residential properties $(\Delta \mathrm{AICc}=0.00, \omega=0.889$, Table 3.2; $\Delta \mathrm{AICc}=1.30, \omega=0.235$, Table 3.3 $)$. 


\subsubsection{Kākā damage and attitudes}

Models for resident attitude including all fixed-effects but different combinations of the two random-effects: Resident (respondent) and Site (neighbourhood); reveal that the randomeffect for Site did not contribute to explaining attitude and was not necessary for model selection and inference (Table 3.4). Therefore, answers to the seven attitudinal questions appear to be similar by individual residents but vary substantially among them. They do not, however, vary among neighbourhoods. Thus, only the random effect for residents was used in further analyses to test for the relationships between kākā, kākā damage and resident attitudes.

Table 3.4: The candidate set of 3 linear mixed-effect models as hypotheses for the suitability of random-effects, SiteID and ResID. Models are displayed in descending order of likelihood, ranked by second order Akaike's Information Criterion score ( $\triangle \mathrm{AICc})$ and Akaike weights $(\omega)$. The number of parameters in each model are also shown $(K)$. The number of respondents in the sample $(n)$ is 611 . Models with $\triangle \mathrm{AICc}$ scores $<2$ have substantial support. Scores of $<10$ indicate plausible models and $>10$ are implausible models (Burnham and Anderson, 2004).

\begin{tabular}{lcccc}
\hline Model & $\boldsymbol{K}$ & AICc & \multicolumn{1}{c}{$\Delta$ AICc } & $\boldsymbol{\omega}$ \\
\hline feeder + damage type + repair cost + total damage + (1|resID $)$ & 9 & 13075.47 & 0 & 0.731 \\
feeder + damage type + repair cost + total damage + (1| sitelD/resID) & 10 & 13077.47 & 2 & 0.269 \\
feeder + damage type + repair cost + total damage + (1| sitelD $)$ & 9 & 13395.37 & 319.9 & 0.000 \\
\hline
\end{tabular}

Residents answers to the seven attitude questions were not different if they answered them before (cf. after) questions about kākā abundance and damage $\left(F_{1,298}=0.007, P=0.93\right.$ :

Figure 3.2). Thus, the order of the questions did not influence residents reporting their attitudes. Reporting kākā and damage first did not lead residents to report more negative attitudes. In fact, the opposite, but not statistically significant, trend occurred (Figure 3.2). Although question order was not found to be statistically influential on answers to the attitude 
questions, it is possible that a person's existing relationship with kākā might interact with question order to influence their answers. For example, people feeding kākā may be less likely to be influenced by the order of questions because they have a high positive regard for kākā. Nonetheless, the interaction between question order in the survey and whether residents fed kākā was also not statistically significant $\left(F_{1,298}=0.330, P=0.57\right.$, Figure 3.3). The attitudes of those feeding kākā were not less (or more) modified by question order than other respondents.

There was, however, a significant difference in attitudes between residents that fed kākā and those that $\operatorname{did} \operatorname{not}\left(F_{1,611}=7.415, P=0.007\right.$, Figure 3.3). Feeders showed more positive attitudes towards kākā overall $(U=8652.5, P=0.013)$. Mann Whitney $U$ tests showed significant differences in attitudes between residents that fed kākā and those that did not, for the third $(U=9291.5, P=0.012)$ and sixth $(U=9162, P=0.03)$ attitude questions, which regard their enjoyment of kākā and the managing of kākā if they cause problems (Figure 3.4).

While statements four and seven were not statistically significant at the 0.05 level, they followed the trend ( $U=9615, P=0.06$ and $U=9637, P=0.08$ respectively). 


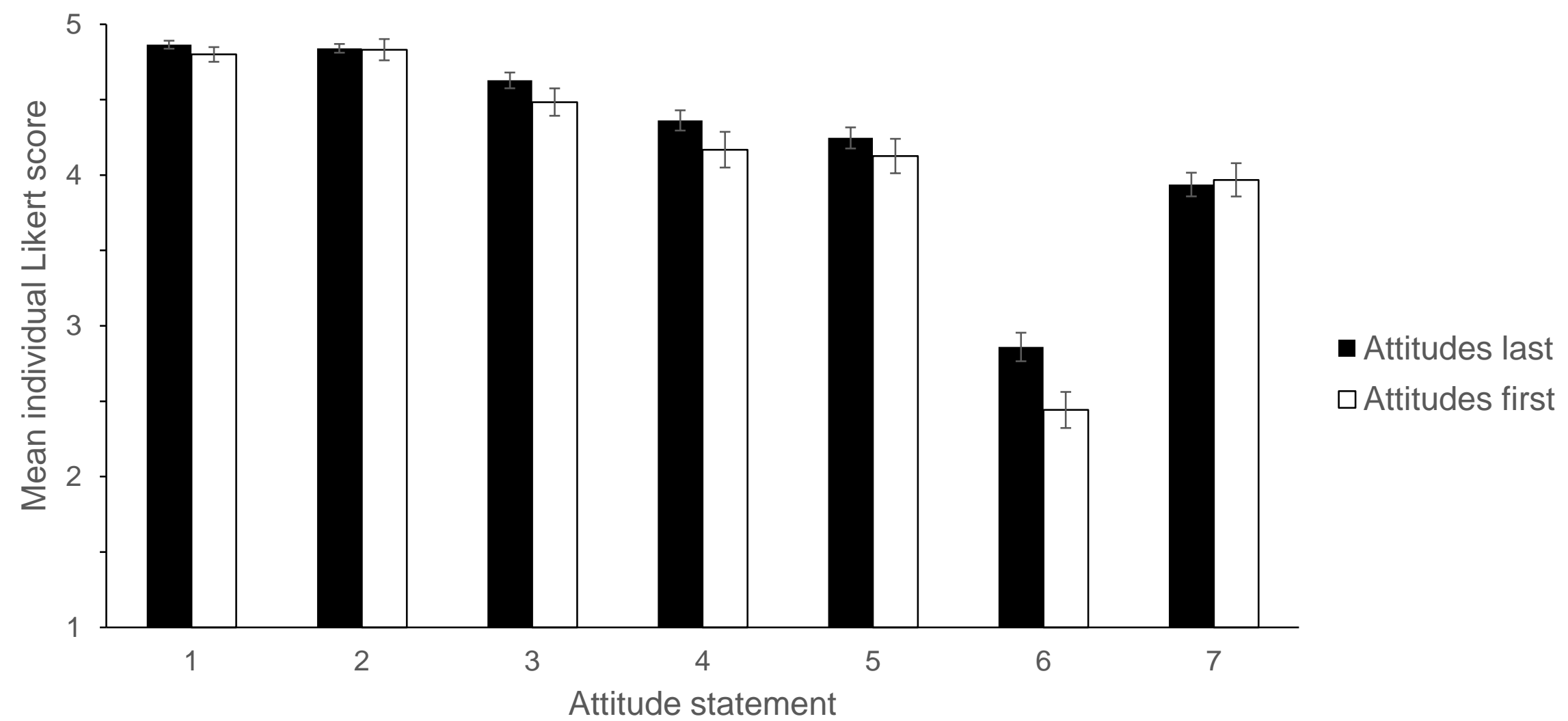

Figure 3.2: Mean Likert scores $( \pm 1 \mathrm{SE})$ to the seven attitude statements from the surveys in which responses to attitude statements occurred before or after questions about kākā abundance and damage to resident's property. The attitude statements were: (1) Native birds are an asset to our city, (2) Native wildlife deserves to be protected, (3) You enjoy seeing kākā in your neighbourhood, (4) Kākā have a right to live in our city, (5) You want to see more kākā in your neighbourhood, (6) Kākā should be managed if they cause problems, (7) People should tolerate kākā regardless of the problems caused. Answering questions about kākā abundance and damage before responding to attitude statements did not result in lower scores for attitude $\left(F_{1,298}=0.007, P=0.93\right)$ 


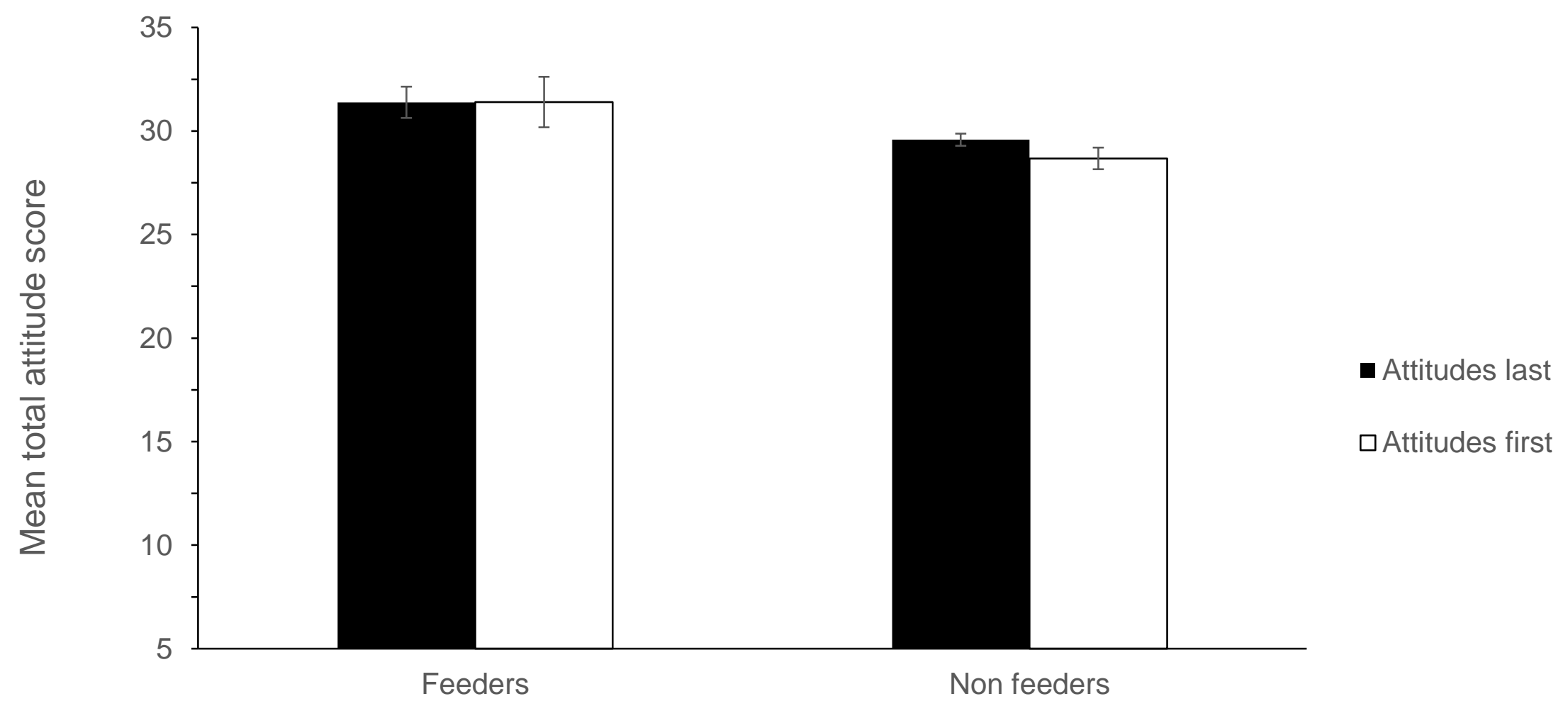

\section{Feeding status}

Figure 3.3: Mean sum of Likert scores $( \pm 1 \mathrm{SE})$ from seven attitude statements by respondents who report feeding or not feeding kākā given the order of attitude and kākā abundance and damage questions in the survey they answered. Responses to attitude statements were not explained by an interaction between respondent feeding behaviour and the order of attitude and kākā abundance and damage questions $\left(F_{1,298}=0.330, P=\right.$ 0.57). 


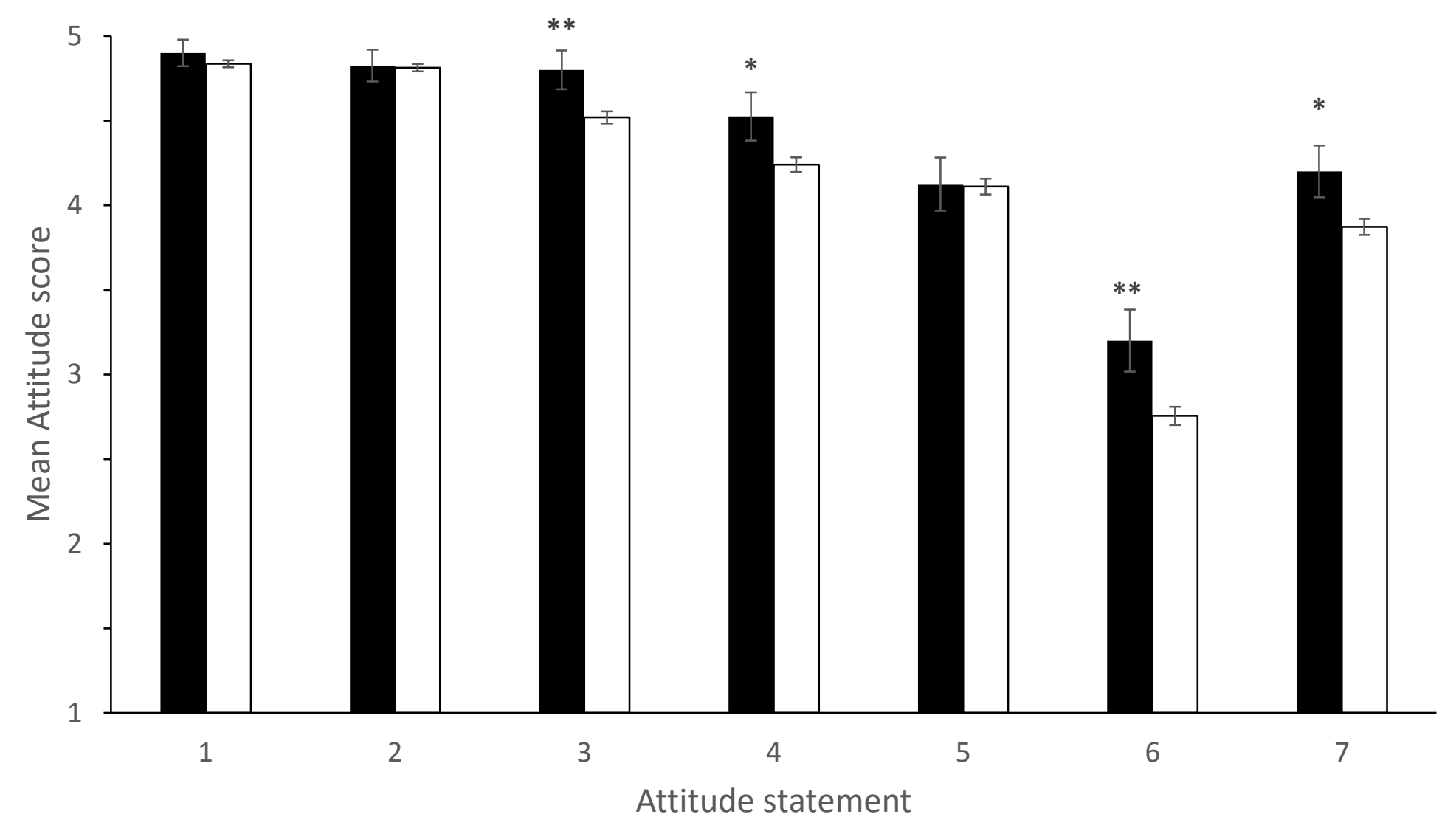

- Feeders

$\square$ Non feeders

Figure 3.4: Mean Likert scores ( \pm 1SE, possible range 1 to 5 ) to the seven attitude statements from the surveys which compared responses from feeders to those of non-feeders. The attitude statements were: (1) Native birds are an asset to our city, (2) Native wildlife deserves to be protected, (3) You enjoy seeing kākā in your neighbourhood, (4) Kākā have a right to live in our city, (5) You want to see more kākā in your neighbourhood, (6) Kākā should be managed if they cause problems, (7) People should tolerate kākā regardless of the problems caused. Overall, feeders had more positive attitude responses than non-feeders $\left(\mathrm{F}_{1,611}=7.415, \mathrm{P}=0.007\right)$. More specifically, attitudes differed on statements three, four, six and seven. There was no significant difference between statements one, two and five. ' $*$ ' indicates $\mathrm{P}<0.1$, ' $* *$ ' indicates $\mathrm{P}<0.05$. 
Overall damage reported on properties did not significantly impact mean attitude scores $\left(F_{1,611}=0.328, P=0.567\right)$ and attitude scores did not significantly differ with the part of residents' property that had been damaged $\left(F_{3,611}=1.900, P=0.130\right)$. However, the financial cost of repairs that some residents carried out were significantly linked to more negative responses to attitude statements $\left(F_{1,611}=7.495, P=0.006\right)$. Residents that spent up to $\$ 50$ in repair costs did not have significantly different total attitudes scores $(29.7 \pm 1.9)$ to those that had damage but did not repair it $(28.8 \pm 0.6 ; U=238, P=0.615)$. However, when the cost involved was greater than $\$ 50$, overall attitude scores were significantly lower $(21.9 \pm 2.1 ; U$ $=53, P=0.026 ;$ Figure 3.5)

The cost to repair damage also impacted answers to individual attitude tests. Kruskal Wallace tests found statistically significant differences in statements one $(H(3)=14.81, P=$ $0.002)$, four $(H(3)=20.74, P=0.0001)$ and five $(H(3)=29.58, P=<0.0001)$. These statements regard attitude to native birds as assets to the city, kākā having a right to live in the city, and wanting to see more kākā in their neighbourhood. Attitudes from those who had a cost of $\$ 1-\$ 50$ did not differ significantly from the two groups who had no repair cost, across all seven statements (Figure 3.6).

The interaction between whether a resident fed kākā or not and the cost to repair damage did not lead to significant differences in mean attitude scores $\left(F_{1,611}=0.529, P=0.467\right)$. Similarly, the interaction between feeding and overall property damage also was not associated with significantly different mean attitude scores $\left(F_{1,611}=0.190, P=0.663\right)$.

The leading predictors for the cause of damage (including kākā visit frequency and group size, see Table 3.3) were substantially poorer explanations of residents attitudes than predictors that described damage and the costs of repair (Table 3.5), indicating that kākā damage, rather than kākā themselves, are the 'attitude object' for residents. 
Table 3.5: The candidate set of three linear mixed-effect models for testing whether factors driving damage better explained attitudes than aspects of damage itself. Models are displayed in descending order of likelihood, ranked by second order Akaike's Information Criterion score $(\triangle \mathrm{AICc})$ and Akaike weights $(\omega)$. The number of parameters in each model are also shown $(K)$. The number of respondents in the sample $(n)$ is 611 . Models with $\triangle$ AICc scores $<2$ have substantial support. Scores of $<10$ indicate plausible models and $>10$ are implausible models (Burnham and Anderson, 2004).

\begin{tabular}{|c|c|c|c|c|}
\hline Models & k & AICc & $\triangle \mathrm{AICc}$ & $\omega$ \\
\hline Feeder + damage type + repair cost + damage $+(1 \mid$ res. ID $)$ & 7 & 13017.8 & 0 & 0.997 \\
\hline Feeder + freq. $+(1 \mid$ res.ID $)$ & 5 & 13030.5 & 12.74 & 0.002 \\
\hline Feeder + freq. + group size + distKWS + (freq. ${ }^{*}$ group size $)+(1 \mid$ res.ID) & 8 & 13031.1 & 13.29 & 0.001 \\
\hline
\end{tabular}




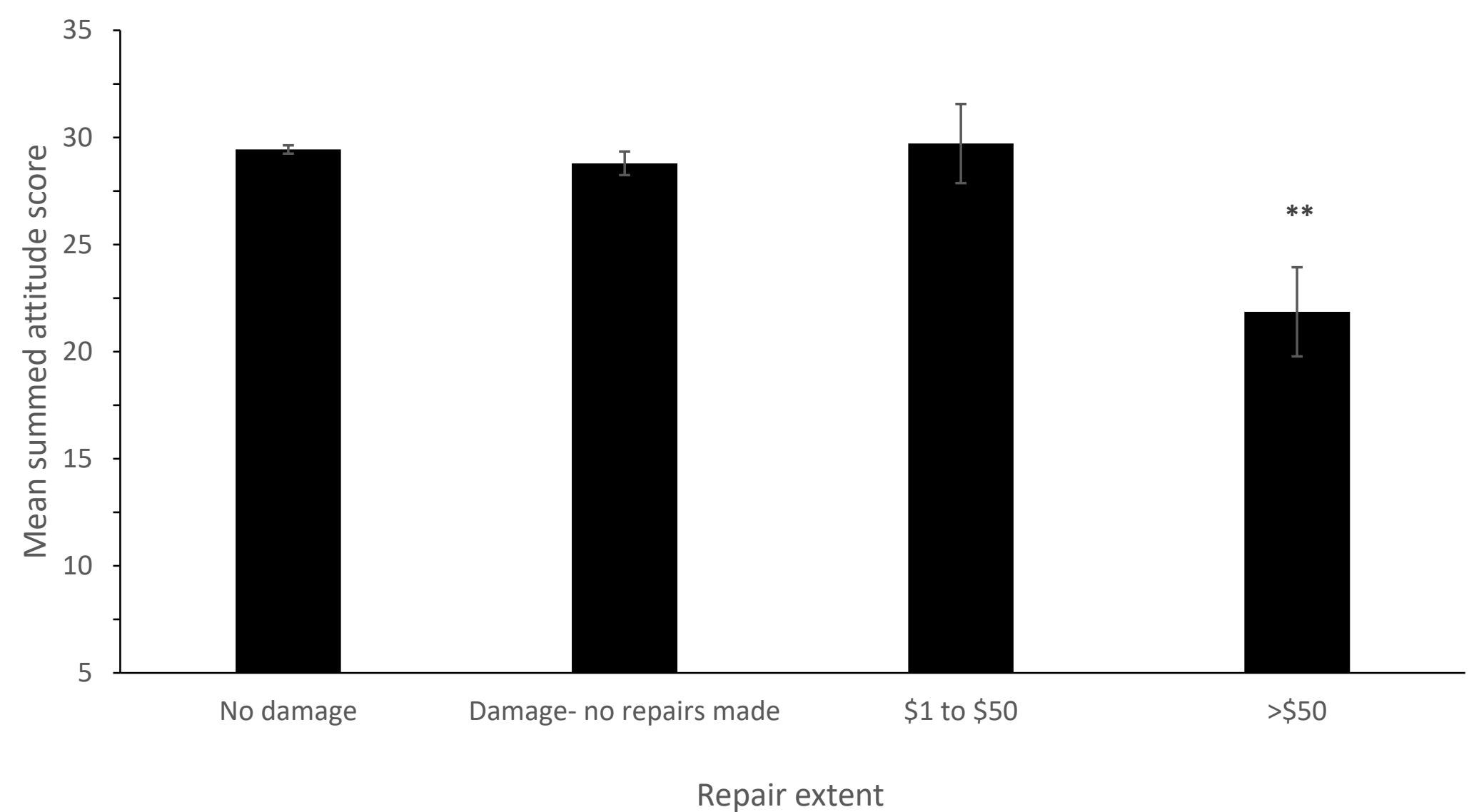

Figure 3.5: Mean summed attitude scores $( \pm 1 \mathrm{SE})$ from residents who spent varying degrees of financial cost to repair damage to their property by kākā. Residents who spent upwards of $\$ 50$ showed more negative attitudes overall than those who had damage but chose not to repair damage and those who spent $\$ 1-\$ 50\left(F_{1,611}=7.495, P=0.006\right)$. '**' indicates $P<0.05$. 


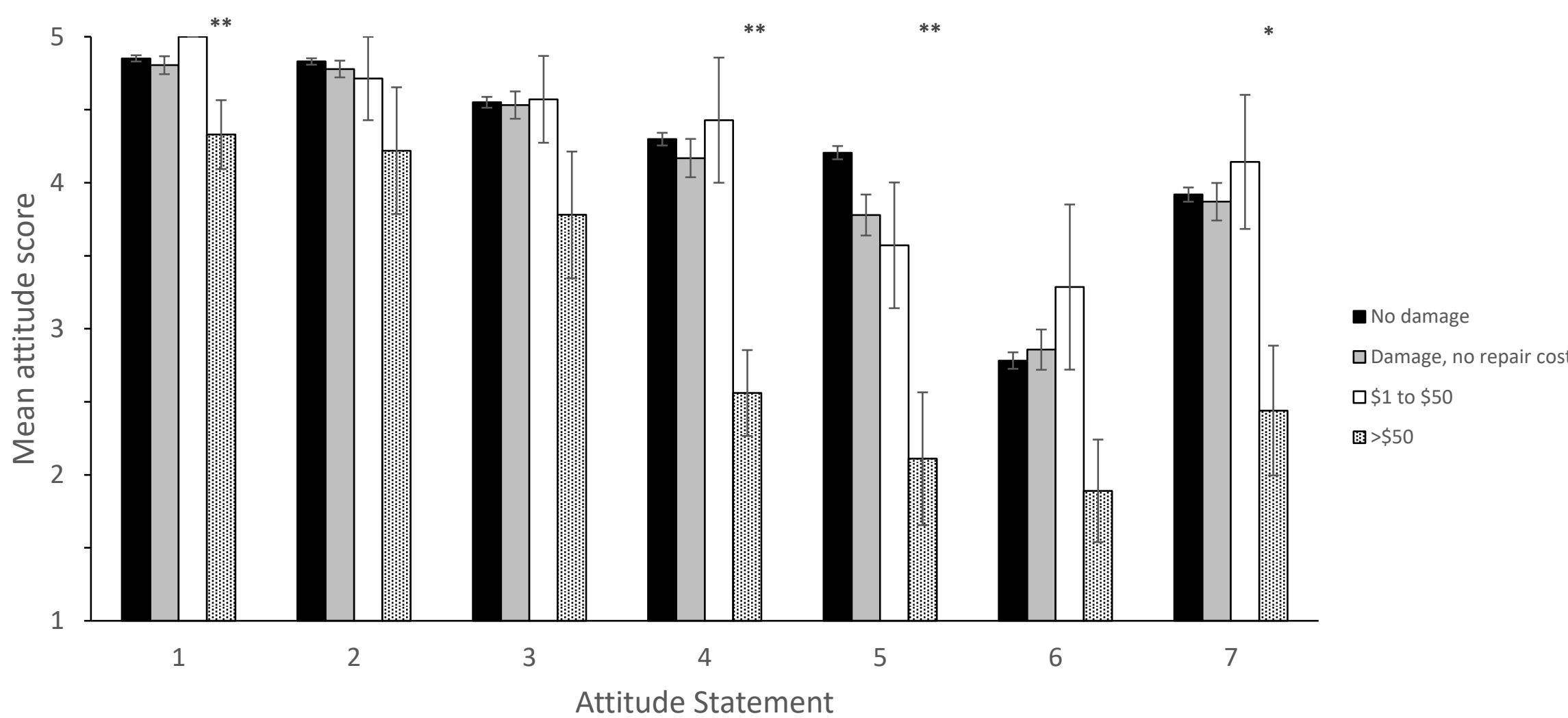

Figure 3.6: Mean Likert scores ( $\pm 1 \mathrm{SE}$, possible range 1 to 5 ) to the seven attitude statements from the surveys which compared responses from residents who spent varying degrees of financial cost to repair damage. The attitude statements were: (1) Native birds are an asset to our city, (2) Native wildlife deserves to be protected, (3) You enjoy seeing kākā in your neighbourhood, (4) Kākā have a right to live in our city, (5) You want to see more kākā in your neighbourhood, (6) Kākā should be managed if they cause problems, (7) People should tolerate kākā regardless of the problems caused. While the attitudes of those that spent more than $\$ 50$ were lower than other groups across all questions, these differences were exaggerated in questions four to seven. '*' indicates $P<0.1$, '**' indicates $P<0.05$. 


\subsection{Discussion}

The attitudes of Wellington City residents to native avian wildlife and kākā, the reintroduced parrot specifically, are being influenced by their experience of property damage which they attribute to kākā. The more kākā are observed on a property by residents the more likely damage is also reported. The residents who report costly property damage by kākā also report more negative attitudes to native birds and particularly kākā. However, residents' attitudes appear robust to minor damage, even that requiring repairs, so long as the estimated cost of those repairs is small. Thus, my survey reveals a human-wildlife conflict driven by the cost of repairing damage, where damage, not the animal, is the object influencing attitude (i.e., the attitude object). However, minor damage and repair costs are widely tolerated by residents. Whether the reintroduction of kākā leads to a growing human-wildlife conflict, therefore, appears to depend on whether damage by kākā intensifies to impose greater costs on more residents.

\subsubsection{Kākā damage}

Residential reports of damage to property by kākā and the amounts of damage reported were best explained by how frequently residents observed kākā visiting their properties. The largest number of kākā reported to visit residents' properties at the same time was not, on its own, a strong predictor of damage. However, the largest kākā group sizes (i.e., 10 or more) visiting residents' properties were associated with considerably more damage when kākā visited 'more than once a day', and less damage when they visited less frequently. Thus, the number of kākā visiting a property at the same time appears to reduce or exacerbate damage, depending on how frequently the property is visited by kākā (Figure 3.1). 
All kākā, whether they are alone or in a group, have the capacity to damage property during their normal foraging and exploring activity. However, as kākā are social parrots, they also congregate in groups for social activities such as play (Diamond and Bond, 2004), rather than for foraging. There are also locations that kākā prefer to visit more frequently, specifically for foraging behaviour. When these locations are visited frequently and in large numbers, damage extent can be exacerbated. Of the 19 cases in which kākā were reported to visit more than once a day and in group sizes of 10 or more, eight (52\%) reported no damage. While social play of kākā in groups has been documented (Diamond et al, 2006), there is little known empirically about the damaging behaviour of kākā in flocks. Further studies on kākā group behaviour outside of social play may be beneficial in further understanding instances of damage.

Contrary to my hypothesis, predictors that described anthropogenic feeding of kākā by residents did not best explain the presence nor amount of reported kākā damage to residents' properties. Variables such as whether a resident fed kākā, how often they fed, whether residents were a neighbour to a feeder and how many feeders there were in each neighbourhood all performed substantially worse than the models including kākā visit frequency and group size as predictors. This finding appears, initially, to be counterintuitive because, in my previous chapter, I found the number of feeders at a site to be a useful predictor of kākā presence around Wellington City.

My hypothesis regarding residential feeding and damage was based on residential feeders increasing the density of kākā in the vicinity, and as a result, increasing the natural damage they do through foraging behaviour, sap feeding and possibly, possible beak maintenance. To an extent, there may be enough evidence to accept this hypothesis. The previous chapter found that the number of residential feeders per site was a strong driver in increasing the kākā abundance on a property, while this chapter indicates that increased 
abundance, particularly increased visiting frequency, leads to increased property damage. Therefore, it would also be expected that feeding variables such as feeders per site and the proximity to a feeder would be stronger predictors for damage. However, while kākā do damage property proximal to feeders, they can also damage property at other locations they visit, through their everyday foraging behaviour. Of the 93 reports of property damage, 33 cases were either at a feeder, or to the property of the neighbour of a feeder, while the other 60 reports were not proximal to feeders. The previous chapter showed increased kākā presence at sites with more feeders, however, kākā are proficient fliers and are not restricted to these locations (Moorhouse et al. 2003).

One similar documented case of feeding leading to property damage is in urban Australia, where the Sulphur-crested Cockatoo (Cacatua galerita) have been observed frequenting residences which participate in bird feeding. Cockatoos, like most other parrots, also have a continuously growing beak which is maintained by chewing. At these feeding properties, cockatoos have been observed damaging softer wood on buildings, particularly wall cladding, windowsills and doorframes as a consequence of beak maintenance behaviour (Temby, 2004). This beak maintenance behaviour may also extend to and explain kākā damaging building surfaces. Damage to trees is generally a result of sap feeding and foraging for wood boring insects. However, the damaging of houses offers no nutritional benefits to kākā, and therefore must be explained by another mechanism. It can possibly be explained as an inbuilt, reactionary behaviour by kākā to maintain their beak condition, regardless whether the surface is natural, or man-made.

There was also no significant relationship between kākā damage and the distance of the site to Karori Wildlife Sanctuary. This is not surprising as kākā are proficient dispersers and have been reported up to $4000 \mathrm{~m}$ away in this study. Kākā visiting sites across varying distances from the sanctuary can all damage property through their natural behaviours. As 
abundance is a strong predictor for property damage, this is further reinforced by the previous chapter's findings, which showed that the distance from the KWS to a study site was not a strong predictor of kākā visiting frequency and group size.

\subsubsection{Attitudes to $k \bar{a} k \bar{a}$}

Greater reported damage by kākā was associated with more negative attitudes to native birds and particularly kākā, but only when it imposed a substantial cost on residents. Residents were tolerant of damage, even that requiring repairs, so long as their estimated cost of those repairs was $\$ 50$ or less. There was a wide range of costs involved in repairing or acting on property damage; from a minimum of $\$ 8$ for nets to place over apple trees, to some residents required to spend $\$ 6000$ to replace exterior cladding on housing. Residents that spent minor amounts repairing damage had similar attitudes to those that had damage but chose not to repair, and more significantly, residents who had no damage on their property at all (Figure 3.5; Figure 3.6). This tolerance towards the negative impacts of kākā is encouraging for the ongoing relationship between kākā and Wellington residents. However, the residents who spent more than $\$ 50$ showed significant declines in total attitudes. Despite there only being significant differences across attitude statements one, four and five, there is a general decline in attitude across all seven statements (Figure 3.6). The lower response to statement one suggests that spending financial resources to repair property damage can negatively influence an individual's attitudes towards other native birds in the city. While the responses to statement one is still generally positive and statement two (regarding the protection of native wildlife) is not significantly lower, the possibility that prolonged issues of repairing damage further deteriorating attitudes should not be discounted. The responses by those spending $>\$ 50$ to statements four and five regarding 'Kākā have a right to live in the city' and 'You want to see more kākā in your neighbourhood' respectively, were significantly lower than 
other groups. The lower attitudes to these two statements are not surprising. They hold insight into residents' tolerance for kākā and suggest that there are circumstances in which kākā can reach the social carrying capacity of Wellington City. As the kākā population in the city grows, it can be expected that instances of property damage and repairing property damage will become more common. Should the belief that kākā do not have a right to live in the city become widespread due to cases of moderate to large financial expenditure, conservation managers within the city will be under pressure to manage the population (Statement six). While statement six was not significantly lower than other groups, it still displays a trend which may worsen if the conflict grows. A growing kākā population also opposes attitudes in statement five, which describes the limit of the physical kākā presence that residents find tolerable.

It was also expected that residents in urban environments would place more value on their housing than on the trees present on their property. Therefore, they would respond in a more negative manner should damage occur on building surfaces. However, where the damage occurred on the property also did not significantly affect attitude scores. With the finding that increased financial expenditure that affects attitudes, this is understandable as the financial cost of removing dead trees is large. Residents removing dead trees due to kākā damage spending over $\$ 650$ each, with one resident spending upwards of $\$ 3000$.

While overall attitudes did not change significantly as reported damage increased, higher damage reports should not be without concern. Should damage continue to accumulate on properties, repairing damage may be inevitable. While only being a portion of the overall conflict solution, finding a way of minimising the impact kākā have on people is still a crucial step. As repair costs appear to be the driving factor in attitudes towards kākāa financial compensation from governmental or city council bodies for damage due to kākā is one possibility. Financial compensation for wildlife damages is a common means of mitigating 
impacts to people, both urban and rural, and resolving the conflict (Wagner et al, 1997; Nyhus et al, 2005; Bauer et al, 2017). While common, it is not without its difficulties. It can be difficult to assess and quantify damage caused by the wildlife (Nyhus et al, 2005). Kākā damage to trees is distinctive, with lateral and transverse bark gouges that cannot be replicated by another species in Wellington City. Therefore, tree damage maybe be simple to assess, and if mortality occurs, tree removal can be easily compensated. However, damage to housing surfaces may not be as simple to assess nor compensate for. This can be due to the varying degrees of damage, repair methods, compensation extent and whether the damage was in fact, caused by kākā. The difficulty in assessing this damage may open new avenues for conflict to arise if governmental or city council bodies and residents cannot come to a satisfactory conclusion that suits both parties.

Financial compensation for damage may offset the financial impact that kākā have on residents, as they do not need to spend their own resources. However, some aspects of property may have additional sentimental value to a resident and therefore its true value is not easily encapsulated by financial means alone. While financial compensation schemes can alleviate extensive financial costs, it is limited in its ability to place value on property which may be priceless to a resident. In these cases, it is unlikely that compensation will help mitigate conflict.

As predicted, those residents that fed kākā responded more positively to the given attitude statements than those that did not. However, there are variations in how feeders and non-feeders responded across the statements (Figure 3.4). While overall there was an attitude difference between feeders and non-feeders, the two groups responded similarly to statements one, two and five. Statements one and two involved attitudes to wildlife more generally, while statement five regarded whether residents wanted to see more kākā in their neighbourhood. The similarities in responses to statements one and two shows that residents 
that do not feed kākā do not necessarily have a lesser appreciation of avifauna and conservation in general, compared to those that do feed. This is encouraging, as it indicates that while feeding may generally enhance a residents' appreciation for nature, it is not a requirement in Wellington. General appreciation for wildlife and conservation is unlikely to decrease if residents are encouraged to limit or stop feeding kākā.

Residents that fed kākā, however, did show a higher tolerance towards kākā and their presence specifically in Wellington City than those who did not feed, as indicated by the attitude differences in statements three and six. While only statements three and six regarding kākā were statistically significant, statements four and seven showed the same trend of more positive attitude towards kākā by feeders.

The extent of the damage and aspects of damage (repair cost and location) on properties were a significantly better explanation for attitude change than the cause of the damage, kākā presence. This shows that people are generally tolerant of kākā presence on their properties, until the damage that occurs on their property needs significant financial expenditure to repair or prevent.

\subsubsection{Limitations}

Due to the presence of subjectivity in self report surveys, it is possible that the order in which residents answered questions in the survey could subconsciously lead to some degree of bias. This may be particularly evident if the questions regarding the impact kākā have on properties (presence and damage) illicit strong emotions from residents at the time of filling out the survey. Furthermore, if residents have preconceived attitudes towards kākā, responding to attitude statements first may influence their responses to perceived property damage. This bias adds further subjectivity to answers in the survey and so testing for the presence of this influence is important to ensuring responses are as objective as possible. The 
methodological tests to detect this found no significant bias was present due to the survey question order. Answering questions regarding kākā presence and property damage prior to the attitude statements did not result in significantly different attitude scores compared to when asked afterwards. Furthermore, having an existing relationship with kākā through residential feeding also did not significantly change how residents perceived question order. The results of these tests allowed for more confidence in the responding data, as it eliminated the possibility of bias arising from question order.

By itself, the Feeder variable was unweighted, showing residents that feeding kākā did not significantly report lower damage compared to residents that did not. This is significant as self-reports in surveys, by nature, are open to some level of subjectivity. Therefore, residents that feed kākā may subconsciously report less damage than is present compared to a non-feeder, as they are more tolerant of it. 


\subsection{Conclusions and recommendations}

This chapter indicates that the driver in conflict with kākā and residents is the financial cost required to repair or prevent kākā damaging private property. The overall attitudes of the sample population are relatively positive and the residents that have spent over $\$ 50$ are few $(n=9)$. However, the attitudes of these residents to both general avifauna and kākā within the city provide insight into circumstances in which conflict could escalate if the kākā population grows without the necessary guidelines and precautions in place. The conflict should be closely monitored by government and council bodies. Means of mitigating this conflict should be explored, in case the kākā population and damage increases beyond the capacity of the community to tolerate them. 


\section{Chapter 4: General Discussion}

Since their introduction into Karori Wildlife Sanctuary in 2002, kākā have become a regular occurrence in Wellington City suburbs, both in public green spaces and on residential properties. Through their natural feeding and foraging behaviour, kākā have been observed to damage residential properties. This damage has been the predominant cause of a growing conflict involving kākā and the residents of Wellington City. This thesis explored the factors that influenced kākā presence on properties in the city, the factors that increased the presence and amount of damage by kākā to properties, and how this damage affected residents' attitudes towards kākā and avifauna in general.

\subsection{Summary}

The number of residents feeding kākā at a site was found to be the best predictor for explaining kākā abundance at a property. Kākā abundance increased as the number of feeders increased. Of note is the positive relationship between kākā abundance and the interaction between the number of feeders and a site's distance to KWS. The highest kākā abundance occurred on the two sites that were both closest to KWS and had the most feeders. However, outside of this interaction there was no relationship between distance from the sanctuary and kākā presence on properties. This finding is not entirely surprising, as it can be expected that properties immediately proximal to KWS (location with the highest concentration of kākā in the city) would experience the most frequent visitations, and the largest group sizes. However, it is surprising that there is no discernible pattern with distance outside of these two sites. This suggests that some kākā may have become independent from KWS as a refuge habitat and other factors are most likely driving their use of the landscape. Anthropogenic feeding appears to be a dominant influence. 
While not a great predictor of kākā presence by itself, urban density also appears to play a role in kākā presence on properties. Larger suburban lots are likely to have more space for vegetation to grow, particularly taller trees with larger crowns. These features are heavily represented in the plausible models, particularly predictors such as tree height, crown size, emergent trees and proximity to tracts of native vegetation.

Kākā presence was found to be the best explanatory variable for the presence and extent of damage on residential properties. Damage reports increased significantly as kākā visited properties more frequently. While kākā group size on its own was not a strong predictor of damage, the largest group sizes (10 or more) were also associated with increased damage when they visited 'more than once a day'. Feeding variables such as the number of feeders per site, whether a resident was a feeder or neighbour of one, or how often someone fed kākā were found to be substantially worse predictors than kākā presence.

While the extent of damage reported did not significantly affect residents' attitude, the presence of any damage on residential property presents the possibility that affected residents will have to repair it. There was a significant decrease in attitudes associated with greater financial costs required to repair damage. Residents tolerated minor financial costs with no significant decline in attitudes (cf. those with no damage or those that had damage but did not repair). When this cost increased upwards of $\$ 50$, overall attitudes were significantly more negative. While lower attitudes regarding kākā can be expected, these residents also showed significantly lower attitude scores towards other birdlife within the city. This is of concern as it signals a possible decline in support for birdlife in the city, as a result of the conflict. Should this conflict escalate and the number those financially affected increase, it may lead to an overall reduction in the social capacity of residents towards not only the problems caused by kākā but other avian problems too. 
Damage and the resulting costs were also found to be significantly stronger drivers of residents' attitude change than the presence of kākā on properties. This suggests that aspects related to damage, not kākā themselves, are the attitude modifiers in this interaction between people and kākā. Residents appear to either enjoy or tolerate kākā on their property until a point where property damage requires substantial financial costs to repair.

This conflict with kākā and Wellington residents is complex. It involves many facets such as residential feeding, kākā abundance and distribution, property damage, financial expenditure repairing damage and, ultimately, how resident's attitudes change in response to these variables (Figure 4.1). While residential feeding may not be directly responsible for the damage by kākā and the subsequent need to repair, it can be considered as an exacerbating factor in this chain of events. This ultimately can result in substantial financial impact on some residents and an escalation in the overall conflict.

\subsection{Limitations}

Empirical studies that attempt to quantify wildlife, environments and people's attitudes using self-report surveys must be interpreted carefully. The use of a self-report survey in this thesis was necessary as residents' own experiences with kākā were required. The answers from residents may be influenced by the residents' own motivations, experiences and how they interpret the survey questions. Residents who enjoy kākā may subconsciously report less damage than other residents. Similarly, residents who have had negative experiences with kākā may over-report damage and kākā presence. Much of these sources of inherent bias was recognised prior to the study, with steps taken in efforts to mitigate it. This was done through large sample sizes, deliberate study and survey design, and an ordinal regression analytical approach using generalised linear models with random effects for both study site and resident. 


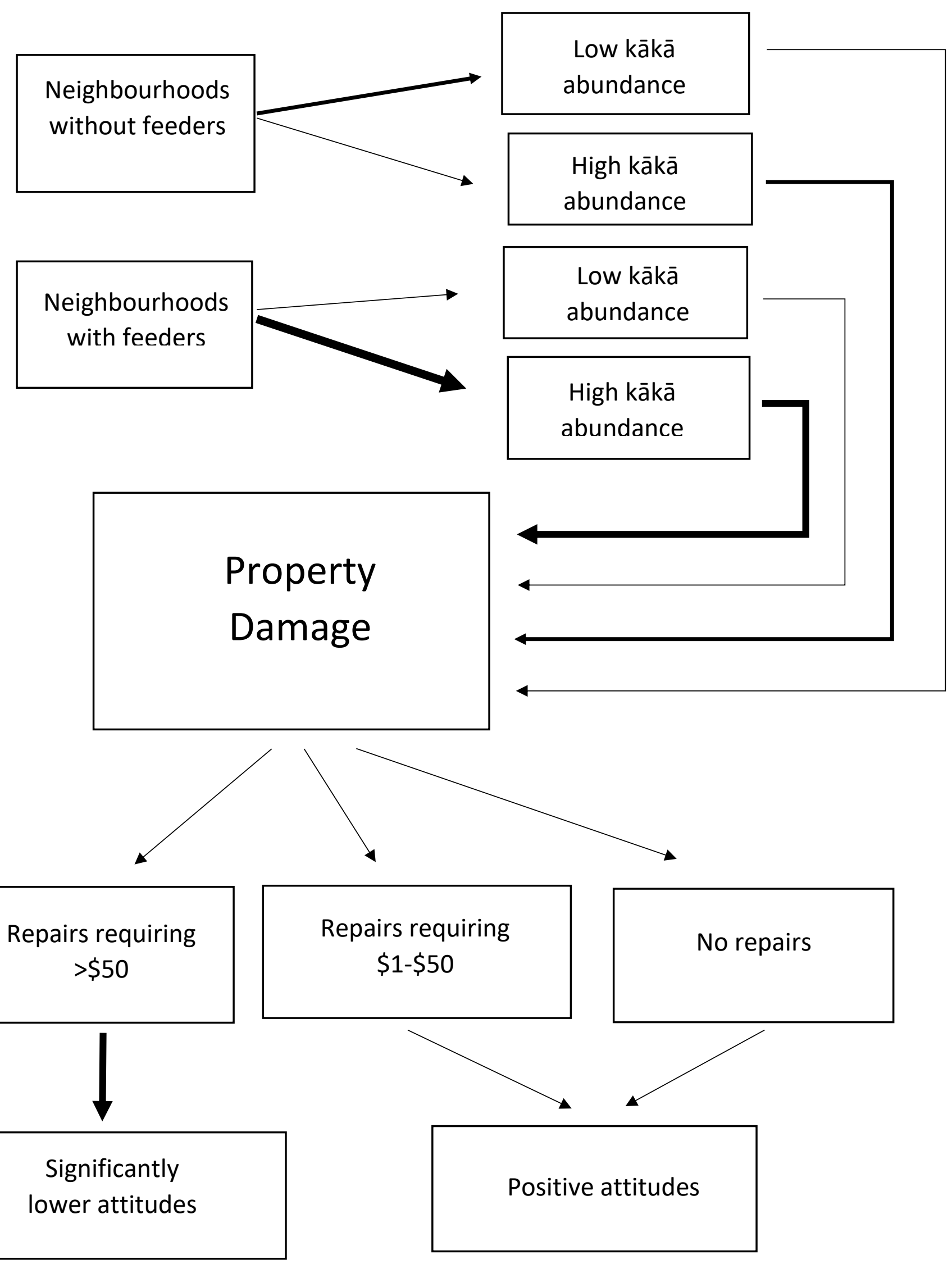

Figure 4.1: General pathway of kākā-resident interaction in Wellington City, from residential feeding and kākā abundance to resident attitudes. Darker arrows indicate a stronger relationship. 


\subsection{Recommendations}

While the overall residential attitudes of towards kākā are positive, there are circumstances in which conflict involving kākā and people can occur. If the kākā population in Wellington continues to grow, these occurrences are likely to become more common and increase in severity. To assist in managing this conflict, the following recommendations have been made based on findings in this thesis.

\subsubsection{Discouraging feeding}

As the main driver of kākā presence on properties, residential feeders appear to be influencing kākā distribution in Wellington. Their local abundance can lead to instances of increased property damage and in turn, the likelihood of this damage requiring repair. While high kākā abundance on properties not proximal to feeders can also lead to damage, discouraging residents from feeding kākā could help minimise the opportunities for these problems to arise. Furthermore, it is likely to also distribute kākā more evenly over the landscape, with their distribution influenced by other factors.

However, discouraging feeding by residents can prove challenging. Government and regional bodies such as the Department of Conservation (DoC) or the Wellington City Council (WCC) have limited control over what residents can or cannot do on their private properties, and so cannot enforce this. Furthermore, if feeders do not experience the consequences associated with feeding, it may be difficult for them to understand that their feeding may be artificially influencing kākā behaviour on a landscape level. Therefore, they may be less inclined to stop feeding when advised to. Bodies such as DoC or WCC can only discourage residents from feeding wildlife and attempt to educate them of the potential consequences involved with feeding. 
In general, discouraging feeding to avoid conflict may be paradoxical, as in many large cities wildlife feeding is one of the means with which people can engage with wildlife (Jones and Reynolds, 2007; Galbraith et al, 2014). Stopping or restricting wildlife feeding may inhibit many residents' direct engagement with nature, and over time, alter their attitudes towards it. However, this may not necessarily be the case in Wellington. Wellington City has numerous recreational green space areas such as the Karori Wildlife Sanctuary, OtariWilton's Bush and the Wellington Botanic Garden, among others. These spaces, along with larger regional parks proximal to the city, provide residents more opportunities to engage in environmentally related activities, than larger cities with fewer green spaces. This is reflected in the findings that non-feeding residents had similar, positive attitudes on general avifauna and conservation than residents who did feed kākā. This suggests that Wellington residents' overall appreciation for conservation and birdlife may be affected little, if at all, should feeding be stopped.

\subsubsection{Financial compensation}

Financial compensation schemes (FCS) have been used globally to help minimise the impact that wildlife has on people. Financial compensation has been used in many situations globally, including ungulate damage to agricultural crops and fences, to livestock predation by carnivores (Wagner et al, 1997; Nyhus et al, 2005; Bauer et al, 2017). As the decline in resident attitudes is strongly associated with increased financial cost in repairing kākā damage, FCS may also be a viable option to mitigate the conflict in Wellington. Government, regional and private bodies can provide residents who have spent substantial financial resources repairing damage, with compensation relative to their expenditure. Compensation can work effectively for assets that have solely financial value e.g. agricultural crops. However, residential property damaged by kākā may also have sentimental value that goes 
beyond what can be financially covered. In these cases, compensation may not be as effective.

It can also be difficult to assess and quantify damage caused by kākā (Nyhus et al, 2005). Kākā damage to trees is distinctive, with lateral and transverse bark gouges that can be easy to recognise (Charles, 2012). Damage to trees then, can be straightforward to identify, monitor and if mortality occurs, tree removal can be financially compensated. However, damage to building surfaces may not be as simple to assess, nor compensate. This can be due to the varying degrees of damage, repair methods, and whether the damage was in fact, caused by kākā. The difficulty in finding agreeable compensation may cause disputes between stakeholders, further complicating the overall conflict.

Negative attitudes towards wildlife can be difficult to change (Manfredo et al, 2017). However, compensation schemes can act as a form of compromise to the affected residents, so that their attitudes do not deteriorate further. I recommend government and regional bodies initiate monitoring the damage to private property through resident reports and begin to explore options on how to best implement financial compensation.

\subsection{Further urban reintroductions of kākā}

A further step in advancing kākā conservation could explore whether this reintroduction of kākā into an urban environment can be replicated elsewhere in New Zealand. The success of this reintroduction in Wellington is based predominantly on the presence of the Karori Wildlife Sanctuary (KWS) and its surrounding anti-predator fence. The sanctuary also provides kākā with artificial feeding stations, supplying the birds with a sugar water mix and cereal pellets. However, this is currently the only fully fenced urban wildlife sanctuary in New Zealand. In the absence of such refugia in other urban environments, reintroduction may still be possible so long as predators are suppressed, and the birds have a reliable food source. 
Through seeking experts' opinions, van Heezik and Seddon (2018) identified kākā, among a list of other forest birds, as a species that has potential for reintroduction into urban environments. They also identify predation pressure, in the form of both domestic and pest mammal species, as a limiting factor in the success of urban reintroductions. Like a majority of New Zealand's native birds, kākā are susceptible to predation by small introduced mammals such as mustelids, rats and possums, particularly due to their use of secondary cavities as breeding sites (Wilson et al, 1998; Moorhouse et al, 2003). Extensive predator control through trapping and bait stations by residents and city councils will be required to help ease this pressure. Domestic cats also exert predation pressure on urban birdlife (Baker et al, 2005; van Heezik et al, 2010). However, they, along with domestic dogs, did not appear to influence kākā presence on properties in Wellington. While the direct impact that domestic cats have on kākā and breeding success is still unknown, this finding suggests that the impact is not as great as that of the invasive mammal species mentioned previously.

Artificial nest boxes have also been suggested to help the reintroduction of kākā, by acting as supplementary breeding locations (van Heezik and Seddon, 2018). Nest boxes with anti-predator mechanisms have been found to reduce predation and increase fledgling in both kākā and other forest birds (Stamp et al, 2002; Greene and Jones, 2003; Pitt et al, 2011). Introducing these nest boxes is likely to further improve breeding success. Breeding successfully is vital in establishing a population, particularly when the population is small (Lacy, 2000). This thesis and observations of feeding behaviour in KWS show that kākā are able to utilise anthropogenic food sources. Setting up artificial feeding stations in green spaces similar to those present in KWS, may further help reintroductions into urban environments as natural food may be scarcer than rural, forest environments. Providing kākā with the right nutrients in close proximity to nesting sites lowers the need to expend energy 
through other necessary behaviours such as foraging. It may also reduce the possibility of conflict with people if these feeders are located away from residential properties.

If carried out effectively, further reintroduction of kākā could be widely beneficial. It can serve to increase the overall population of an endangered species and provide urban residents everyday interaction with an iconic New Zealand species, thereby enhancing their appreciation and engagement with nature. However, this thesis and previous works document circumstances in which kākā behaviour can instigate conflict with residents (Charles, 2013; Charles and Linklater, 2015; Linklater et al, 2018). How potential conflict will be resolved should be considered when planning further reintroductions. Otherwise these conflicts and the resulting decline in attitudes will rise in other urban environments, with limited or costly means of resolution.

\subsection{Conclusion}

This thesis explored the interaction between kākā, the urban environment of Wellington City and the residents living within it. It focused on what factors affect kākā's use of the urban environment, what factors cause or exacerbate property damage and how this damage affects residents. Based on the findings, two main recommendations have been made; i) discouraging residential feeding and ii) exploring the viability of financial compensation schemes to assist affected residents. The conflict in Wellington's urban environment is complex, involving social, economic and ecological aspects that all must be addressed. While conflict between people and kākā in Wellington is certainly present, it is not yet widespread. However, it is likely that instances of conflict involving kākā and people will only grow as the kākā population within the city increases. It is hoped that the findings in this thesis can help inform conservation managers and the city council of the current state of the conflict, before it reaches a tipping point in which widespread negative attitudes will be difficult to resolve. 


\title{
Appendix One
}

\section{if \\ Research Project: \\ Kaka in Wellington City}

Dear Householder,

About a week from now, you will receive in your mailbox a request to fill out a short questionnaire for an important research project being carried out at Victoria University of Wellington. The purpose of this short questionnaire is to investigate the relationship between Wellington City residents and the native parrot, kaka and what factors influence the distribution of kaka in our city environment.

Kaka were first reintroduced to the Wellington region in 2002. Fourteen breeding pairs were reintroduced to Karori Wildlife Sanctuary (Zealandia) between 2002 and 2007. This was successful and kaka are now common in the city.

Wellington residents were surveyed for this purpose in 2012. We hope to update our understanding of the distribution of kaka in the city and residents' opinions and experience of kaka where they live.

Your household has been chosen randomly from those in suburbs around Zealandia, the wildlife sanctuary, to get a representative sample of Wellington residents where kaka are most common.

You are receiving this advance letter because we realise that many people like to be aware ahead of time that they will be asked to fill out a questionnaire. Your answers will be strictly confidential and anonymous. The results of the questionnaire will only be used for this study.

A report on this study will be made available to you on the Victoria University website when it is complete.

We thank you in advance for your time and cooperation with this research. It is only with the generous help of people like you that our research can be successful.

Yours sincerely,

Johan Gouws.

MSc student,

\author{
SCHOOL OF BIOLOGICAL SCIENCES \\ Te Kura Mātauranga Koiora \\ FACULTY OF SCIENCE \\ Te Wāhanga Pūtaiao \\ P.O. Box 600, Wellington, New Zealand \\ Telephone +64-4-463-5339, Facsimile +64-4-463-5331 \\ EmailBiosci@vuw.ac.nz
}




\section{Appendix Two}

VICTORIA UNIVERSITY OF WELLINGTON

Te Whare Wānanga o te Ūpoko o te Ika a Māui

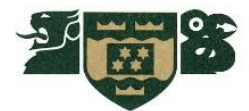

\section{Kaka in Wellington City Questionnaire Participant Information Sheet}

Dear Householder,

I am writing to ask your help in a study being conducted as part of my Master of Science at Victoria University. The aim of this study is to investigate how our native, endangered parrot, the kaka are using Wellington City's suburbs and the relationship they have with the city's residents. Results of this study will help us better understand what aspects of Wellington City are important to kaka and help improve the relationship between kaka and people in our city.

I am inviting you to participate in a short questionnaire that will take just 5 to 10 minutes to complete. Please read this Information Sheet before deciding whether or not to take part. If you decide to participate, thank you. If you decide not to take part, thank you for considering my request.

The information on the questionnaire is anonymous. This means that nobody, including any of the researchers, will know your identity. You will not be asked your name or other sensitive information. You are provided with a postage-paid (Freepost) return envelope so that you can send the completed questionnaire in anonymously. This research has been approved by the Victoria University Ethics Committee (Approval number 25242).

Collectively, the data from the questionnaires will be used as an important aspect of my Master's thesis. Following this, the data may also be used in the appropriate academic publications or conferences. All materials will be kept confidential and questionnaires will be destroyed five years after the end of the project. In March 2019, once the study is complete, findings of this study will be made available as part of my overall thesis to participants on the Victoria University website.

You may have been asked to fill out a similar questionnaire in October 2012. This seeks to build on those past results to give us an improved understanding of kaka behaviour and distribution in Wellington City and how this changes over time. I hope you will take a few minutes to help my research by completing the questionnaire.

If you have any other questions about this project, please feel free to contact me using the contact details provided below. If you have any concerns about the ethical conduct of the research you may contact the Victoria University HEC Convener: Associate Professor Susan Corbett. Email susan.corbett@vuw.ac.nz or telephone +64-4-463 5480.

Thank you very much for helping with this important study!

Yours sincerely, SCHOOL OF BIOLOGICAL SCIENCES

Te Kura Mātauranga Koiora

FACULTY OF SCIENCE

Johan Gouws

Te Wāhanga Pūtaiao

P.O. Box 600, Wellington, New Zealand

Telephone +64-4-463-5339, Facsimile +64-4-463-5331

Email Biosci@vuw.ac.nz 


\section{Appendix Three}

\section{Survey about Kaka in Wellington City}

1. How often do kaka visit your property?

(please tick one box)

$\square$ Never ------> go to question 10

$\square$ Once a year

$\square$ Once a month

$\square$ Once a week

$\square$ More than once a week

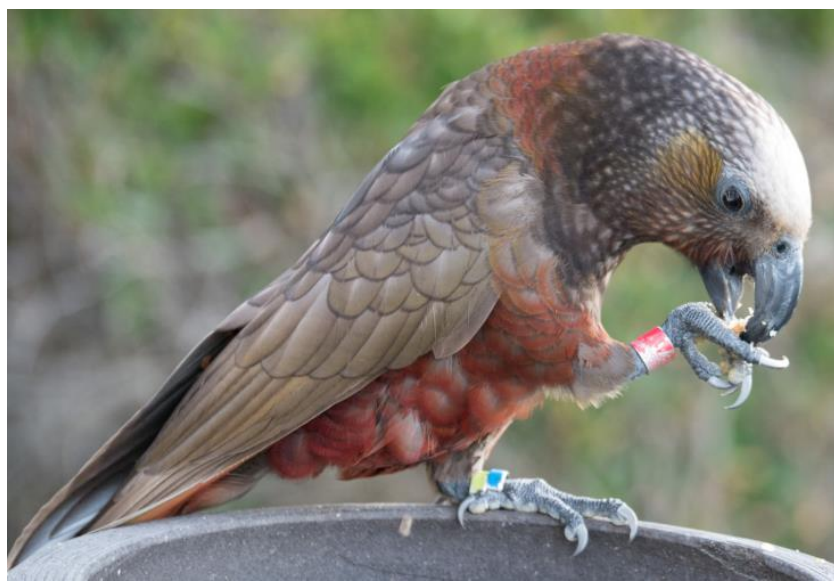

$\square$ More than once a day

2. What is the average number of kaka that you have seen visiting at any one time?
$\square 1$
$\square$ 2-3
4-6
7-9
$\square$ 10-15
more than 15

3. Do you feed kaka on your property? (please tick one box)
$\square$ No
---> go to question 5
$\square$ Yes

If yes, how often?

$\square$ Once a year

$\square$ Once a month

$\square$ Once a week

$\square$ More than once a week

More than once a day

4. What do you feed kaka? (Tick all that are applicable)

$\square$ Kitchen waste
$\square$ Fresh fruit and/or vegetables
$\square$ Nuts
$\square$ Seeds
$\square$ Bread
$\square$ Off the shelf bird food
$\square$ Other (please detail)


5. Do you think kaka have damaged your property in the last year?

$\square$ No -----> please go to question $10 \quad \square$ Yes ----> please got to the next question.

6. For each type of property, please circle a number from $\mathbf{0}$ (no damage) and 1 (minor damage) to 5 (major damage) to indicate the severity of the damage.

None---minor----------------------------- major

- Roofs, for example: nails, flashings, guttering. $\quad \begin{array}{llllllll}0 & 1 & 2 & 3 & 4 & 5\end{array}$ Please specify

- Other building surfaces, for example: walls, $\quad \begin{array}{lllllll}0 & 1 & 2 & 3 & 4 & 5\end{array}$ windows

Please specify:

- Trees

$\begin{array}{llllll}0 & 1 & 2 & 3 & 4 & 5\end{array}$

- Other (please specify):

$\begin{array}{llllll}0 & 1 & 2 & 3 & 4 & 5\end{array}$

7. Describe the damage in detail if you wish:

8. What, if anything, have you done to prevent or repair the damage by kaka on your property? (Please describe)

9. If so, what was the approximate cost (\$) of those preventions or repair of damage? 
10. Do you own a cat or dog? (Please tick all that apply)

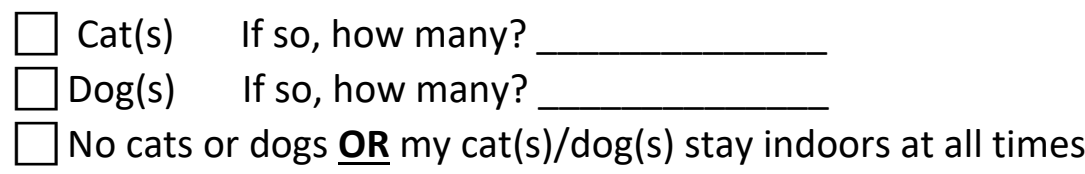

11. To what extent do you agree or disagree with the following statements: Circle a number for each statement from 1 to 5 where 1 indicates that you strongly disagree and 5 that you strongly agree.

\begin{tabular}{|c|c|c|c|c|c|}
\hline \multirow[b]{2}{*}{ Native birds are an asset for our city } & \multicolumn{5}{|c|}{ strongly----------neutral-------------strongly } \\
\hline & 1 & 2 & 3 & 4 & 5 \\
\hline $\begin{array}{l}\text { Native wildlife species deserve to be } \\
\text { protected }\end{array}$ & 1 & 2 & 3 & 4 & 5 \\
\hline $\begin{array}{l}\text { I enjoy seeing and/or hearing kaka in my } \\
\text { neighbourhood }\end{array}$ & 1 & 2 & 3 & 4 & 5 \\
\hline $\begin{array}{l}\text { Kaka have a right to live in our cities, } \\
\text { regardless of problems they may cause }\end{array}$ & 1 & 2 & 3 & 4 & 5 \\
\hline $\begin{array}{l}\text { I would like to see more kaka in my } \\
\text { neighbourhood }\end{array}$ & 1 & 2 & 3 & 4 & 5 \\
\hline $\begin{array}{l}\text { Kaka should be managed if they cause } \\
\text { problems }\end{array}$ & 1 & 2 & 3 & 4 & 5 \\
\hline $\begin{array}{l}\text { People should tolerate inconveniences } \\
\text { and minor damage caused by kaka }\end{array}$ & 1 & 2 & 3 & 4 & 5 \\
\hline
\end{tabular}

Please continue over the page 
Thank you for your answers on your experiences with kaka. We now have a few demographic questions that are used for statistical purposes only.

12. Are you the owner of this residence?

$\square$ No $\square$ Yes

13. Are you

$\square$ Male $\quad \square$ Female $\quad \square$ other

14. Are you

$\square$ Less than 18 years old

$\square 18-25$ years old

$\square 26-40$ years old

$\square 41-65$ years old

$\square$ over 65 years old

Thank you for your help. Return of this survey implies you have consented to participate in this study. Surveys can be returned in the envelope provided, or sent to: FreePost Kaka18, Dr. Wayne Linklater, School of Biological Sciences, Victoria University of Wellington, PO Box 600, Wellington 6140. 


\section{Appendix Four}

\section{Survey about Kaka in Wellington City}

1. How often do kaka visit your property? (please tick one box)

$\square$ Never ------> go to question 10

$\square$ Once a year

$\square$ Once a month

$\square$ Once a week

More than once a week

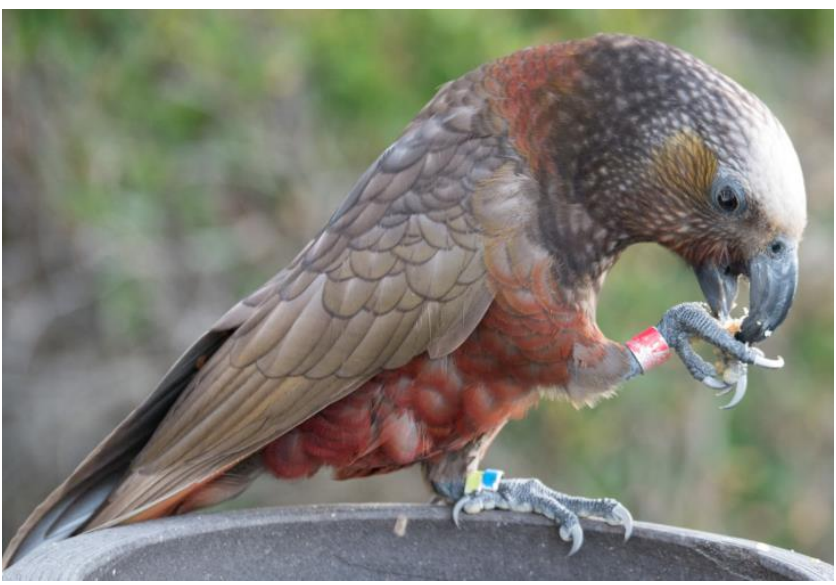

$\square$ More than once a day

2. What is the largest number of kaka that you have seen visiting at any one time?

$\square 1$

$\square$ 2-3

4-6

7-9

$\square$ 10-15

more than 15

3. Do you feed kaka on your property? (please tick one box)

$\square$ No $\quad$---> go to question $5 \quad \square$ Yes

If yes, how often?

Once a year

$\square$ Once a month

$\square$ Once a week

More than once a week

More than once a day

4. What do you feed kaka? (Tick all that are applicable)

$\square$ Kitchen waste
$\square$ Fresh fruit and/or vegetables
$\square$ Nuts
$\square$ Seeds
$\square$ Bread
$\square$ Off the shelf bird food
$\square$ Other (please detail)


5. Do you think kaka have damaged your property in the last year?

$\square$ No -----> please go to question $10 \quad \square$ Yes ----> please got to the next question.

6. For each type of property, please circle a number from $\mathbf{0}$ (no damage) and $\mathbf{1}$ (minor damage) to 5 (major damage) to indicate the severity of the damage.

None---minor-------------------------- major

- Roofs, for example: nails, flashings, guttering. $\quad \begin{array}{llllllll}0 & 1 & 2 & 3 & 4 & 5\end{array}$ Please specify

- Other building surfaces, for example: walls, $\quad \begin{array}{lllllll}0 & 1 & 2 & 3 & 4 & 5\end{array}$ windows

Please specify:

- Outdoor furniture

$\begin{array}{llllll}0 & 1 & 2 & 3 & 4 & 5\end{array}$

- Trees

$\begin{array}{llllll}0 & 1 & 2 & 3 & 4 & 5\end{array}$

- Vehicle

$\begin{array}{llllll}0 & 1 & 2 & 3 & 4 & 5\end{array}$

- Other (please specify):

$\begin{array}{llllll}0 & 1 & 2 & 3 & 4 & 5\end{array}$

7. Describe the damage in detail if you wish:

8. What, if anything, have you done to prevent or repair the damage by kaka on your property? (Please describe) 
9. And what was the approximate cost $(\$)$ of those preventions or repair of damage?

10. Do you have cats or dogs on your property? (Please tick all that apply)

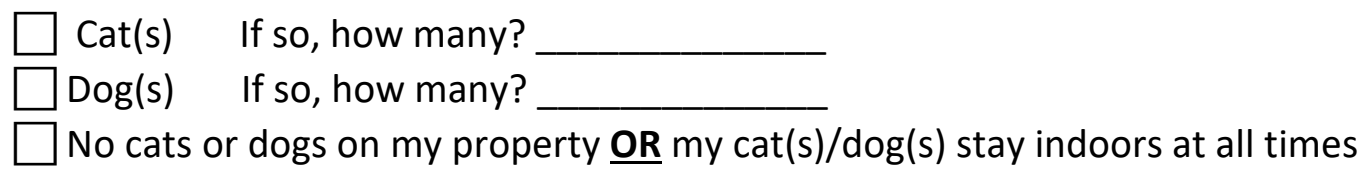

11. To what extent do you agree or disagree with the following statements: Circle a number for each statement from 1 to 5 where 1 indicates that you strongly agree and 5 that you strongly disagree.

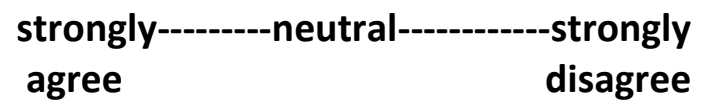

\begin{tabular}{|c|c|c|c|c|c|}
\hline Native birds are an asset for our city & 1 & 2 & 3 & 4 & 5 \\
\hline $\begin{array}{l}\text { Native wildlife species deserve to be } \\
\text { protected }\end{array}$ & 1 & 2 & 3 & 4 & 5 \\
\hline $\begin{array}{l}\text { I enjoy seeing and/or hearing kaka in my } \\
\text { neighbourhood }\end{array}$ & 1 & 2 & 3 & 4 & 5 \\
\hline $\begin{array}{l}\text { Kaka have a right to live in our cities, } \\
\text { regardless of problems they may cause }\end{array}$ & 1 & 2 & 3 & 4 & 5 \\
\hline $\begin{array}{l}\text { I would like to see more kaka in my } \\
\text { neighbourhood }\end{array}$ & 1 & 2 & 3 & 4 & 5 \\
\hline $\begin{array}{l}\text { Kaka should be managed if they cause } \\
\text { problems }\end{array}$ & 1 & 2 & 3 & 4 & 5 \\
\hline $\begin{array}{l}\text { People should tolerate inconveniences } \\
\text { and minor damage caused by kaka }\end{array}$ & 1 & 2 & 3 & 4 & 5 \\
\hline
\end{tabular}


Thank you for your answers on your experiences with kaka. We now have a few demographic questions that are used for statistical purposes only.

12. Are you the owner of this residence?

$\square$ No $\quad \square$ Yes

13. Are you

$\square$ Male $\square$ Female $\quad \square$ other

14. Are you

$\square$ Less than 18 years old

$\square$ 18-25 years old

$\square$ 26-40 years old

$\square$ 41-65 years old

$\square$ over 65 years old

Thank you for your help. Return of this survey implies you have consented to participate in this study. Surveys can be returned in the envelope provided, or sent to: FreePost Kaka, School of Biological Sciences, Victoria University of Wellington, PO Box 600, Wellington 6140. 


\section{Appendix Five}

VICTORIA UNIVERSITY OF WELLINGTON

Te Whare Wānanga o te Ūpoko o te Ika a Māui

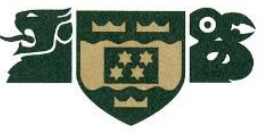

\section{Research Project \\ Kaka in Wellington City Questionnaire}

Dear Householder,

Recently a short questionnaire about our native parrot, the Kaka, in Wellington City was mailed to you. Your household was chosen due to its important location and being representative of city residents. As such, your participation in this survey is a valuable contribution to the study and questionnaires already received from your neighbours.

If you have already completed and returned the questionnaire, please accept our sincere thanks. If not, it would be much appreciated if you could complete and return your survey in the postage-paid envelope provided. If you have misplaced your survey, please contact me using the contact details provided below and I will provide a replacement copy.

Alternatively, you can complete the survey online. To do this go to https://goo.gl/V4dl21. The hard copy and on-line surveys are identical, please only complete one of them.

If kaka do not visit your property, please still fill it out the questionnaire. By doing this you are helping us estimate the distribution of kaka throughout the city and the reasons for it. Knowing properties that kaka do not visit is important to understanding their movements in the city.

I am especially grateful for your help because it is only by asking people like you to share your opinions and experiences that we can understand how people in Wellington interact with kaka and the value and challenges of wildlife in cities. The study is important as it will provide information to help improve the relationship between kaka and residents in our city.

Thank you very much for your help in my research!

Yours sincerely, Johan Gouws.

MSc student, Victoria University of Wellington.

\author{
SCHOOL OF BIOLOGICAL SCIENCES \\ Te Kura Mātauranga Koiora \\ FACULTY OF SCIENCE \\ Te Wāhanga Pūtaiao \\ P.O. Box 600, Wellington, New Zealand \\ Telephone +64-4-463-5339, Facsimile +64-4-463-5331 \\ EmailBiosci@vuw.ac.nz
}




\section{References}

Aguiar, L. M., Cardoso, R. M., Back, J. P., Carneiro, E. C., Suzin, A., \& Ottoni, E. B. (2014). Tool use in urban populations of capuchin monkeys Sapajus spp.(Primates: Cebidae). Zoologia (Curitiba), 31(5), 516-519.

Alberti, M. (2008). Advances in urban ecology: integrating humans and ecological processes in urban ecosystems (No. 574.5268 A4). New York: Springer.

Alterio, N. (2000). Controlling small mammal predators using sodium monofluoroacetate (1080) in bait stations along forestry roads in a New Zealand beech forest. New Zealand Journal of Ecology, 3-9.

Baker, P. J., Bentley, A. J., Ansell, R. J., \& Harris, S. (2005). Impact of predation by domestic cats (Felis catus) in an urban area. Mammal Review, 35(3-4), 302-312.

Baker, P. J., Molony, S. E., Stone, E., Cuthill, I. C., \& Harris, S. (2008). Cats about town: is predation by free-ranging pet cats (Felis catus) likely to affect urban bird populations? Ibis, 150, 86-99.

Bangs, E. E., Fontaine, J. A., Jimenez, M. D., Meier, T. J., Bradley, E. H., Niemeyer, C. C., \& Oakleaf, J. K. (2005). Managing wolf-human conflict in the northwestern United States. Conservation Biology Series- Cambridge, 9, 340.

Bangs, E., \& Shivik, J. A. (2001). Managing wolf conflict with livestock in the northwestern United States. Carnivore Damage Prevention News, 3, 2-5

Banks, P. B., \& Bryant, J. V. (2007). Four-legged friend or foe? Dog walking displaces native birds from natural areas. Biology letters, 3(6), 611-613.

Barton, K. (2018). MuMIn: Multi-Model Inference. R package version 1.42.1. https://CRAN.R-project.org/package=MuMIn

Bauer, H., Müller, L., Van Der Goes, D., \& Sillero-Zubiri, C. (2017). Financial compensation for damage to livestock by lions (Panthera leo) on community rangelands in Kenya. Oryx, 51(1), 106-114.

Beaven, B. M. (1996). Sap feeding behaviour of North Island kaka (Nestor meridionalis septentrionalis) in plantation forests (Doctoral dissertation, University of Waikato).

Beckmann, J. P., \& Berger, J. (2003). Rapid ecological and behavioural changes in carnivores: the responses of black bears (Ursus americanus) to altered food. Journal of Zoology, 261(2), 207-212.

Belant, J. L. (1997). Gulls in urban environments: landscape-level management to reduce conflict. Landscape and urban planning, 38(3-4), 245-258.

Bjerke, T., Østdahl, T., \& Kleiven, J. (2003). Attitudes and activities related to urban wildlife: Pet owners and non-owners. Anthrozoös, 16(3), 252-262.

Boone, H. N., \& Boone, D. A. (2012). Analyzing likert data. Journal of extension, 50(2), 1-5. 
Bongaarts, J. (2009). Human population growth and the demographic transition. Philosophical Transactions of the Royal Society B: Biological Sciences, 364(1532), 2985-2990.

Brockie, B. 'Native plants and animals - overview - Species unique to New Zealand', Te Ara the Encyclopaedia of New Zealand, http://www.TeAra.govt.nz/en/native-plants-andanimals-overview/page-1 (accessed 14 May 2019)

Bolund, P., \& Hunhammar, S. (1999). Ecosystem services in urban areas. Ecological economics, 29(2), 293-301.

Bozek, C. K., Prange, S., \& Gehrt, S. D. (2007). The influence of anthropogenic resources on multi-scale habitat selection by raccoons. Urban Ecosystems, 10(4), 413-425.

Burnham, K. P., \& Anderson, D. R. (2004). Multimodel inference: understanding AIC and BIC in model selection. Sociological methods \& research, 33(2), 261-304.

Cameron, R. W., Blanuša, T., Taylor, J. E., Salisbury, A., Halstead, A. J., Henricot, B., \& Thompson, K. (2012). The domestic garden-Its contribution to urban green infrastructure. Urban forestry \& urban greening, 11(2), 129-137.

Carter, A., Barr, S., Bond, C., Paske, G., Peters, D., \& van Dam, R. (2016). Controlling sympatric pest mammal populations in New Zealand with self-resetting, toxicant-free traps: a promising tool for invasive species management. Biological Invasions, 18(6), 1723-1736.

Charles, K. E. (2012). Tree damage in Wellington as a result of foraging for sap and barkdwelling invertebrates by the North Island kaka (Nestor meridionalis septentrionalis). Notornis, 59, 180-184.

Charles, K. E., \& Linklater, W. L. (2013). Dietary breadth as a predictor of potential native avian-human conflict in urban landscapes. Wildlife Research, 40(6), 482-489.

Charles, K. E., \& Linklater, W. L. (2014). Selection of trees for sap-foraging by a native New Zealand parrot, the Kaka (Nestor meridionalis), in an urban landscape. Emu-Austral Ornithology, 114(4), 317-325.

Chawla, L. (1999). Life paths into effective environmental action. The Journal of Environmental Education, 31(1), 15-26.

Clout, M. N., \& Lowe, S. J. (2000). Invasive species and environmental changes in New Zealand. Invasive species in a changing world, 369-383.

Cohen, J. E. (2003). Human population: the next half century. Science, 302(5648), 11721175 .

Conover, M. R. (2001). Resolving human-wildlife conflicts: the science of wildlife damage management. CRC press.

Cooper, A. B., \& Millspaugh, J. J. (1999). The application of discrete choice models to wildlife resource selection studies. Ecology, 80(2), 566-575.

Cox, D. T., \& Gaston, K. J. (2016). Urban bird feeding: connecting people with nature. PloS one, 11(7). 
Crist, E., Mora, C., \& Engelman, R. (2017). The interaction of human population, food production, and biodiversity protection. Science, 356(6335), 260-264.

Curtin, S. (2009). Wildlife tourism: The intangible, psychological benefits of human-wildlife encounters. Current Issues in Tourism, 12(5-6), 451-474.

Davis, A., Taylor, C. E., \& Major, R. E. (2012). Seasonal abundance and habitat use of Australian parrots in an urbanised landscape. Landscape and Urban Planning, 106(2), 191-198.

Davis, I. (1987). Safe shelter within unsafe cities: Disaster vulnerability and rapid urbanisation. In Open House International (pp. 5-15).

Diamond, J., \& Bond, A. B. (1999). Kea, bird of paradox: the evolution and behavior of a New Zealand parrot. University of California Press.

Diamond, J., Eason, D., Reid, C., \& Bond, A. B. (2006). Social play in kakapo (Strigops habroptilus) with comparisons to kea (Nestor notabilis) and kaka (Nestor meridionalis). Behaviour, 143(11), 1397.

Dickman, A. J. (2010). Complexities of conflict: the importance of considering social factors for effectively resolving human-wildlife conflict. Animal conservation, 13(5), 458-466.

Dillman, D. A., Phelps, G., Tortora, R., Swift, K., Kohrell, J., Berck, J., \& Messer, B. L. (2009). Response rate and measurement differences in mixed-mode surveys using mail, telephone, interactive voice response (IVR) and the Internet. Social science research, 38(1), 1-18.

Dilks, P., Willans, M., Pryde, M., \& Fraser, I. (2003). Large scale stoat control to protect mohua (Mohoua ochrocephala) and kaka (Nestor meridionalis) in the Eglinton Valley, Fiordland, New Zealand. New Zealand Journal of Ecology, 27(1), 1-9.

Ditchkoff, S. S., Saalfeld, S. T., \& Gibson, C. J. (2006). Animal behaviour in urban ecosystems: modifications due to human-induced stress. Urban ecosystems, 9(1), 5-12.

Duncan, R. P., \& Blackburn, T. M. (2004). Extinction and endemism in the New Zealand avifauna. Global Ecology and Biogeography, 13(6), 509-517.

Dunn, R. R., Gavin, M. C., Sanchez, M. C., \& Solomon, J. N. (2006). The pigeon paradox: dependence of global conservation on urban nature. Conservation biology, 20(6), 18141816.

Ewers, R. M., Kliskey, A. D., Walker, S., Rutledge, D., Harding, J. S., \& Didham, R. K. (2006). Past and future trajectories of forest loss in New Zealand. Biological Conservation, 133(3), 312-325.

Fleischer Jr, A. L., Bowman, R., \& Woolfenden, G. E. (2003). Variation in foraging behavior, diet, and time of breeding of Florida scrub-jays in suburban and wildland habitats. The Condor, 105(3), 515-527.

Fortin, D., Beyer, H. L., Boyce, M. S., Smith, D. W., Duchesne, T., \& Mao, J. S. (2005). Wolves influence elk movements: behavior shapes a trophic cascade in Yellowstone National Park. Ecology, 86(5), 1320-1330. 
Fox, J., Weisberg, S., Price, B., (2018). carData: Companion to Applied Regression Data Sets. R package version 3.0-2. https://CRAN.R-project.org/package=carData

Fritts, S. H., Bangs, E. E., Fontaine, J. A., Johnson, M. R., Phillips, M. K., Koch, E. D., \& Gunson, J. R. (1997). Planning and implementing a reintroduction of wolves to Yellowstone National Park and central Idaho. Restoration ecology, 5(1), 7-27.

Fuller, R. A., Warren, P. H., Armsworth, P. R., Barbosa, O., \& Gaston, K. J. (2008). Garden bird feeding predicts the structure of urban avian assemblages. Diversity and Distributions, 14(1), 131-137.

Galbraith, J. A., Beggs, J. R., Jones, D. N., \& Stanley, M. C. (2015). Supplementary feeding restructures urban bird communities. Proceedings of the National Academy of Sciences, 112(20), E2648-E2657.

Galbraith, J. A., Beggs, J. R., Jones, D. N., McNaughton, E. J., Krull, C. R., \& Stanley, M. C. (2014). Risks and drivers of wild bird feeding in urban areas of New Zealand. Biological Conservation, 180, 64-74.

Gaston, K. J., Warren, P. H., Thompson, K., \& Smith, R. M. (2005). Urban domestic gardens (IV): the extent of the resource and its associated features. Biodiversity \& Conservation, 14(14), 3327-3349.

Gelman, A., \& Hill, J. (2012). Data analysis using regression and multilevel hierarchical models (Vol. 1). New York, NY, USA: Cambridge University Press.

Gillies, C., \& Clout, M. (2003). The prey of domestic cats (Felis catus) in two suburbs of Auckland City, New Zealand. Journal of Zoology, 259(3), 309-315.

Gómez-Baggethun, E., \& Barton, D. N. (2013). Classifying and valuing ecosystem services for urban planning. Ecological Economics, 86, 235-245.

Greene, T. C., \& Jones, A. (2003). Observed responses of captive stoats (Mustela erminea) to nest boxes and metal collars used to protect kaka (Nestor meridionalis) nest cavities. New Zealand Journal of Ecology, 139-145.

Groom, C. J., Mawson, P. R., Roberts, J. D., \& Mitchell, N. J. (2014). Meeting an expanding human population's needs whilst conserving a threatened parrot species in an urban environment. WIT Transactions on Ecology and the Environment, 191, 1199-1212.

Gupta, A. C. (2013). Elephants, safety nets and agrarian culture: understanding humanwildlife conflict and rural livelihoods around Chobe National Park, Botswana. Journal of Political Ecology, 20(1), 238-254.

Hannon, E. R., \& Hafernik, J. E. (2007). Reintroduction of the rare damselfly Ischnura gemina (Odonata: Coenagrionidae) into an urban California park. Journal of insect conservation, 11(2), 141-149.

Hebblewhite, M., \& Merrill, E. (2008). Modelling wildlife-human relationships for social species with mixed-effects resource selection models. Journal of applied ecology, 45(3), 834-844.

Hedges, S., \& Gunaryadi, D. (2010). Reducing human-elephant conflict: do chillies help deter elephants from entering crop fields? Oryx, 44(1), 139-146. 
Henry, J. A., \& Dicks, S. E. (1987). Association of urban temperatures with land use and surface materials. Landscape and urban planning, 14, 21-29.

Holdaway, R. N., \& Jacomb, C. (2000). Rapid extinction of the moas (Aves:

Dinornithiformes): model, test, and implications. Science, 287(5461), 2250-2254. Biology, 18(4), 1239-1252.

Holdaway, R. N., Worthy, T. H., \& Tennyson, A. J. (2001). A working list of breeding bird species of the New Zealand region at first human contact. New Zealand journal of zoology, 28(2), 119-187.

Innes, J. (1994). Kaka Damage to Exotic Plantation Trees at Whirinaki Forest- A Preliminary Report. Landcare Research Contract Report LC9495/36.

IUCN 2019. The IUCN Red List of Threatened Species. Version 2019-1. http://www.iucnredlist.org. Downloaded on 21 March 2019.

Ives, C. D., Giusti, M., Fischer, J., Abson, D. J., Klaniecki, K., Dorninger, C. \& Raymond, C. M. (2017). Human-nature connection: a multidisciplinary review. Current Opinion in Environmental Sustainability, 26, 106-113.

Jarrett, M. I., \& Wilson, K. J. (1999). Seasonal and diurnal attendance of Kea (Nestor notabilis) at Halpin Creek rubbish dump, Arthur's Pass, New Zealand. Notornis, 46(2), 273-286.

Jepson, P. D., Deaville, R., Barber, J. L., Aguilar, À., Borrell, A., Murphy, S. \& Cunningham, A. A. (2016). PCB pollution continues to impact populations of orcas and other dolphins in European waters. Scientific reports, 6, 18573.

Jones, D. N., \& James Reynolds, S. (2008). Feeding birds in our towns and cities: a global research opportunity. Journal of avian biology, 39(3), 265-271.

Kikillus, K. H., Chambers, G. K., Farnworth, M. J., \& Hare, K. M. (2017). Research challenges and conservation implications for urban cat management in New Zealand. Pacific Conservation Biology, 23(1), 15-24.

Kollmuss, A., \& Agyeman, J. (2002). Mind the gap: why do people act environmentally and what are the barriers to pro-environmental behaviour? Environmental education research, 8(3), 239-260.

Lacy, R. C. (2000). Considering threats to the viability of small populations using individualbased models. Ecological Bulletins, 48, 39-51.

Linklater, W., Chapman, H., Gregor, A., Calder-Flynn, R., Gouws, J., Quigan, O. \& Ying, Y. (2018). Initiating a conflict with wildlife-the reintroduction and feeding of kākā, Wellington City, New Zealand. Pacific Conservation Biology, 24(4), 360-370.

Loepelt, J., Shaw, R. C., \& Burns, K. C. (2016). Can you teach an old parrot new tricks? Cognitive development in wild kaka (Nestor meridionalis). Proceedings of the Royal Society B: Biological Sciences, 283(1832), 20153056.

Loram, A., Tratalos, J., Warren, P. H., \& Gaston, K. J. (2007). Urban domestic gardens (X): the extent \& structure of the resource in five major cities. Landscape Ecology, 22(4), 601-615. 
Lowry, H., Lill, A., \& Wong, B. B. (2013). Behavioural responses of wildlife to urban environments. Biological reviews, 88(3), 537-549.

Madden, F., \& McQuinn, B. (2014). Conservation's blind spot: the case for conflict transformation in wildlife conservation. Biological Conservation, 178, 97-106.

Manfredo, M. J., Bruskotter, J. T., Teel, T. L., Fulton, D., Schwartz, S. H., Arlinghaus, R. \& Sullivan, L. (2017). Why social values cannot be changed for the sake of conservation. Conservation Biology, 31(4), 772-780.

Manfredo, M. J., \& Dayer, A. A. (2004). Concepts for exploring the social aspects of humanwildlife conflict in a global context. Human Dimensions of Wildlife, 9(4), 1-20.

Manly, B. F. L., McDonald, L., Thomas, D. L., McDonald, T. L., \& Erickson, W. P. (2007). Resource selection by animals: statistical design and analysis for field studies. Springer Science \& Business Media.

Mantyka-pringle, C. S., Martin, T. G., \& Rhodes, J. R. (2012). Interactions between climate and habitat loss effects on biodiversity: a systematic review and meta-analysis. Global Change Biology, 18(4), 1239-1252.

Marchini, S. (2014). Who's in conflict with whom? Human dimensions of the conflicts involving wildlife. In Applied ecology and human dimensions in biological conservation (pp. 189-209). Springer, Berlin, Heidelberg.

Marshall, K., White, R., \& Fischer, A. (2007). Conflicts between humans over wildlife management: on the diversity of stakeholder attitudes and implications for conflict management. Biodiversity and Conservation, 16(11), 3129-3146.

McIntyre, N. E., Rango, J., Fagan, W. F., \& Faeth, S. H. (2001). Ground arthropod community structure in a heterogeneous urban environment. Landscape and urban planning, 52(4), 257-274.

Messmer, T. A. (2000). The emergence of human-wildlife conflict management: turning challenges into opportunities. International Biodeterioration \& Biodegradation, 45(34), 97-102.

Meyer, W. B., \& Turner, B. L. (1992). Human population growth and global land-use/cover change. Annual review of ecology and systematics, 23(1), 39-61.

Miller, J. R. (2005). Biodiversity conservation and the extinction of experience. Trends in ecology \& evolution, 20(8), 430-434.

Ministry for the Environment \& Stats NZ (2018). New Zealand's Environmental Reporting Series: Our land 2018. Retrieved from www.mfe.govt.nz and www.stats.govt.nz.

Minnis, D. L., \& Peyton, R. B. (1995). Cultural carrying capacity: modelling a notion. Urban deer: a manageable resource, 19-34.

Miskelly, C., Empson, R., \& Wright, K. (2005). Forest birds recolonising Wellington. Notornis, 52(1), 21-26.

Moorhouse, R. J. (1997). The diet of the North Island kaka (Nestor meridionalis septentrionalis) on Kapiti Island. New Zealand Journal of Ecology, 141-152. 
Moorhouse, R., Greene, T., Dilks, P., Powlesland, R., Moran, L., Taylor, G. \& Fraser, I. (2003). Control of introduced mammalian predators improves kākā Nestor meridionalis breeding success: reversing the decline of a threatened New Zealand parrot. Biological Conservation, 110(1), 33-44.

Muhly, T. B., \& Musiani, M. (2009). Livestock depredation by wolves and the ranching economy in the Northwestern US. Ecological Economics, 68(8-9), 2439-2450.

Naughton-Treves, L., \& Treves, A. (2005). Socio-ecological factors shaping local support for wildlife: crop-raiding by elephants and other wildlife in Africa. Conservation Biology Series-Cambridge, 9, 252.

Nelson, A. A., Kauffman, M. J., Middleton, A. D., Jimenez, M. D., McWhirter, D. E., \& Gerow, K. (2016). Native prey distribution and migration mediates wolf (Canis lupus) predation on domestic livestock in the Greater Yellowstone Ecosystem. Canadian Journal of Zoology, 94(4), 291-299.

Newsome, T., \& van Eeden, L. (2017). The effects of food waste on wildlife and humans. Sustainability, 9(7), 1269.

Northrup, J. M., Hooten, M. B., Anderson, C. R., \& Wittemyer, G. (2013). Practical guidance on characterizing availability in resource selection functions under a use-availability design. Ecology, 94(7), 1456-1463.

Nyhus, P. J., Osofsky, S. A., Ferraro, P., Madden, F., \& Fischer, H. (2005). Bearing the costs of human-wildlife conflict: the challenges of compensation schemes. Conservation Biology Series-Cambridge, 9, 107.

O’Donnell, C. F., \& Dilks, P. J. (1989). Sap-feeding by the kaka (Nestor meridionalis) in South Westland, New Zealand. Notornis, 36(1), 65-71.

O’Donnell, C. F., \& Dilks, P. J. (1994). Foods and foraging of forest birds in temperate rainforest, South Westland, New Zealand. New Zealand Journal of Ecology, 18(2), 87107.

O'Donnell, C. F., \& Rasch, G. (1991). Conservation of kaka in New Zealand. In A review of status, threats, priorities for research and implications for management. Dep. Conserv., Wellington.

Ogra, M., \& Badola, R. (2008). Compensating human-wildlife conflict in protected area communities: ground-level perspectives from Uttarakhand, India. Human Ecology, 36(5), 717.

Parkes, J., \& Murphy, E. (2003). Management of introduced mammals in New Zealand. New Zealand Journal of Zoology, 30(4), 335-359.

Peterson, M. N., Birckhead, J. L., Leong, K., Peterson, M. J., \& Peterson, T. R. (2010). Rearticulating the myth of human-wildlife conflict. Conservation Letters, 3(2), 74-82.

Pickett, S. T., Cadenasso, M. L., Grove, J. M., Nilon, C. H., Pouyat, R. V., Zipperer, W. C., \& Costanza, R. (2001). Urban ecological systems: linking terrestrial ecological, physical, and socioeconomic components of metropolitan areas. Annual review of ecology and systematics, 32(1), 127-157. 
Pitt, W. C., Driscoll, L. C., \& VanderWerf, E. A. (2011). A rat-resistant artificial nest box for cavity-nesting birds. Human-Wildlife Interactions, 5(1), 100-105.

Powlesland, R. G., Greene, T. C., Dilks, P. J., Moorhouse, R. J., Moran, L. R., Taylor, G. E. \& August, A. C. (2009). Breeding biology of the New Zealand kaka (Nestor meridionalis)(Psittacidae: Nestorinae). Notornis, 56, 11-33.

R Core Team (2013). R: A language and environment for statistical computing. R Foundation for Statistical Computing, Vienna, Austria. URL http://www.R-project.org/.

Recio, M. R., Payne, K., \& Seddon, P. J. (2016). Emblematic forest dwellers reintroduced into cities: resource selection by translocated juvenile kaka. Current zoology, 62(1), 1522.

Redpath, S. M., Bhatia, S., \& Young, J. (2015). Tilting at wildlife: reconsidering humanwildlife conflict. Oryx, 49(2), 222-225.

Redpath, S. M., Young, J., Evely, A., Adams, W. M., Sutherland, W. J., Whitehouse, A., \& Gutierrez, R. J. (2013). Understanding and managing conservation conflicts. Trends in ecology \& evolution, 28(2), 100-109.

Reynolds, S. J., Galbraith, J. A., Smith, J. A., \& Jones, D. N. (2017). Garden bird feeding: insights and prospects from a north-south comparison of this global urban phenomenon. Frontiers in Ecology and Evolution, 5, 24.

Ripple, W. J., \& Beschta, R. L. (2003). Wolf reintroduction, predation risk, and cottonwood recovery in Yellowstone National Park. Forest Ecology and Management, 184(1-3), 299-313.

Robb, G. N., McDonald, R. A., Chamberlain, D. E., \& Bearhop, S. (2008). Food for thought: supplementary feeding as a driver of ecological change in avian populations. Frontiers in Ecology and the Environment, 6(9), 476-484.

Ruszczyk, A., \& Mellender de Araujo, A. (1992). Gradients in butterfly species diversity in an urban area in Brazil. Journal of the Lepidopterists' Society (USA). 46(4), 255-264.

Sasidharan, V., \& Thapa, B. (2004). Ethnicity and variations in wildlife concern: exploring the socio-structural and socio-psychological bases of wildlife values. In 4 th International urban wildlife symposium, eds., WW Shaw, LK Harris, and L. Vandruff (pp. 305-315).

Sax, D. F., \& Gaines, S. D. (2008). Species invasions and extinction: the future of native biodiversity on islands. Proceedings of the National Academy of Sciences, 105(1), 11490-11497.

Seddon, P. J., Armstrong, D. P., \& Maloney, R. F. (2007). Developing the science of reintroduction biology. Conservation biology, 21(2), 303-312.

Shawkey, M. D., Bowman, R., \& Woolfenden, G. E. (2004). Why is brood reduction in Florida scrub-jays higher in suburban than in wildland habitats? Canadian Journal of Zoology, 82(9), 1427-1435.

Simberloff, D. S. (1974). Equilibrium theory of island biogeography and ecology. Annual review of Ecology and Systematics, 5(1), 161-182. 
Smith, D. W., \& Bangs, E. E. (2009). Reintroduction of wolves to Yellowstone National Park: history, values, and ecosystem restoration. Reintroduction of top-order predators. Oxford: Wiley-Blackwell, 92-125.

Smith, D. W., Peterson, R. O., \& Houston, D. B. (2003). Yellowstone after wolves. BioScience, 53(4), 330-340.

Smith, R. M., Thompson, K., Hodgson, J. G., Warren, P. H., \& Gaston, K. J. (2006). Urban domestic gardens (IX): composition and richness of the vascular plant flora, and implications for native biodiversity. Biological conservation, 129(3), 312-322.

Soulsbury, C. D., \& White, P. C. (2016). Human-wildlife interactions in urban areas: a review of conflicts, benefits and opportunities. Wildlife research, 42(7), 541-553.

Stamp, R. K., Brunton, D. H., \& Walter, B. (2002). Artificial nest box use by the North Island saddleback: effects of nest box design and mite infestations on nest site selection and reproductive success. New Zealand Journal of Zoology, 29(4), 285-292.

StatsNZ. (2018). Population. Retrieved on 11/09/18, www.stats.govt.nz,

Tanner, T. (1980). Significant life experiences: A new research area in environmental education. The Journal of Environmental Education, 11(4), 20-24.

Temby, I. D. (2004). Silver Gulls: urban waste creates flying problems. Presented at Urban Wildlife: more than meets the eye, Mosman, NSW, Australia. Royal Zoological Society of New South Wales. 153-8.

United Nations, Department of Economic and Social Affairs, Population Division (2017). World Population Prospects: The 2017 Revision, retrieved 10/09/18.

van Heezik, Y. M., Dickinson, K. J., \& Freeman, C. (2012). Closing the gap: communicating to change gardening practices in support of native biodiversity in urban private gardens. Ecology and Society, 17(1).

van Heezik, Y., \& Seddon, P. J. (2018). Animal reintroductions in peopled landscapes: moving towards urban-based species restorations in New Zealand. Pacific Conservation Biology, 24(4), 349-359.

van Heezik, Y., Smyth, A., Adams, A., \& Gordon, J. (2010). Do domestic cats impose an unsustainable harvest on urban bird populations? Biological Conservation, 143(1), 121130.

Veitch, C. R., \& Clout, M. N. (2001). Human dimensions in the management of invasive species in New Zealand. The great reshuffling: Human dimensions of invasive alien species, 63-71.

Wagner, K. K., Schmidt, R. H., \& Conover, M. R. (1997). Compensation programs for wildlife damage in North America. USDA National Wildlife Research Center-Staff Publications, 829.

Wallis, G. P., \& Trewick, S. A. (2009). New Zealand phylogeography: evolution on a small continent. Molecular ecology, 18(17), 3548-3580. 
Whitburn, J., Linklater, W. L., \& Milfont, T. L. (2018). Exposure to urban nature and tree planting are related to pro-environmental behaviour via connection to nature, the use of nature for psychological restoration, and environmental attitudes. Environment and Behaviour, 0013916517751009.

Wilson, P. R., Karl, B. J., Toft, R. J., Beggs, J. R., \& Taylor, R. H. (1998). The role of introduced predators and competitors in the decline of kaka (Nestor meridionalis) populations in New Zealand. Biological conservation, 83(2), 175-185.

World Population Review [2019] Population. Accessed 03/05/2019. http://worldpopulationreview.com/

Yule, K. (2016). Tri-trophic interactions of a predator-parasite-host assemblage in New Zealand. (Doctoral dissertation, Victoria University of Wellington.) 